\title{
Fıkıh Usulü Yazımında ve Öğretiminde Yanlış Bir Ezber ve Düşündürdükleri: Mefkud Örneği
}

\author{
İbrahim Kâfi Dönmez
}

Bu makalede, fikıh usulü eserlerinde istishabın delil değeri incelenirken, "Hanefîler'e göre istishap mevcut hakların korunmasında ( $\left.\operatorname{def}^{\prime} i\right)$ geçerli bir delildir, fakat yeni hakların kazanılmasında (ispat) geçerli değildir; Şâfîiler'e göre ise her iki durumda geçerli bir delildir" şeklinde ifade edilen usul ihtilafının örneklendirilmesinde tekrar edilegelen bir yanlışlığa dikkat çekilerek bu durumun düşündürdükleri üzerinde durulmaktadır. Özellikle Hanefî usul eserleriyle yakın dönem fıkıh usulü ders kitaplarının birçoğunda ve bazı çağdaş bilimsel yayınlarda yaygın biçimde görülen bilgi şöyledir: Gerek Hanefîler'e gerekse Şafiîler’e göre mefkudun malları -mefkudun öldügü ortaya çıkmadan veya mahkemece ölümüne karar verilmeden öncemirasçıları arasında bölüştürülmez (İstishap def'ide hüccettir); fakat mefkudun bu durumu açıklık kazanıncaya kadar geçen süre içinde vefat eden yakınlarına mirasçı olup olamayacağı hususunda bu iki mezhep farklı görüşe sahiptir: Şâfiîler’e göre mirasçı olur (İstishap ispatta da hüccettir), Hanefîler'e göre mirasçı olamaz (İstishap ispatta hüccet değildir). Bu mezheplerin usul ve fürû kaynakları üzerinde yaptığ ${ }^{-}$ mız incelemeler ise her iki mezhebin, belirtilen durumda mefkud "Mirasçı olur" veya "Mirasçı olamaz" şeklinde bir sonuca varmayıp, durumu açıklık kazanıncaya kadar miras payının koruma altına alınması noktasında birleştiğini ortaya koymuştur. Ayrıca Hanefî fürû eserlerinde yaygın biçimde yer alan, "Mefkud kendi hakları konusunda sağ, başkalarının hakları konusunda ölü hükmündedir” şeklindeki kalıp ifadenin ikinci önermesinin bu yanlış ezberin pekişmesine katkı sağlamış olabileceği üzerinde de durulmuştur.

Anahtar Kelimeler: Mefkud, istishap, def ${ }^{\prime} i$, ispat, miras, mirasçı, vâris, miras bırakan, mûris, miras engelleri.

* Prof.Dr., İstanbul 29 Mayıs Üniversitesi İlahiyat Fakültesi, ORCID oooo-ooo2-4087-1316 ikdonmez@29mayis.edu.tr 


\section{Giriş}

"İstishap" bütüncül bir bakışla incelendiğinde, bu kapsamdaki istidlal yöntemi, ilke ve kaideler ile istishap türleri hakkında usulcüler tarafından yapılan tartışmalar ve değerlendirmeler bir yana, bu delilin "Şek ile yakîn zâil olmaz" temel düşüncesinde birleşen bir fikirler zincirinin ifadesi olduğu ve bunun fikha yansıyan ortak kesitinin "geçmişte sabit olan bir durumun -değiştiğine dair delil bulunmadıkça- varlığını koruduğuna hükmetme", kısaca "olanın olduğu hal üzere kaldığını varsayma" noktasında birleștiği söylenebilir. Bu araştırmada, bazı kavâid müelliflerince fıkhın bütününü kuşattı̆̆g ileri sürülen beş küllî kaideden biri olan bu ana ilkenin açılımları ve istishap delilinin türleri ile ilgilenmeksizin, genellikle fikıh usulü eserlerinde istishabın bir türü olarak sunulan "istishâbüll-hâl"in hüccet (delil) değeri incelenirken âdeta müteârife (aksiyom) haline gelmiş bir bilginin örneklendirilmesinde tekrar edilegelen bir yanlışlığa dikkat çekilerek bu durumun düşündürdükleri üzerinde durulmaktadır.

Söz konusu bilgi, -başka anlatımları da bulunmakla birlikte- genellikle şöyle ifade edilir: "İstishap Hanefîler'e göre sadece def'ide hüccettir, ispatta değildir; Şâfiîler'e göre ise hem def 'ide hem ispatta hüccettir." Bununla anlatılmak istenen şudur: İstishap, mevcut hakların, daha önce varlığı bilinen durumlara bağlı sonuçların korunmasında (def'i) iki tarafa göre de geçerli bir delildir; yenilerinin meydana gelmesinde, kazanılmasında ise (ispat) Hanefîler'e göre geçerli bir delil değildir. Özellikle Hanefî usul eserleriyle yakın dönem fikıh usulü ders kitaplarının birçoğunda bu iki mezhebin böyle bir tutuma sahip olmalarının fürû-i fıkıhtaki sonuçlarını göstermek için zikredilen örneklerin başında, yerleşim yerinden uzaklaşıp kaybolan ve sağ mı ölü mü olduğu bilinmeyen kişinin (mefkud) mûris (miras bırakan) ve vâris (mirasçı) olması meselesi yer alır. Bu meseledeki anlatımların özeti şudur: Gerek Hanefîler'e gerekse Şâfiîler'e göre mefkudun mallarına tereke hükmü uygulanmaz, yani mal varlığ 1 -mefkudun öldüğü ortaya çıkmadan veya mahkemece ölümüne karar verilmeden önce- mirasçlları arasında bölüştürülmez (İstishap def 'ide hüccettir); fakat mefkudun bu durumu açıklık kazanıncaya kadar geçen süre içinde vefat eden yakınlarına mirasçı olup olamayacağı hususunda bu iki mezhep farklı görüşe sahiptir: Şâfiîlere göre mirasçı olur (İstishap ispatta da hüccettir), Hanefîlere göre mirasçı olamaz (İstishap ispatta hüccet değildir).

İlginç olan husus, bu hüküm farklılığı ile ilgili açıklamaların zaman içinde (fıkıh usulü öğretiminde) iki mezhep arasındaki fürû-i fikha ilişkin ihtilafın bir örneği olmanın ötesinde az önce belirtilen usul ihtilafını simgeleyen bir

1 Mecelle-i Ahkâm-ı Adliyye, md. 4. 
anlatıma dönüşmüş olmasıdır. Ne var ki iyi bir inceleme neticesinde belirtilen örneğin, bir yandan fürû-i fikha ilişkin hükümler bakımından sağlıklı sayılamayacak bir anlatımla sunulmaya çalışıldığı, diğer yandan da bu iki mezhep arasındaki usulî görüş ayrılı̆̆ını yansıtmaya elverişli olmayan "zayıf bir halka" durumunda olduğu ve fikıh usulü yazımında ve öğretiminde "yanlış bir ezberin" asırlar boyu tekrar edilegeldiği kanaatine ulaşılmaktadır.

Makalede öncelikli olarak, fikıh usulü yazımında öne çıkan ve usul öğretiminde günümüzde de zihinlere nakşedilmekte olan mefkud örneğinin ilgili literatürde nasıl bir seyir izlediği ve anılan iki mezhepten her birinin istishap deliliyle (özellikle "istishâbü'l-hâl") ilgili fikirler zinciri bakımından güçlü bir halka işlevi görmesi şöyle dursun, aksine yanıltıcı bir rol oynadığ 1 gösterilmeye çalışılmıştır. Bu arada, belirli bir dönemden sonra Hanefî fürû eserlerinde yaygın biçimde yer alan, "Mefkud kendi hakları konusunda sağ, başkalarının hakları konusunda ölü hükmündedir” şeklindeki kalıp ifadenin bu yanlış ezberin pekişmesine katkı sağlamış olabileceği üzerinde durulmuştur. Fakat çalışmanın asıl amacı, bir fürû meselesiyle ilgili yanlış bilgi aktarımının ne kadar yaygın olduğuna dair tespit ışığında, fikıh/fikıh usulü yazımında ve öğretiminde karşılaşılan bazı metot sorunları ile bunların hukuk tefekkürünün gelişimi üzerindeki olumsuz etkilerine dikkat çekmektir. Fıkıh alanına vukufu ve değerli katkılarıyla tanınan bazı yazarların fikıh usulü ders kitabı yazarlarken, hatta bazılarının mefkud ile ilgili hükümleri fürû-i fikıh ve karşılaştırmalı fıkıh içerikli yayınlarında özel olarak ele alırlarken fikıh usulü öğretimindeki bu yanlış ezberin etkisinden kurtulamamış olmaları bizi böyle bir araştırmaya sevkeden âmillerden biri olduğu için, bu iki gruba dahil bazı yazarların çalışmaları -bu yönüyle- makalede ayrı birer başlık altında incelenmiştir.

\section{Konunun Sinırlandırılması}

Fıkıh terimi olarak mefkud "yerleşim yerinden uzaklaşıp kaybolan ve sağ mı ölü mü olduğu bilinmeyen kişı” yi ifade eder. ${ }^{2}$ Tanımlara mefkud ile ilgili farklı hususlar yansıtılabildiği gibi, özellikle Hanbelî fıkıh kitaplarında içinde kaybolduğu şartlar bakımından mefkudun iki türü olduğu belirtilerek tanım yapma yolu tercih edilir; fakat daha çok mefkudun zevcesi ve mal varlığı ile ilgili hükümleri etkilediği ve araştırmamızın konusu açısından özel bir öneme sahip bulunmadığı için bu ayırım üzerinde durulmayacaktır.

Mefkudun anlamı ve hükümleri konusunun ilk dönem fıkıh eserlerinden itibaren etraflı sayılabilecek ölçüde ele alındığı ve özellikle son dönemde bu

2 Rastlayabildiğimiz ilk tanım Şeybânîye aittir (bk. el-Asl, IX, 352). 
konuya ilişkin birçok bilimsel yayın yapıldığı görülmektedir. Gerek Hanefî gerekse Şâfiî mezheplerinin (hatta dört mezhebin) fürû-i fikıh eserleri incelendiğinde, ${ }^{3}$ mefkudun kayıplığı sırasında bir yakını vefat ederse -mûrisinin ölümü esnasında sağ olup olmadığı anlaşılıncaya kadar- mirasçı gibi düşünüleceği, ancak bunun hemen işleme konmayıp payının koruma altına alınacağı sonucuna varılmaktadır. Son tahlilde, bu noktada fakihler arasında ittifaka yakın bir fikir birliği bulunmasına rağmen, genel olarak Hanefî usul ve fürû eserlerinde ve çok sayıda yakın dönem yetkin fikıh ve usul yazarının yayınlarında (özellikle fıkıh usulü ders kitaplarında) Hanefîler’e göre mefkudun mirasçı olamayacağı, birçoğunda da istishap ile ilgili usul ihtilafının kolay anlaşılmasını sağlamak üzere, "Şâfiîler' in onu mirasçı saydığı ama Hanefîler’in mirasçı saymadığı”" yönünde bilgi verilmesi şaşırtıcıdır.

Özetle, makale "mefkudun, kayıplığı sırasında vefat eden yakınına mirasçı olup olamayacağı" meselesi ile sınırlı olup, mirasçı sayılmasına veya sayılmamasına, kendisi için ayrılacak malın koruma altına alınmasına ve yönetimine, -sağ veya ölü olduğunun anlaşılması veya ölümüne hükmedilmesi durumlarında- bu payın âkıbetine ilişkin hükümler ile mefkud hakkındaki diğer meseleler inceleme dışında tutulmuştur. Bu ifadenin tekrarına çokça ihtiyaç duyulacağı ve bağlamdan kolayca anlaşıldığı için "mirasçısı konumunda bulunduğu yakını" denmemiştir. Yine "mefkudun mirasla ilgili durumunun ne olacăğ" denmesi daha uygun olduğu halde meselenin ilgili eserlerde böyle ele alınması sebebiyle "mefkudun mirasçı olup olamayacağı" ifadesi tercih edilmiştir. İlgili literatürde geçen "lâ yerisü" ibaresi literal olarak "Mirasçı olmaz" anlamına gelmekle birlikte, bağlama göre kastedilen mâna ve bu konuda yapılan açıklamalar dikkate alınarak "Mirasçı olamaz" şeklinde çevrilmiştir.

Konumuza ışı tutması açısından özel bir önemi haiz olmaması itibariyle, fikıh eserlerinde "gaip" ve "mefkud" kavramlarının karşılaştırılması, mefkudun ölümüne hükmedilirken hangi şartlar içinde kaybolduğunun ayırt edilmesi, İslam öncesi Arap toplumunda ve diğer hukuk sistemlerinde gaiplik ile ilgili düzenlemeler vb. hususlar üzerinde de durulmayacaktır.

3 Hanefî ve Şâfiî usul ve fürû eserleri makalede ayrıntılı biçimde incelenecektir. Mâlikî fürû eserlerindeki konuya ilişkin açıklamalar için bk. İbn Şâs, İkdüll-cevâhir es-semîne, III, 454; Lahmî, et-Tebsıra, V, 2231-49; Karâfî, ez-Zehîre, XIII, 22-23; İbnü'l-Hâcib, el-Muhtasar, XVII, 511-13; Halîl b. İshak, el-Muhtasar, VIII, 609; İbn Abdüsselâm el-Hevvârî, Şerhu Câmiu’l-ümmehât, XVII, 511-13. Hanbelî fürû eserlerindeki konuya ilişkin açılklamalar için bk. İbn Kudâme, el-Muğnî, IX, 186-91; a.mlf., el-Kâfî̀, IV, 131-32; İbn Kudâme, eş-Şerhu'l-kebîr, VII, 143-46; Buhûtî, Keşşâfü̉l-kınâ', VII, 2249-52; bu görüşlere toplu bakış için bk. Bilmen, Hukukı İslâmiyye ve Istılahatı Fıkhiyye Kamusu, VII, 210-27.

4 Ali Haydar'ın, Risâle-i Mefkūd adlı eserinde, belirtilen hükmü bir yerde "Mirasçı olamaz", başka bir yerde "Mirasçı olmaz" şeklinde ifade ettiği görülmektedir (s. 5, 20). 
Aynı șekilde araştırma konumuzu teşkil eden fikhî mesele istishap delilinin işletilmesi bağlamında ele alınmakla birlikte, bu delilin mahiyeti, istishap türleri, hüccet değeri ve ilgili eserlerde yer alan mefkud örneğinin bu delil açısından değerlendirilmesine ilişkin görüşler ve tartışmalar incelememizin dışında tutulmuştur. Kısaca belirtmek gerekirse "def ' $\mathrm{i}$ ” kelimesiyle mevcut hakların/hükümlerin/daha önce varlığı bilinen maddi olgu veya durumlara bağlı sonuçların korunması, "ispat" kelimesiyle yeni hakların kazanılması/ yeni hükümlerin meydana gelmesi kastedilmekle birlikte, makalede sık kullanım zaruretiyle karşılaşıldığ 1 ve inceleme konumuz "mefkudun miras b1rakan ve mirasçı olması"yla sınırlı bulunduğu için, bu kelimelerin açılımları "mevcut hakların korunması" ve "yeni hakların kazanılması" şeklindeki anlatımlarla sınırlı tutulmuştur. Bilgi veya ifadenin nakledildiği eserlerde "def ' $i$ " ve "ispat" kelimeleri yerine (ilzam, icap, ibka, ref', nefiy gibi) başka kelimeler kullanılmış, yine "istishâbü’l-hâl” başka şekillerde ifade edilmiş olsa da, dikkatleri dağıtmamak için bunları ayrıca belirtmekten de sarfınazar edilmiştir. Mefkud örneği ilgili litaratürde genellikle hem mirasçı (vâris) hem de lehine muayyen bir mal vasiyet edilen kişi (mûsâ-leh, vasiyet lehtarı) üzerinden yürütüldügü için, ele alacağımız yanlış bilginin, "Mefkud Şâfiîler’e göre mirasçı ve vasiyet lehtarı olur, Hanefîler'e göre mirasçı ve vasiyet lehtarı olmaz" şeklinde sunulması ve işlenmesi mümkündür. Fakat bu önermelerin çok tekrar edilerek dikkatlerin dağılmaması için biz sadece mirasçılık durumunu esas alacağız.

Kurucu dönemin eserleri de dahil olmak üzere fikıh ve usul kitaplarında "mefkudun, kayıplığı sırasında vefat eden yakınına mirasçıllı̆ı" meselesi incelenirken, "vkf" kökünden türetilmiş ("vakf”, "tevkiff”, "yûkaf”, "tevakkuf”, "mevkuf” vb.) kelimeler içeren ibareleri, -öncelikli olarak onun payı üzerinde fiilen belirli bir kişinin mülkiyetinin söz konusu olamayacağı anlatılmak istendiğinden- "Payı askıya alınır, ayrılır, tutulur, ertelenir" vb. şekillerde de tercüme etmek mümkün olmakla birlikte, yazımızda -yapılan işin mahiyeti ve bazı eserlerde yapılan açıklamalar dikkate alınarak- daha çok "Koruma altına alınır" şeklinde bir tercüme tercih edilmiştir. Zira bu durumda mefkudun payına düşen mal varlığının korunması ve yönetimi için bir "kayyım"ın atanması söz konusudur. Günümüzde aile hukukunun konularından "vesayet" kurumu bünyesinde incelenen "kayyımlı" hükümleri ve belirtilen mal varlığının korunması ve yönetimi hakkında fikıh eserlerinde yer alan bilgiler/fikhî ihtilaflar da makalenin dışında tutulmuştur.

Makalede, ele alınan konuya 1şık tutması yönüyle öne çıkan Hanefî ve Şâfiî usul ve fürû eserlerindeki bilgiler esas alınmış; ancak gerektiği ölçüde Mâlikî ve Hanbelî mezheplerinin usul ve fürû kaynakları yanında fikıh 
literatürü kapsamına giren başka bazı türlere de başvurulmuştur. "Yakın Dönem Çalışmaları" denirken de tüketici bir inceleme yoluna girilmeyip konuyu özel olarak ele alan çalışmalardan seçmeler yapılmıştır. Gerek telif gerekse tercüme şeklinde olsun, ilgili Türkçe yayınların birçoğunda, bu yazıda ele alınan yanlış aktarımın tekrar edildiğine rastlanmakla birlikte, araştırmamızın amacı açısından özel bir katkı sağlamayacağı ve makale hacmini de aşmamak için bunlardan örnekler verme cihetine gidilmemiştir.

Üniversite eğitiminde "yardımcı ders kitabı" veya "ders materyali” kavramının kullanılması daha uygun olsa da, çalışmamızda, yakın dönem fikıh usulü ders materyallerinden, sık tekrar edildiği için ve yaygın kullanıma uyularak "ders kitabı" şeklinde söz edilmiştir. Kaldı ki bu çalışmaların birçoğu değişik İslam ülkelerinin ortaöğretim düzeyindeki okullarında ders kitabı görevi de görmektedir.

\section{Hanefî Fıkıh Usulü Eserlerinde Mefkudun Mirasçı Olacağı Görüşünün Şâfiî̀ye/Şâfiîler'e Nispet Edilmesine İlişkin Tespitler}

\subsection{Debûsî, Pezdevî ve Serahsî̀nin Usul Eserleri}

Yaptığımız incelemeler, Şâfiî̀ye/Şâfiîlere göre mefkudun -kayıplı̆̆ı sırasında ölen- yakınına mirasçı olacağ 1 , buna karşılık Hanefîler’e göre mirasçı olamayacağı yönündeki bilginin hareket noktasını Debûsînin (ö. 430/1039) Takvîmül-edille adlı eserinde yer alan bir ifadenin oluşturduğunu söylemeyi mümkün kılmaktadır. Şöyle ki: Debûsî anılan eserinde "istishâbü’l-hâl"in (mevcut duruma göre hüküm verme) dördüncü kısmı olarak ele aldığı "bir hükmün baştan ispatına yarayan istishâbü'l-hâl”'i açıklarken mefkud örneğine yer vermekte, asıl itibariyle mefkudun yaşadığı bilindiği için -öldügüne dair delil bulunana kadar- bu bilgiye tutunulacağını, aynı şekilde sahip olduğu mal varlığı üzerindeki mülkiyeti sabit olduğundan -ölümüne dair delil bulunana kadar- buna tutunulacağını; ama babasının mülkiyetinde olanlar ona ait olmadığı için babası öldüğünde bu mal üzerinde onun lehine mülkiyet hakkının sabit olmayacağını, zira var olan duruma tutunmanın babasının mülkünün onun lehine sabit olmamasını, aksine -sübut delili bulununcaya kadar- olduğu hal üzere kalmasını gerektireceğini ifade etmektedir. Daha sonra "Şâfiî alimlerinden biri/bir kısmı ("ba'du şüyûhi’̧̧-Şâfiiiyye") ${ }^{5}$ onu (istishâbü'l-hâli) mirasçılığın ispatı için hüccet kılmıştır” diyerek bu görüşü nazik bir üslupla eleştirmektedir. ${ }^{6} \mathrm{Bu}$ esnada görüş sahibinden tekil zamir

5 Bir yazma nüshada (Süleymaniye Ktp., Lâleli, nr. 690, vr. $225^{\mathrm{a}}$ ) ibare "ba'du şüyûhi'şŞâfiî" şeklindedir.

6 s. 401. 
ve tekil fiil sigası kullanarak ("lâkinnehû kāle bihî ...") söz etmesi "ba'd" kelimesiyle bir kişiyi kastettiğini düşündürmektedir.?

Pezdevî (ö. 482/1089), aynı konuyu incelerken Şâfiî̀ye göre istishâbü’l-hâlin ispatta da geçerli olduğunu, ama kendilerine göre ispatta hüccet olmayıp sadece def'ide hüccet olduğunu ifade etmektedir. ${ }^{8}$ Müellif daha sonra bu usulî görüş ayrıllğını gösteren değişik fürû meselelerine açıklamalı olarak yer vermekle birlikte mefkud örneğini bu şekilde ele almamakta, sadece "Delilsiz varlığının devamının sabit olmasına dair sözümüzün örneği mefkudun hayatıdır" diyerek değinmektedir. ${ }^{9}$

Serahsî (ö. 483/1090) mefkud örneğini zikrederek onun vâris olacağ 1 görüşünü Şâfiînnin bazı ashabına ("ba'du ashâbişs-Şafiî̀") nispet etmektedir. Onun da -Debûsî gibi- nazik bir üslupla bu görüşü ileri sürenin gerçek maksadına açıklık getirmeye çalıştığı görülmektedir. Fakat bu konudaki ifadeleri mefkudun mirasçı olmasının anlamıyla ilgili hukukî bir analiz mahiyetinde olup, mefkudun mirasçı olacağı görüşünü "bazı Şâfîiler'e" nispet ettiği açıktır. ${ }^{10}$

Sonuç olarak, ileri dönemlerdeki bazı usul müelliflerinin, özellikle istishap konusundaki tavır farklılıklarına değinirlerken "üç büyükler" ("el-fuhûlü’s-selâse") diye niteledikleri üç Hanefî usulcüden Debûsî ve Serahsînin mefkudun ölen yakınına mirasçı olacağı görüşünü "Şâfiî mezhebine" veya "Şâfiîler'e" nispet etmedikleri, Pezdevînin ise "Şâfiî̀ye göre" şeklinde bir tasrihte bulunsa bile bu ifadeyi istishâbü'l-hâle ilişkin usulî görüş bağlamında

7 Araştırmamızın amacı açısından özel bir önemi olmadığı ve ele aldığımız konudaki tespit ve değerlendirmeleri etkilemesi beklenmediği için, Debûsînin kimi veya kimleri kastettiği hususunda özel bir araştırma yapmayı gerekli görmedik. Bize ulaşmayan Debûsî öncesi eserlerde Şâfiîler'den bu görüşe sahip fakihin/fakihlerin bulunduğu bilgisi yer almış olabileceği gibi Debûsî ilim meclislerinde tedavül eden bilgilere dayalı olarak da bu ifadeyi kullanmış olabilir. Debûsînnin "Yine (alimlerimiz) şöyle demişlerdir: Mefkud mirasçı olamaz ve ona mirasçı olunmaz" şeklindeki ifadesiyle mefkud örneğini özel olarak ele aldığ̣, "Delilin Bulunmamasını Hüccet Sayma” ana başlığının girişinde, "Bazı fakihlere göre delilin bulunmaması hasmın iddiasını nefyetmek isteyen lehine hüccet teşkil etse de yeni bir hükmü ispat etmek isteyen lehine hüccet olmaz. Merhum babam bu görüsste idi ve bunu Irak meşayihinden aktarırd”" (Takvîmüll-edille, s. 319, 322) dediği göz önününde bulundurulduğunda, Şâfiî alimlerinden birine (veya birkaçına) nispet ettiği bu görüşü de babasından duymuş olması ihtimal dahilindedir. Ancak Debûsîye kadarki -görebildiğimiz- Şâfiî fikıh ve usul eserlerinde böyle bir görüşe rastlamamış olmamız onun bu bilgiye bir Şâfiî kitabından muttali olmuş olabileceği ihtimalini zayıflatmaktadır.

8 Kenzül-vusûl, IV, 660-63.

9 IV, 663-70, özellikle 668.

10 el-Usûl, II, 223-24. 
kullandığı ve bunu izah sadedinde mefkud örneğinden yararlanmadığı görülmektedir.

Hal böyle iken, bir süre sonra bazı Hanefî usul eserlerinde istishabın Hanefîler'e göre sadece def'ide, Şâfiîler'e göre ise hem def'ide hem ispatta hüccet sayıldığına ilişkin usul ihtilafını açıklamak üzere, Şâfiîlere göre mefkudun ölen yakınına vâris olacağı, Hanefîler'e göre ise vâris olamayacağı örneğinin verilmeye başlanması dikkat çekmektedir.

\subsection{Serahsî Sonrası Usul Eserleri}

Serahsî sonrası Hanefî usul eserlerinde: a) Mefkudun -kayıplı̆̆ı sırasında- ölen yakınına mirasçı olup olamayacağı örneğine yer vermemeyi tercih edenler, b) Bu örneği sadece Hanefîler'in yaklaşımını açıklamak için kullananlar, c) Bu örneğe hem Hanefîler'in hem Şâfiîler' in yaklaşımını karşılaştırmalı olarak göstermek için yer verenler bulunmaktadır. Aşağıda bu üç grupla ilgili tespitlere yer verilecektir.

\subsubsection{Mefkud Örneğine Yer Vermemeyi Tercih Edenler}

Mefkudun -kayıplığı sırasında ölen- yakınına mirasçı olup olamayacağı örneğine yer vermeyenlerin bu meselenin, "İstishâbü’l-hâl def'ide hüccettir, ama ispatta hüccet değildir" kuralını açıklamak için uygun bir örnek olmadığ gerekçesiyle bilinçli bir tercih yaptıkları veya başka bir mülahazaya dayandıkları düşünülebilir. Bunlar arasında Abdülazîz el-Buhârînnin (ö. 730/1330) tutumu önemli görünmektedir. Zira Pezdevînnin el-Usulüne yapılan şerhler içinde, etraflı ve doyurucu açılamalarıyla usul çevrelerinde büyük takdir gören Keş̧ü'l-esrâr isimli eserinde Abdülazîz el-Buhârî, istishâbü’l-hâlin Şâfiî̀ye göre hem def'ide hem ispatta hüccet olduğunu, kendilerine göre ise def'ide hüccet olmakla birlikte ispatta olmadığını belirttikten sonra, metinde yer alan yeteri kadar açı örnekleri geniş biçimde açıklama ihtiyacı duyduğu halde metinde geçen ama ayrıntısı verilmeyen mefkud örneğine hiç değinmemektedir. ${ }^{11} \mathrm{Bu}$ tutum, onun anılan örneği belirtilen ihtilafı açıklamak için uygun görmediği yönünde bilinçli bir tercihte bulunduğunu düşündürmektedir.

İstishâbü'l-hâlin hüccet değerini tartışırken, "Meşayihimizin 'İstishâbü'l-hâl def'ide hüccettir, ama ilzamda değildir' sözünün anlamı budur" demekle yetinen Üsmendîyi (ö. 552/1157), ${ }^{12}$ "Bize göre def'ide hüccet-

11 Keş̧ül-esrâr, IV, 661-70, özellikle 668-70.

12 Bezlün-nazar, s. 675. 
tir, ispatta değildir; Şâfiî̀ye göre ise her iki durumda hüccettir” deyip şüf'a örneğine yer verdiği halde mefkud örneğini zikretmeyen İbn Melek ${ }^{13}$ ve benzeri alimleri, yine istishabı "fâsit deliller" kapsamında inceleyip usulî açıdan görüş ayrılıklarını açıklarken Şâfiîye göre hem def'i hem ispatta, kendilerine (Hanefîler'e) göre ise sadece def'ide hüccet olduğunu belirtip tartışan, "essulh ale'l-inkâr" örneğine yer verdiği halde mefkud örneğine değinmeyen Molla Hüsrev'le (ö. 885/1480) ${ }^{14}$ bu esere yazılan belli başlı haşiyelerin müelliflerini ${ }^{15}$ de bu grupta değerlendirmek uygun olur.

\subsubsection{Mefkud Örneğini Sadece Hanefîler'in Yaklaşımını Açılamak İçin Kullananlar}

Mefkud örneğini sadece Hanefiler'in yaklaşımını açıklamak için kullananlar içinde görebildiğimiz ilk eser Alâeddin es-Semerkandînin (ö. 539/1144) Mîzânüll-usûl fî̀ netâici'l-ukūl (el-Muhtasar) adlı kitabı olup, müellif şöyle demektedir: “(İstishâbü’l-hâl) müteahhirîn fukahanın çoğunluğuna göre, kişinin kendisi hakkında olanın olduğu halde bırakılması hususunda amel edilmesi gereken bir hüccettir; fakat hasmı ilzam veya olmayan bir durumun ispatı hakkında hüccet olmaya elverişli değildir. (...) Mesela mefkudun hayatı (yaşadığına hükmedilmesi) böyledir; zâhir olan onun hayatının devamı yönünde olduğundan, olanın olduğu halde bırakılması için hüccet olmaya elverişlidir, ki bu sebeple onun malına mirasçı olunmaz. Fakat bu, olmayan bir durumun ispatı hakkında hüccet olmaya elverişli değildir, ki bu sebeple o yakınlarına mirasçı olamaz."16

Anılan örneği Alâeddin es-Semerkandî kadar açık biçimde ele almamakla birlikte, bu grupta düşünülebilecek diğer bir müellif Lâmişî (ö. 522/1128), "İstishâbü’l-hâl ile amelin gerekli olup olmadığ 1 ve şer'î hükümlerde hüccet sayılıp sayılmayacağı hususunda ihtilaf ettiler” başlığını taşıyan fasılda bu konuda farklı görüşler olduğunu belirtmekte, fakat görüş sahiplerinden ve hangi hükme ulaşıldığından söz etmeksizin, "mefkudun hayatı örneğinde olduğu gibi" şeklinde bir ibareye yer verip ardından şöyle bir nakilde bulunmaktadır: "Şeyh Ebû Mansûr el-Mâtürîdî (rahimehullah) Me'hazü’şş̧erâi'de ${ }^{17}$ 'O, hasma karşı bir hüccettir' demiştir.”'18

13 Şerhu'l-Menâr, s. 277-78.

14 Mirâtül-usûl, s. 496-99. Molla Hüsrev'in, Hâşiye alâtt-Telvîh adlı eserinde de mefkud örneğine değinmeme tutumunu benimsediği görülmektedir (III, 36-37).

15 Mesela İzmîrî, Hâşiye, II, 366-68; Tarsûsî, Hâşiye, s. 496-99.

16 s. 659-6o.

17 "Me'hazüßşş̧erâi" şeklinde harekelendiği için aynen aktardık.

18 Bk. Kitâb fî Usûli'l-fikh, s. 188-89. 
Pezdevînnin eserini şerhedenlerden Siğnâkī ile (ö. 714/1314) ${ }^{19}$ Bâbertîyi de $\left(\right.$ ö. 786/1384) ${ }^{20}$ bu grupta mütalaa etmek mümkündür. Zira onların da "mefkud" örneği ile ilgilenmekle birlikte bu meseledeki Hanefî-Şâfiî görüş ayrılığına değinmeyip, mefkudun ölen yakınına ait mal hususunda sağ kabul edilmemesinin gerekçesini açıkladıkları görülmektedir.

Yine, kitabın farklı kişilere nispet edilmesi ve telif tarihi konusuyla ilgilenmeksizin, mefkud örneğini ele alıp, "-Kayıplığ

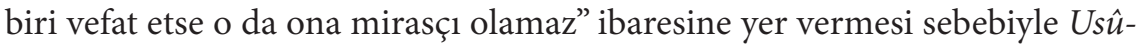
lüşs-Şâş̧ı̀nin ${ }^{21}$ de bu grupta yer aldığını belirtebiliriz.

Öte yandan, Hanefî muhitinde büyük ilgi gören Menârüll-envâr isimli eserine kendisinin yazdığı şerhte, istishabın Şâfiîye göre ispatta da hüccet sayılmasına mukabil kendilerine göre sadece def'ide hüccet sayıldığını belirttikten sonra, diğer örnekler üzerinde daha geniş durduğu halde mefkudun mirasçılığına kısaca değinip, "Babasına mirasçı olamaz" demekle yetinen Ebü'l-Berekât en-Nesefî̀yi (710/1310), ${ }^{22}$ bu esere yazdığ́ şerhte söz konusu görüş ayrılığının pratik sonucunu örneklerle açıklarken mefkud meselesinde Nesefîden bir adım öteye giderek, "Mefkud kendi malı konusunda sağ sayıldığı için ona mirasçı olunmaz, başkalarının malı konusunda ise ölü sayıldığı için de o mûrisinin malına vâris olamaz" diyen Molla Cîven’i (ö. 1130/1718); ${ }^{23}$ bu şerh üzerine yazdığ 1 haşiyede istishâbü'l-hâlin ispatta hüccet olmayacağına dair ibareyi, "Ki buna göre mûrisine vâris ve onun malına mâlik olmaz" şeklinde açıklayan Muhammed b. Abdülhalîm el-Leknevîyi de (ö. 1285/1868) ${ }^{24}$ Şâfiî̀ye mefkudun mirasçı olacağı görüusünü açık biçimde nispet etmemeleri yönüyle bu grupta zikretmek uygun olur.

Şu var ki bu gruptaki müelliflerin mefkudun -kayıplığı sırasında- ölen yakınına mirasçı olamayacağı görüşünü doğrudan olmasa da dolaylı olarak Şâfiîler'e nispet etmiş oldukları veya en azından usul öğretiminde gitgide yerleşen bu bilgiyi zımnî olarak pekiştirdikleri söylenebilir. Zira istishâbü'l-hâlin hüccet değeri konusundaki görüş ayrıllğının, "Hanefîler’e göre def'ide hüccettir, ama ispatta hüccet değildir; Şafiîler'e göre hem def'ide hem ispatta hüccettir" tarzında özetlendiği mukayese, fikıh literatüründe ve özellikle usul eserlerinde yaygın biçimde yer almaktadır, ki bu grupta zikredilenlerden bir kısmı bu karşılaştırmayı zaten kendileri de yapmaktadır.

19 el-Kâfî, IV, 1778-85; özellikle 1784-85.

20 et-Takrîr, VI, 154-69; özellikle 167.

21 Bk. Meys neşri, s. 388-89; Nedvî neşri, s. 266-69.

22 Keşfüll-esrâr, II, 268-70.

23 Şerhu Nûri'l-envâr, II, 269-70.

24 Kamerül-akmâr, II, 142. 
Bu örneğin Hanefîler'in miras hukukundaki görüşünü teyit için kullanılmasına gelince, "Mefkudun hayatı (yaşadığına hükmedilmesi) böyledir; zâhir olan onun hayatının devamı yönünde olduğundan, olanı olduğu halde bırakılması için hüccet olmaya elverişlidir, ki bu sebeple onun malına mirasçı olunmaz" şeklindeki izahın makul olduğu açıktır. "Fakat bu, olmayan bir durumun ispatı hakkında hüccet olmaya elverişli değildir, ki bu sebeple o yakınlarına mirasçı olamaz" şeklindeki izah miras hukuku ilke ve hükümleri ile bağdaşmadığı gibi vâkıaya da uygun değildir. ${ }^{25}$ Zira gerek Hanefî mezhebinde gerekse diğer meşhur üç mezhepte, mefkudun ölen yakınına mirasçı olamayacağ 1 hükmü benimsenmemiş, aksine hem sağ hem ölü olabileceği ihtimallerinin bulunduğu esasına göre çözüm arayışına girilmiş; bu durumdaki mefkudun miras payının koruma altına alınacağına, hatta bu payın mevcut mirasçllar tablosuna göre (İslam miras hukukundaki "hacb" kuralları çerçevesinde) mefkudun lehine olan şekle göre hesap edileceğine hükmedilmiştir.

\subsubsection{Mefkud Örneğine Hanefîler'in ve Şâfiîler'in Yaklaşımını Karşılaştırmalı Olarak Göstermek İçin Yer Verenler}

Bu gruptakiler araştırmamızın odak noktasını oluşturması itibariyle ayrı bir önemi haizdir. Bunları iki alt grup halinde incelemek uygun olur:

\section{A) Mefkudun Mirasçı Olacağı Görüşünü “Bazı Şâfiîler'e” Nispet Edenler}

Habbâzî (ö. 691/1292), kendilerine göre mefkudun yaşadığının bilinmesinin istishâbü'l-hâl yoluyla mülkünün olduğu durumda bırakılmasında hüccet olmaya elverişli sayıldığını, ama mûrisinin malında onun lehine mülkiyet ispatına elverişli bulunmadığını, buna karşılık bazı Şâfîiler’in mirasçılığın halefiyet olması itibariyle hükmün de varlığını koruyacağı gerekçesiyle bunu (mirasçı olmasını) tecviz ettiklerini belirtmektedir. ${ }^{26}$ Bu örnekte Debûsî ve Serahsînin etkisinin sürdüğü anlaşılmaktadır; zira müellif mefkudun ölen yakınına mirasçı olacağg görüşünü Şâfiî mezhebine değil bazı Şâfiî fakihlerine nispet etmekte ve bu durumu onlarınkine benzer biçimde açıklamaya çalışmaktadır.

Molla Fenârînin (ö. 834/1431) analitik ve eleştirel bakışını yansıtması yönüyle Osmanlı dönemi fikıh usulü eserleri içinde seçkin bir yere sahip olan Fusûlüll-bedâi' fì usûlişs-serâi' adlı eserde, "Bizim Fürûumuzdaki Diğer Bazı

25 Fürû eserleri incelenirken, bu tür anlatımlarda mefkudun fiilen miras payına mâlik olmayacağının kastedildiği hususu üzerinde durulacaktır.

26 el-Muğnî, s. 361. 
Örnekler" başlığı altında şöyle denmektedir: "Mefkud mekudluğuna hükmedilmeden önce ${ }^{27}$ ölene (yakınına) mirasçı olamaz ve kendisine de mirasçı olunmaz." ${ }^{28}$ Müellif belirtilen bağlamda Şâfiîler'in mefkudun mirasçılığı ile ilgili görüşüne değinmemekle birlikte, istishap türlerini gözden geçirirken, bir hükmün baştan ispatı için istishaba tutunmanın tamamıla hatalı olduğunu belirttikten sonra, "bazı Şâfiîler'in" bunu muteber saydıklarını ve bu delile dayanarak mefkudun mûrisine mirasçı olacağına hükmettiklerini belirtmekte; ardından da -Debûsî ve Serahsîdekine benzer biçimde- onların bu gerekçeye dayanarak tahriç yapmalarının hatalı olduğunu, zira bunun bir hükmün baştan ispatı yoluyla değil mefkudun hayatta olmasının hükmen bâki sayılması vasıtasıyla ulaşılan bir sonuç olduğunu ifade etmektedir. ${ }^{29}$

\section{B) Mefkudun Mirasçı Olacağı Görüşünü “Şâfiî̀ye” Nispet Edenler}

Ubeydullah b. Mes ûd Sadrüşşerîa (ö. 747/1346), fikıh usulü öğretiminde güçlü bir etkiye sahip olduğu bilinen (kendi yazdığı Tenkìhu'l-usûl’ün şerhi) et-Tavzîh isimli eserinde, istishabın Şâfiî̀ye göre bir delil ile sabit olup sonra devam edip etmediğinde şüphe bulunan her şeyde delil olduğunu, kendilerine (Hanefîler'e) göre def'ide hüccet olmakla birlikte ispatta hüccet olmadığını belirtmekte ve mefkud örneğine değinirken, "Mefkud ona göre mirasçı olur, bize göre mirasçı olamaz" diyerek bu görüşü Şâfiî̀ye nispet etmektedir. ${ }^{30}$ Bu eser üzerine et-Telvîh adıyla yazdığı haşiyede Teftâzânînin (ö. 792/1390), Sadrüşşerîảnın mefkudun yaşadığı bilgisini örnek verirken kullandığı, "bekasına dair delil bulunmayan durum hakkındaki görüşümüze ("kavlünâ") gelince" şeklindeki ifadesinin -hasmın sözü bununla ilgili olmadığı için- tutarlı olmadığını belirterek onu eleştirmekle birlikte, "31 "Mefkud ona (Şâfiî̀ye) göre mirasçı olur" tarzında verdiği bilginin yanlışlığına değinmemesi şaşırtıcıdır. Çünkü -daha çok- Şâfiî mezhebine mensup olduğu ileri sürülen, en azından bu mezhebe derin vukufuyla tanınan ${ }^{32}$ ve anılan esere birçok eleştiri yönelttiği bilinen Teftâzânînin bu duruma ses çıarmamak suretiyle inceleme konumuz olan yanlış bilginin perçinlenmesine dolaylı bir katkı sağladığı söylenebilir.

27 Bağlamdan ve ibarenin devamındaki açıklamadan "mefkudluğu sebebiyle ölümüne hükmedilmeden önce" mânasının kastedildiği anlaşılmaktadır.

28 II, 441-42.

29 II, 444.

30 II, 224-25.

31 II, 224-25.

32 Şafiî fikhının kolay ezberlenebilir bir üslupla özetlendiği Miftâhu’l-fikh (el-Miftâh, elMiftâh fî fürûi'l-fikhişs-Şâfî̀) isimli bir kitap telif etmiş olması (bk. Özen, "Teftâzânî", s. 306) bu hususun açık kanıtı sayılabilir. 
İbnü'l-Hümâm’n (ö. 861/1457) et-Tahrîr adlı usul eserindeki ifadeleri, istishabın hücciyeti konusundaki görüşlere ve ihtilafın dayandığı bakış açısı farklılıklarına özlü biçimde değinmesi ve -dakik bir inceleme (tahkik) sonunda ulaştığını belirttiği- kendi mezhebine aykırı olan kişisel kanaatini ortaya koyması itibariyle dikkat çekici olmakla birlikte, mefkudun mirasçı olması meselesinde verdiği bilginin tahkike dayalı olmadığı (bazı eserlerde öne çıkan bilginin aktarılmasından ibaret olduğu) görülmektedir. Bu eserde ve şerhinde (istishap konusundaki görüş ayrılığına bağlı olarak) Hanefîler'le Şâfiîler arasında fürû-i fikha ilişkin ihtilaflar ortaya çıktığı, mesela Şâfiî̀ye göre mefkudun -kaybolduğu dönemde- mûrislerinden vefat eden kimseye ${ }^{33}$ mirasçı olacağı, Hanefîlere göre ise mirasçı olamayacağ 1 açıkça ifade edilmektedir. ${ }^{34} \mathrm{Bu}$ ibare ile ilgili olarak İbn Nüceym tarafından yapılan önemli bir tespite -tekrardan kaçınmak üzere- makalenin sonuçlar ve değerlendirmeler içeren (8.) nolu başlığı altında değinilecektir.

Kirmastî de (ö. 900/1494), "Mefkud O’na (Şâfiîye) göre vâris olur, bize göre olmaz" diyerek bu görüşü doğrudan Şâfiîye nispet etmektedir. ${ }^{35}$

Yine Bahrülulûm el-Leknevî (ö. 1225/1810), Muhibbullah İbn Abdüşşekûr el-Bihârînin (ö. 1119/1707) Müsellemü’s-sübût'una yazdığı Fevâtihu'r-rahamût isimli şerhte, söz konusu usul ihtilafının pratik sonuçlarını açıklarken, "Şâfiî̀ye göre mefkud, -kayıp olduktan sonra- vefat eden yakınına mirasçı olur; zira onun daha önce yaşadığı biliniyordu, öyleyse şimdi de istishâbü'l-hâle göre sağ olduğuna hükmedilir; bize göre ise bu durumda mefkud mirasçı olamaz, çünkü şu anda yaşadığı bilinmemektedir ve bu durumda istishap hüccet değildir" diyerek bu görüşü Şâfiî̀ye nispet etmektedir. $^{36}$

\section{Hanefî Fürû-i Fıkıh Eserlerinde Mefkudun Mirasçılığı Meselesi}

Şeybânînnin (ö. 189/805), el-Asl’’n müstakil bir bölümünde mefkud ile ilgili hükümlere geniş biçimde yer verdiğ $i^{37}$ ve bu bölüm içinde ayrı bir başlık (bab) açıp mefkudun mirasçı olup olamayacağı meselesini değişik örnek

33 İbn Emîru Hâc (ö. 879/1474) tarafından bu eser üzerine yazılan et-Takrîr ve’t-tahbîr adlı şerhte "mûrislerinden" diye çevirdiğimiz ibare "min veresetihî" (vârislerinden) şeklindedir; ama bunun matbaa hatası olduğu anlaşılmaktadır. Emîr Pâdişah (ö. 987/1579) tarafından Teysîrüt-tahrîr adıyla yazılan şerhte bu ibare "mimmen yerisühû" (kendisine mirasçı olacağı kimselerden) şeklindedir.

34 III, 290-91.

35 Zübdetü’l-vüsûl, s. 165.

36 II, 359.

37 IX, 350-63. 
olaylar ışığıında ele aldığı görülmektedir. ${ }^{38}$ Sonraki dönemlerin eserlerinde, Şeybânîden bu mesele ile ilgili nakil yapılırken, bu babdaki ilk örnek olayın öne çıkarıldığı ve bunun eksik veya yanlış anlaşılmalarda etkili olduğu söylenebilir. Şöyle ki: Anılan başlıkta ele alınan ilk örnek olay, mefkudun da vârisleri arasında olduğu mûrise ait malın diğer vârislerin zilyetliğinde bulunması durumunda, -şayet mefkudun çocuklarıyla malı eli bulunduranlar arasında onun kayıplığı hususunda ihtilaf da yoksa- taraflar kadıya başvurduğunda ne yapılacağı ile ilgilidir. Şeybânî bu durumda malın yerinden oynatılmaması gerektiğini ve -mirasçı olup olamayacağı bilinmediğine ve kendisine ait olduğu bilinen bir mal söz konusu olmadığına göre- mefkud için bir payın ayrılıp koruma altına alınmayacağını belirtmektedir. ${ }^{39}$

Dikkatli bir inceleme yapıldığında farkedilmektedir ki, gerek bu gerekse devamındaki bazı örnek olaylarda Şeybânî, zilyetlikle veya ispat hukukuyla ilintili sorunlar söz konusu olunca pay ayrılmamasından söz etmekte; ama mefkudun mirasçı olamayacağı veya onun hiçbir şekilde payının koruma altına alınması gerekmediği gibi bir ifadesine, hele ileriki dönemlerde Hanefî fikı eserlerinde yaygın hale gelen, "Mefkud başkalarının hakları konusunda ölü hükmündedir" anlamını içeren bir sözüne rastlanmamaktadır. Aksine defalarca, "Sağ mıdır ölü müdür, mirasçı mıdır değil midir bilemem” şeklinde gerçekçi bir değerlendirme yapmakta ve mirasçı sayılıp sayılmayacağının sağ olup olmadığının açıklığa kavuşmasıyla kesinlik kazanacağını belirtmektedir. Daha önemlisi, zilyetlikle veya ispat hukukuyla ilintili sorunların söz konusu olmadığı ve "diğer mirasçıların taksim talep ettiği” örnek olaylarda açık biçimde, mevcut mirasçıların payının (İslam miras hukukundaki hacb kuralları çerçevesinde mefkudun sağ ve ölü olması ihtimallerinden hareketle yapılacak hesaplamaya göre) iki paydan daha az olan ("ekallü’n-nasîbeyn") kriteri esas alınarak kendilerine verileceğini, kalanın (mefkudun çıkıp gelmesi durumunda alacağı payın) ya malı zilyetliğinde bulunduranların elinde bırakılacağını veya bir yediemine tevdi edileceğini ("yûkafü’n-nısfü alâ yedey adlin") söylemektedir. ${ }^{40}$

38 IX, 360-63.

$39 \mathrm{IX}, 360$.

40 IX, 360-63. İbn Kudâme, vârisleri arasında mefkudun da bulunduğu bir kimsenin ölmesi olayı ile ilgili olarak cumhurun görüşünü açıkladıktan sonra, birini "bazı Şâfiîler demiştir ki (...)", diğerini "Muhammed b. Hasan demiştir ki” diyerek iki farklı görüşe değinmekte, Şeybânînin görüşünü açıklarken, "Muhammed b. Hasan 'söz, mal elinde bulunanın sözüdür' demiştir” şeklinde bir nakilde bulunup ardından yukarıda belirtilen zilyetlikle ilgili ilk örneği -yakın ifadelerle- aktarmakta, anlatımın sonunda "Cumhur birinci görüş üzeredir” demek suretiyle onun cumhurdan farklı bir görüşe sahip olduğu izlenimini vermiş olmaktadır (el-Muğnî, IX, 189); oysa burada Şeybânînin ifadelerine dayanarak verdiği bilgiler mefkudun mirasçı olup olmayacağı ve normal 
Tahâvî (ö. 321/933) incelediğimiz mesele hakkında şu açıklamayı yapmaktadır: "Bir kimse vefat ettiğinde geride iki kızı ve -ne durumda olduğu bilinmeyen mefkud- oğulun oğlu varsa kadı onun terekesini muhafaza edecek bir kişinin zilyetliğine verir. Şayet iki kızı ondan kendi miras paylarını vermesini isterlerse kadı onlara terekenin yarısını verir. Çünkü bilinmez, belki mefkud hayattadır ve onlarla birlikte mirasçı olur; aynı şekilde bilinmez, belki babasından önce ölmüştür; o sebeple iki kıza muhtemel iki duruma göre daha az olan payı verir, ki bu terekenin yarısıdır. Babalarının terekesinden kalan kısmı, mefkud olan oğlunun durumu anlaşılıncaya kadar koruma altına alır." ${ }^{41}$ Görüldüğü üzere Tahâvî, -Şeybânînin zikrettiği ilk örnek olaydan hareket ettiği için zilyetlik sorunuyla iç içe bir anlatımda bulunmuş olsa bile- Hanefî mezhebinin konuya ilişkin görüşünü sağlıklı biçimde yansıtmaya özen göstermiş; mefkudun hayatta olup olmadığı belli olmadığı sürece ona ölü veya sağ muamelesi yapılmayıp -çıkıp gelebileceği ihtimaline binaen- kendisi için uygun olan payın ayrılacağını ifade etmiştir.

Kerhînin (ö. 340/952) el-Muhtasar’ı müstakil olarak değil Kudûrînin şerhiyle birlikte (Şerhu Muhtasari'l-Kudûrî) günümüze intikal etmiş olsa da, mefkudun mirasçllığı meselesini nasıl ele aldığının tespit edilmesi bu konudaki değerlendirmelerimize katkı sağlayabilirdi. Ancak araştırmacılar tarafından bu eserde "Mefkud" ve "Ferâiz" bahislerinin yer almadığ belirtildiği için ${ }^{42}$ sadece "Siyer" bölümü tahkik edilmiş olup diğer kısımları halen yazma olarak bulunan bu hacimli eseri ${ }^{43}$ özel olarak incelemekten sarfınazar ettiğimizi belirtmeliyiz.

Debûsînnin (ö. 430/1039) fürû eseri olan el-Esrâr'ın "Kitâbü'l-Mefkūd" bölümünde sadece, mefkudun muhtaç durumdaki babasının onun mallarını satıp satamayacağı meselesinden hareketle kısa açıklamalar yer almakta, ${ }^{44}$ "Kitâbü'l-Ferâiz ve'l-mevârîs" bölümünde ise araştırma konumuz olan meseleye değinilmemektedir. ${ }^{45}$

şartlarda (mûrisine ait mallar mevcut mirasçılar arasında taksim edilirken) kendisinin payının ayrılıp ayrılmayacağına ilişkin bir görüş ayrılığı içermemekte, zilyetlik ve ispat hukukuyla ilgili meseleler ele alınmaktadır.

41 el-Muhtasar, s. 405.

42 Ençakar, "Hanefî Fıkıh Literatüründe Gelenek Oluşturan Kayıp Bir Metin”, s. 13-14.

43 Bu konuda bilgi için bk. Güney, Kudûrînin Şerhu Muhtasaril-Kerhî Adlı Eserinin "Siyer" Bölümünün Edisyon Kritiği .

44 II, 983 .

45 II, 712-14. Buna karşılık Debûsînin, usul eseri olan Takvîmü'l-edille'de Hanefî alimlerine nispet ederek "Mefkud mirasçı olamaz" ibaresini kullandığı görülmektedir (s. 76, 322). 
İncelediğimiz mesele bakımından özel önemi haiz bulunan Kudûrînin (ö. 428/1037) el-Muhtasar'ında ise "Mefkud, kayıplığı sırasında vefat eden hiç kimseye mirasçı olamaz" ifadesiyle yetinildiği görülmektedir. ${ }^{46}$

Tuhfetü'l-fukahầnın mukaddimesinde bunu yazma gerekçesini açıklarken, Şeyh Ebü'l-Hüseyin el-Kudûrînin el-Muhtasar’’ hakkında bazı övgü ifadeleri kullandıktan sonra, "Fakihlerin bu kitaba rağbeti yaygınlaşınca bazı dostlar benden musannifin eksik bıraktığı bir kısım meseleleri zikretmemi ve bunlarla ilgili müşkilleri açıklamamı (...) istediler" diyen Alâeddin es-Semerkandî (ö. 539/1144), ${ }^{47}$ "Kitâbü’l-Mefkūd"da, mefkudun akrabalarından biri vefat ettiğinde ona mirasçı olamayacağını söylemekle birlikte, kadının mefkudun payını ölünün terekesinden alıp onun adına ("ale'l-mefkūd") koruma altına almayacağını, fakat durumu açıklığa kavuşuncaya kadar (sahibi belli olmayan mal gibi) koruma altına alacağını belirterek bu bilgiye açıklık getirmektedir. $^{48}$

Ne var ki gerek bu açılamanın gerekse müteakip dönemlerdeki eserlerde bu yönde verilen bilgilerin yaygın olarak bilinen Kudûrî şerhlerine yansımadığı görülmektedir. Mesela Kudûrînin el-Muhtasar’ının önemli şerhlerinden olan Haddâd’’n (ö. 800/1398) el-Cevheretün-neyyire'sinde, Kudûrînin, "Mefkud, kayıplığı sırasında vefat eden hiç kimseye mirasçı olamaz" ifadesini açıklarken, "başkalarının hakları konusunda ölü (hükmünde) olduğu için" şeklindeki yaygın kalıbı kullanmakta; mefkudun payının koruma altına alınmasından ise söz etmemektedir. ${ }^{49}$ Yine bu eserin yaygın şerhlerinden olan Meydânînin (ö. 1298/1881) el-Lübâb’inda da Kudûrînin, "Mefkud, kayıplı̆̆ 1 sırasında vefat eden hiç kimseye mirasçı olamaz" ifadesi açılanırken -mefkud için pay ayrılacağına dair bir bilgi konmaksızın- "hayatta olduğu kesin olarak bilinmediği için" denerek hükmün gerekçesine değinilmiş ve

46 II, 217. Eserin "Kitâbü’l-Ferâiz" bölümünde de bu konuda başkaca bir açılama bulunmamaktadır (bk. IV, 186-99).

47 I, 5 (Matbaa hatası olarak I. cildin kapağına "II. cilt" yazılmıştır; öte yandan bu bilgi aynı eserin Dımaşk baskısından da teyit edilmiştir [bk. I, 1]). Alâeddin es-Semerkandînin Tuhfetü'l-fukahâ’yı Kudûrînin değil de Kerhînnin el-Muhtasar'ını esas alarak telif ettiği görüşü için bk. Ençakar, Kerhînin Muhtasar'mın Hanefî Muhtasar Geleneğine Etkisi, s. 21-24; a.mlf., "Hanefî Fıkıh Literatüründe Gelenek Oluşturan Kayıp Bir Metin", s. 11.

48 III, 350 .

49 IV, 212. Haddâd’ın, Hûcendîden "Mefkud başkalarının hakları konusunda sağ, kendi hakları konusunda ölü (hükmündedir)” şeklinde bir nakilde bulunup dolaylı bir anlatımla burada aynı sonuçların yani ona mirasçı olunamayacağı gibi onun da başkasına mirasçı olamayacağının kastedildiği açıklamasını yapmaya yer ayırabildiği halde, asıl ihtiyaç olan bilgiye değinmemesi (IV, 208) şaşırtıcıdır. 
ardından, "Mûrisin ölmüş ve mirasçının hayatta olması mirasçllı̆ıı şartıdır" bilgisi verilmiştir. ${ }^{50}$

Buna karşılık İbrâhim el-Halebînnin (ö. 956/1549) Osmanlı hukuk tatbikatında ve medrese eğitiminde ağırlıklı bir yere sahip olduğu bilinen Mülteka'l-ebhur adlı eseri ile Şeyhîzâde (Dâmâd) (ö. 1078/1667) tarafından bu esere Mecmau'l-enhur adıyla yazılan şerhte Kudûrînin maksadını açıklığa kavuşturma açısından başarılı bir sunumun yer aldığını belirtmek gerekir. Mültekā’daki ifade şöyledir: ${ }^{51}$ "(Mefkud) -şayet ölümüne hükmedilmişse- ${ }^{52}$ kayıplığı esnasında ölene mirasçı olamaz. Ölümüne hükmedilinceye kadar onun terekesinden kendine düşen pay -tamamı veya bir kısmı olmak üzere- koruma altına alınır. Ölümüne hükmedilmeden gelirse o pay onundur (...)." Mecmau'l-enhur'da da "şayet ölümüne hükmedilmişse" ibaresi, "(Musannıf) onun mutlak olarak mirasçı olamayacağını değil, şayet daha sonra ölümüne hükmedilmişse mirasçı olamayacağını kastediyor; bu ihtirazî kayıt, kayıplığı sırasında mûrisinin ölmesi ve sonra sağ olduğunun ortaya çıkması durumunda mirasçı olabileceğini belirtmek içindir” şeklinde açıklanmıştır. Şeyhîzâde ayrıca, musannifin, "Ona düşen pay -tamamı veya bir kısmı olmak üzere- koruma altına alınır" ifadesiyle şayet tek mirasçı ise terekenin tamamının, başka mirasçlarla birlikte ise bir kısmının yediemine tevdi edilerek koruma altına alınacağını kastettiğini belirtmekte; ancak "gelirse" demek yerine "sağ olduğu ortaya çıkarsa" denmesinin daha iyi olacağına, zira gelmemiş olsa bile geçerli ispat vasıtalarılya sağ olduğu sübut bulursa hükmün aynı olduğuna dikkat çekmektedir. ${ }^{53}$

Diğer taraftan, özellikle Serahsî ve sonrası Hanefî fürû-i fikıh eserlerinde genellikle, mefkudun mirasçılığ 1 konusunda, "Mefkud kendi hakları konusunda sağ, başkalarının hakları konusunda ölü hükmündedir ("hayyün fî hakkı nefsihî ve meyyitün fî hakkı gayrihî”); şu halde onun malına mirasçı olunmaz ve o da başkasına mirasçı olamaz" şeklinde kalıp bir ifadenin tekrar edildiği görülmektedir.

Serahsînin (ö. 483/1090) el-Mebsût’ta bu meseleyi iki ayrı yerde ele alırken nispeten farklı bir sunum tercih ettiği belirtilmelidir. Şöyle ki: Çok önceki veya sonraki ciltlerde yer alan bahislere yaptığı iç atıflardan muhteşem

50 II, 217 .

51 II, 553 .

52 Oysa birçok Hanefî fürû eserinde, "Mefkud -kayıplığı sırasında vefat eden- hiç kimseye mirasçı olamaz" ibaresi “yani ölümüne hükmedilmeden önce” şeklinde açıklanmaktadır (mesela bk. Zeylaî, Tebyînül-hakāik, III, 312; İbn Nüceym, el-Bahrürr-râik, V, 178; İbn Nüceym, en-Nehrül-fâik, III, 292).

53 II, 553 . 
eserinin her bölümünde yazdıklarına ne kadar hâkim olduğu açıkça görülen müellif XI. ciltte mefkud ile ilgili genel bölümü teşkil eden "Kitâbü'l-Mefkūd"un başında mefkudun başkalarının hakkı hususunda "ölü hükmünde olduğu"nu, dolayısıyla ölen yakınına "mirasçı olamayacağı"nı ve -istishap delilinin işletilmesine ilişkin açıklamalarla destekleyerek- "başkasının mirası üzerinde hak sahibi olamayacağı”nı ifade etmesine mukabil, ilerleyen sayfalarda onun durumunun ceninin durumu ile benzerlik taşıdığını, yaşayıp yaşamadığı bilinmediğinden payının koruma altına alınacağını söyleyerek bu ifadelere açıklık getirmekte, ${ }^{54}$ eserinin son cildinde, mefkudun mirasçılığını özel olarak incelediği “Mîrâsü’l-mefkūd" başlığında, konuya başlarken "mefkudun sağ mı ölü mü olduğu hususunda tereddüt edilen bir kimse olması" itibariyle cenine benzediğini ve bu sebeple "Mîrâsü'l-haml" (ceninin mirasç1lı̆̆ı) başlığından sonra bu bahse geçtiğini belirtmekte, -kendi malı konusunda sağ, başkasının malı konusunda ölü sayıldığı kaidesini açıklarken- öldüğü bilinmedikçe malının mirasçıları arasında taksim edilmeyeceğini, yakınlarından biri vefat ettiğinde de durumu açıklığa kavuşmadan kendisine onun mirasının "verilmeyeceğì"ni ve ceninde olduğu gibi payının koruma altına alınacağını ifade etmekte, "Mirasçı olamaz" ("lâ yerisu") ibaresini kullanmamaktadır. ${ }^{55}$

"Mefkud kendi hakları konusunda sağ, başkalarının hakları konusunda ölü hükmündedir" şeklindeki anlatımı mezhep hükmünü yansıtma açısından sağlıklı bulmadığı anlaşılan Kâsânî (ö. 587/1191), Hanefî meşayihinden mezkûr ifadeyi naklettikten sonra, aynı kişinin gerçekte hem sağ hem ölü olmasının imkânsızlığına dikkat çekip bu ibare ile ne kastettiklerini açıklamakta; fakat iyi incelendiğinde şu sonuca varıldığını belirtmektedir: "Onun ne durumda olduğu bilinmemektedir, hayatta olması da ölmüş olması da muhtemeldir; (...) Eğer yakınlarından biri vefat ederse, -halihazırda hem sağ hem ölü olma ihtimali bulunduğundan- sağ mı ölü mü olduğu açıklığa kavuşuncaya kadar miras payı koruma altına alınır." ${ }^{56}$

Kâsânîye yakın bir coğrafyada yetişmiş ve onun çağdaşı olan Secâvendînnin (ö. 596/1200 [?]) miras hukukuyla ilgili eserinin Hanefî muhitindeki özelliği sebebiyle bu meselede yaptığı açıklamaya, -tekrardan kaçınmak üzere- makalenin sonuçlar ve değerlendirmeler içeren (8.) nolu başlığı altında değinilecektir.

54 XI, 34-35, 43-44, 45-46, 47, 48.

$55 \mathrm{XXX}, 54$.

56 Bedâi', VI, 196. 
Hanefî fikhının dört temel metninden sayılan Mevsılînin (ö. 683/1284)

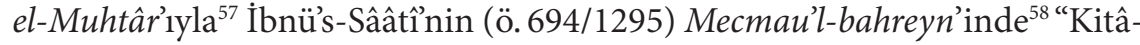
bü’l-Mefkūd" başlığı altında, "mefkudun kendi hakları/malı konusunda sağ, başkasının hakları/malı konusunda ölü hükmünde" olduğu ifade edilmiş olup, mefkudun -kayıplığı sırasında vefat eden- yakınına mirasçı olup olamayacağı meselesine değinilmemiştir. Dolayısıyla sadece bu metinleri okuyanlar, mefkudun payının koruma altına alınacağı hakkında bilgi edinememekte, aksine kendisine ölüler hakkındaki hükümlerin uygulanacağını öğrenmektedir.

Hanefî fürû-i fıkıh yazımında ve öğretiminde çok etkili olmuş ve üzerlerine onlarca şerh ve haşiye yazılmış olan Merginnânînin (ö. 593/1197) el-Hidâye'siyle ${ }^{59}$-dört temel metinden biri sayılan-Ebüll-Berekât en-Nesefînin (ö. 710/1310) Kenzü'd-dekāik'inde; ${ }^{60}$ Molla Hüsrev'in (ö. 885/1480) Osmanlı medreselerinde ders kitabı olarak okutulduğu gibi kadı ve müftülerin baş ucu kitabı olan Dürerü̉l-hükkâm fî şerhi gureri'l-ahkâm'ında; ${ }^{61}$ son dönemin en muteber Hanefî fikıh kaynaklarından olan İbn Âbidîn'in (ö. 1252/1836) Reddü'l-muhtâr adlı kıymetli Hâşsiye'sinin metnini oluşturan Timurtaşînin (ö. 1004/1596) Tenvîrü'l-ebsâr'ı ile Haskefînnin (ö. 1088/1677) ed-Dürrü’l-muhtâr adıyla buna yazdığı şerhte, ${ }^{62}$ önce "mefkudun başkasına mirasçı olamayacağı" ve/veya "mefkudun başkalarının hakları konusunda ölü hükmünde olduğu" ifade edilmekle birlikte, genellikle devamında mûrisinin ve vasiyetçisinin malından onun payının ayrılıp koruma altına alınacağının belirtilip, bu payın ne zamana kadar tutulacağı, sağ veya ölü olduğunun anlaşılması durumunda ne yapılacağı hakkında bilgi verilmesi, "Mefkud mirasçı olamaz"

57 el-Muhtâr, III, 37-38. Öte yandan Mevsılî anılan metne yazdığı el-İhtiyâr li-ta'lîli'lMuhtâr adlı eserinin, "Kitâbü'l-Mefkūd" başlığı altında, "Başkasının hakları konusunda ölü hükmündedir" ifadesini, "Kayıplığı sırasında ölene mirasçı olamaz, çünkü onun varlığının devamına hükmedilmesi istishâbü'l-hâle göredir; bu ise def 'ide (hüccet olmaya) elverişlidir ama hak elde etmede elverişli değildir" şeklinde açıklamıştır (III, 37). Bu konuya ilişkin başka açıklama yapmamakla birlikte mefkud hakkındaki kalan meselelerin "Ferâiz" bahsinde geleceğini belirtmiş; elİhtiyâr'ın beşinci cüzünde, mefkudun payının ayrılmasına ilişkin daha önce bir bilgi vermiş olmadığı halde, ölümüne hükmedilmesi durumunda kendi malları için ne yapılacağını yazdıktan sonra, "başkasının terekesinden mefkud için ayrılan paya gelince" deyip bunun o kişinin vârislerine iade edileceğini ifade etmiş; ardından da söz konusu payın mevcut mirasçılar tablosuna göre nasıl hesap edileceği hakkında kısa bilgi vermiştir ( $\mathrm{V}, 114-15)$.

58 s. 496.

$59 \mathrm{~V}, 374$.

60 III, 292-93.

61 II, $159-60$.

62 XIII, 247-54. 
şeklindeki önermenin zihinlerde yer etmesini bir ölçüde önleme açısından olumlu sayllabilir.

Yukarıdaki tespitler ışığında şu değerlendirmeleri yapmak mümkündür:

(1) Hanefî fikhının özünü sonraki nesillere intikal ettirmede önemli bir rol üstlenmiş ve İslam dünyasında asırlar boyunca haklı bir şöhret elde etmiş olan (hatta "el-Kitâb" ve "Kudûrî-yi Şerîf" diye de anılan) Kudûrînin el-Muhtasar'ının, mezhebin ana kaynağı el-Asldakini tam olarak yansitmayan bir bilgi vermesi sebebiyle, ele aldığımız konu açısından önemli bir kırılma noktası teşkil ettiği, buradaki ifade ile sonraki Hanefî fürû literatüründe, "mefkudun, kayıplığı sırasında vefat eden yakınına mirasçı olamayacağı" bilgisinin yaygın biçimde görülmesi arasında sıkı bir ilişkinin bulunduğu söylenebilir.

(2) Muhtasar yazmanın zorlukları dikkate alınarak Kudûrînin metni bu şekilde oluşturmasına ilişkin bazı yorumlar yapılabilirse de, özellikle bu esere yazılan şerhlerde beklenen açıklamanın bulunmaması ve fikıh öğretiminde (özellikle medreselerde, hatta yakın zamanlara kadar Ezher'de) öne çıan bir ders kitabı olması sebebiyle el-Muhtasar'daki, "Mefkud, kayıplığı sırasında vefat eden hiç kimseye mirasçı olamaz" bilgisinin -mefkud için pay ayrılacağına dair bir kayıt da taşımaksızın- öğrencilerin hafızalarına yerleştirilmesine devam edilmiştir.

(3) Mefkudun yakınlarından birinin vefat etmesi durumunda sağ veya ölü olduğu belli oluncaya kadar yakının terekesinden kendisine düssen payın koruma altına alınacağ başkalarının hakları konusunda ölü hükmündedir" ve "Mefkud, kayıpl1ğ 1 sırasında vefat eden hiç kimseye mirasçı olamaz" şeklindeki önermeler usul kitaplarındaki yanlış ezberi besleyen veya bundan etkilenerek yapılan açıklamalar olarak değerlendirilebilir. Zira başkalarından kendisine intikal edecek haklar konusunda, "Ölü hükmündedir" ve "Mirasçı olamaz" şeklinde kategorik önermeler mezhepteki fürû hükmünü ve gerekçesini sağlıklı biçimde yansıtmadığı gibi, zamanla yaygınlık kazanan, "Mefkudun -kayıplığ sırasında- bir yakını vefat ederse Hanefîler'e göre ona mirasçı olamaz, ama Şâfiîler'e göre mirasçı olur" şeklindeki sunumun Hanefîler ile Şâfiîler arasındaki istishap deliliyle ilgili ihtilafı açıklayan bir örnek haline getirilmesine de zemin hazırladığı anlaşılmaktadır. ${ }^{63}$ Esasen "Ölü hükmündedir" önerme-

63 Bardakoğlu şu açıklamasıyla bu hususa dikkat çekmektedir: "Ancak hukuk ekollerinin belirli fer'î meselelerde benimsediği çözüm örneklerinden hareketle istishap anlayışlarıyla ilgili genelleme yapmanın, mesela mefkud örneğinden yola çıkarak kategorik belirlemelere gitmenin yanıltıcı olacağını da göz ardı etmemek gerekir. Kaynaklarda 
sinin beklenen pratik sonucu mefkudun mirasçı olamayacağına, dolayısıyla ölen yakınına ait terekenin o yokmuş gibi mevcut vârislere taksim edilmesine hükmedilmesi iken, -mirasçı tablosuna göre hangisi mefkudun lehine ise ona göre hesap yapılarak- kendisine pay ayrılıp koruma altına alınmasını izah etmek kolay değildir. ${ }^{64}$

"Ölü hükmündedir” ve "Mirasçı olamaz" șeklindeki anlatımla, "Yakını vefat ettiğinde sağ olup olmadığı bilinmediği için ona doğrudan mirasçı muamelesi yapılmaz, yani mirastaki payı onun mülküymüş gibi fiilen ayrılıp ilgililere verilmez" anlamının kastedildiği tarzında açıklamalar yapılabilirse de, ${ }^{65}$ bu defa Şâfiîler için söylenen, "Mirasçı olur” önermesini izah zorlaşır; çünkü onlara göre "mefkuda doğrudan mirasçı muamelesi yapıldığı, yani mirastaki payının onun mülküymüş gibi fiilen ayrılıp ilgililere verildiği", ayrıca diğer vârislerin paylarının da onun vâris olduğu esasına göre hesap edileceği söylenmiş olur. Oysa ilgili başlıkta görüleceği üzere, bu konuda Şâfiî mezhebindeki hüküm Hanefî mezhebindekinden farklı değildir.

(4) Mefkudun kayıplığı döneminde vefat eden yakınına mirasçılı̆̆ susunda bir taraftan "ölü hükmünde sayılacağı ve mirasçı olamayacağı”, diğer taraftan "sağ veya ölü olduğu anlaşılıncaya kadar miras payının koruma altına alınacağı" bilgisinin karma biçimde verilmesinin Hanefî fıkıh kitaplarında gözlemlenen genel bir durum olması yanında, birçoğunda birinci önerme o kadar ön plana çıkarılmaktadır ki ikinci önerme (miras payının koruma altına alınacağı hükmü) belli belirsiz kalmakta ve okuyucu bunu ancak özel bir dikkat gösterirse farkedebilmektedir. Zira bazı eserlerde asıl konu olan mirasçılık durumu ve mefkudun miras payının ayrılması hükmü ileriye bırakılıp araya vasiyet örneği konmakta ve/veya özellikle Şeybânînin eserindeki ilk örnek olayın etkisi altında zilyetlik veya ispat sorunlarıyla ilintili örnekler üzerinden yürünerek asıl hüküm ikinci planda bırakılmaktadır. Mesela Hidâye şerhleri arasında seçkin bir yere sahip olan İbnü’l-Hümâm’nn (ö. 861/1457) geniş hacimli ve ilim muhitlerinin büyük

hukuk ekollerinin ve özellikle Hanefîler’in bu konudaki görüşleri aktarılırken çelişkili bilgilere rastlanmasının bir sebebi de bu olmalıdır" (“İstıshâb”, s. 379-80).

64 Ünalan mefkud ile ilgili makalesinde “... Çünkü kişi, gaiplik anında kendisi için sabit olmayan haklar açısından tam olarak ölü değil, ölü ile diri arasında muallak bir konumda kabul edilmiştir. O halde kuralı 'Gaip kendisine ait haklar açısından sağ, başkasına ait haklar açısından ise ne sağ ne de ölüdür' şeklinde düzeltmek daha doğrudur” diyerek yaygın anlatımı eleştirmektedir (bk. "İslam Hukukunda Gaibin/Mefkûdun Evlilik ve Miras Durumu", s. 119).

65 Mesela Kurlânî (ö. 767/1366), bu anlatımın yanlış anlaşılmaya müsait olduğunu farkederek şöyle bir açılama yapma ihtiyacı duymuştur: "Mefkud başkasına mirasçı olamaz' sözümüz, 'Mefkudun mirastaki payı mefkudun mülkü olmaz; mefkudun miras payı koruma altına alınır' anlamındadır” (bk. el-Kifâye, V, 374). 
takdirine mazhar olmuş Fethu'l-kadîr isimli eserinde, mefkudun kaybolduğu dönemde mûrislerinden biri vefat ederse -istishabın "istihkak"a elverişli delil olmaması sebebiyle- ona mirasçı olamayacağı ifade edilmekte, devamındaki açıklamalarda, Şeybânînin el-Asl’ında yer alan ilk örnek olay esas alınarak terekeye dahil mallar üzerindeki zilyetlikle veya (mefkudluk iddiasının taraflarca kabul edilip edilmemesine ilişkin) ispat sorunlarıyla ilgili meselelere kayıldığg görülmektedir. ${ }^{66}$ Haskefînin ed-Dürrül-muhtâr'ına bakıldığında da bu durumla karşılaşılmakta ve İbn Âbidîn'in yaptığı açıklamalar sayesinde, -kayıplığı sırasında- bir yakını vefat eden mefkud için -hacb kurallarına göre- kendisinin lehine olan payın ayrılacağ kolay anlaşılmaktadır. Yine Mecelle şârihi Ali Haydar Efendi (1853-1935), konuya ilişkin özel çalışmasının (Risâle-i Mefkūd) başında mefkudun başkalarının hakları bakımından ölü sayıldığını belirtmekte ve "Binaenaleyh mefkud hâl-i fakdında vefat eden mûrisine vâris olamaz" ${ }^{67}$ deyip bu konunun ayrıntısı için "35 numaralı mesele” ye atıfta bulunmaktadır. Her ne kadar anlatımın sonunda mefkudun miras payının ayırılıp kayyım tarafından muhafaza altına alınacağı söylense de, risalede iki defa geçen, "Mirasçı olamaz/Mirasçı olmaz” önermesinden, ilk bakışta ona pay ayrılmayıp mevcut mirasçılara göre miras taksiminin yapılacağının anlaşılabileceği göz ardı edilmemelidir. ${ }^{68}$

(5) Başka birçok konuda Şâfiî̀nin veya Şâfiîler'in görüşleriyle mukayeseler yapan Hanefî fürû müelliflerinin, Hanefîler'in, "İstishâbü'l-hâl hak kazanımı için hüccet teşkil etmez" şeklindeki yaklaşımını mefkudun mirasçı olamaması örneği ile açıkladıkları bir bağlamda karşı görüşe (Şâfî̀ler’e göre yakını ölen mefkudun mirasçı olduğuna) değinmemeleri dikkat çekmektedir. ${ }^{69}$ Bunun, belirtilen meselede Şâfiî kaynaklarında farklı görüşe yer verilmemesinden kaynaklandığı açıktır. Nitekim özellikle bu iki mezhep arasındaki fikhî ihtilafları ele alan eserlerde de böyle bir görüş ayrılığından söz edildiğine rastlanmamaktadır. ${ }^{70}$ Şayet Hanefî fürû eserlerin-

$66 \mathrm{~V}, 375$

67 s. 5 .

68 Hanefî fürû literatüründeki bu genel durumun alanın uzmanlarını bile etkilediğinin ilginç bir örneği (Mustafa Dîb el-Bugānın Eserü'l-edilletill-muhtelef fîhâ adlı doktora tezi) (7.) nolu başlık altında incelenecektir.

69 Ali Haydar mezkûr risalenin "Hâtime"sinde, "Mefkud hakkında diğer eimme hazerâtının mezhepleri beyanındadır" deyip yeni bir mesele başlı̆ğ koymuş olmakla birlikte, açıklamalarını mefkudun mal varlığı ve zevcesi ile ilgili hükümlerle sınırlı tutmakta; özellikle fikıh usulü eserlerinde istishap delilinin işletilişinde meşhur olan Hanefîler'le Şâfiîler arasında mefkudun mirasçılı̆̆ 1 meselesindeki ihtilafa değinmemektedir (Risâle-i Mefkūd, s. 24-25).

7o Kudûrînin Hanefîler ile Şâfiîler arasındaki ihtilaflı meseleleri delilleriyle birlikte 
de Şâfiîler'de de yakını ölen mefkudun fiilen mirasçı sayılmayıp -durumu açıklığa kavuşuncaya kadar- payının ayrılması hükmünün geçerli olduğu belirtilmiș olsaydı, usul kitaplarındaki yanlıs ezber sürüp gitmeyebilirdi; zira Hanefî fıkhını öğrenme konumunda olanların sırf bu mesele için Şâfî̀ fıkıh kaynaklarına başvurmaları mûtat öğrenim süreçleri muvacehesinde fazla beklenmez.

Ancak belirtmeliyiz ki mukayeseli incelemelerin fürû eksenli olması durumunda belirtilen faydanın sağlanabileceği, fıkıh usulü esas alındığında ise durumun değişmeyeceği anlaşılmaktadır. Nitekim Rükneddin es-Semerkandînnin (ö. 701/1301) Câmiu'l-usûl fî beyâni'l-kavâidil-Hanefiyye veş̧-Şâfiiyye fî usûli'l-fikh adlı eserinde, istishap konusunda Şâfiîler ile Hanefîler arasındaki usul ihtilafına değinilmesini ${ }^{71}$ takiben değişik örnekler üzerinde durulmakla birlikte mefkud örneği hakkında, “... Bu sebeple biz, mefkudun kendi malı hakkında sağ, başkasının malı hakkında ölü sayılacağı, dolayısıyla sırf zâhiren hayatta olmasına binaen ölen yakınına mirasçı olamayacağı üzerinde icmâ etmiş bulunuyoruz" ${ }^{72}$ denmekte, yani mukayese usul eserlerinin etkisi altında kalınarak yapıldığı için Hanefîler'e göre mefkudun mirasçı olamayacağı bilgisi yanında -dolaylı da olsa- Şâfiîlere göre mirasçı olacağı bilgisi verilmiş olmaktadır.

Sonuç olarak, Hanefî fürû eserlerinde, yakını ölen mefkudun mirasçı olup olamayacağı meselesi ele alınırken, bunun sağ veya ölü olduğu açılılık kazandığında belli olacağı ve bu sebeple yaşadığı ihtimaline binaen miras payının ayrılacağı bilgisiyle yetinilmesi yerine, henüz askıda sayılan bir durum için ("Ölü hükmündedir" ve "Mirasçı olamaz" şeklinde) kesin sonuç bildiren kural ve anlatımların öne çıkarılmasıyla usul öğretiminde mefkudun mirasçıllğı meselesindeki (gerçekte var olmayan) ihtilafın istishap delilinin uygulanışının simgesel bir örneği hale gelmesi arasında sıkı bir ilişki olduğu, hatta Hanefî fürû eserlerindeki yanlış veya eksik ezberin, fikıh usulü öğretiminde, "Mefkud Şâfiîler’e göre mirasçı olur" şeklindeki yanlışlı̆̆ kesin olan (ama farkına varılamayan) bir ezberden de destek alınarak pekiştirildiği söylenebilir.

incelediği geniş hacimli kitabı et-Tecrîd'de belirtilen görüş ayrılı̆̆ından söz edilmemesi önemlidir; zira -yukarıda belirtildiği üzere- Hanefî fürû eserlerinde bu meselede büyük ölçüde onun el-Muhtasar’ı esas alınmıştır (et-Tecrîd'de "Mefkud" başlığını taşıyan bir bölüme ve "Talâk", "Ferâiz", "Vesâyâ" bölümlerinde mefkudun mirasçılığ ne rastlayamadik).

71 II, 180 .

72 II, 186. 


\section{4. Şâfiî Fıkıh Usulü Eserlerinde Mefkudun Mirasçılığı Meselesi}

İncelediğimiz Şâfiî fikıh usulü eserlerinde ${ }^{73}$ istishabın hüccet değeri üzerinde durulurken, Şâfiîler'e/Şâfiî̀ye göre istishâbü'l-hâl yeni haklar kazanılmasında geçerli bir delil sayıldığ için, kayıplığı sırasında yakınlarından biri vefat ederse mefkudun ona mirasçı olacağı bilgisine rastlanmamaktadır. ${ }^{74}$

Şâfiî usul eserleri içinde Ezher şeyhi Abdurrahman b. Muhammed eş-Şirbînî (ö. 1908) tarafından yapılan açıklamalar, araştırma konumuz açısından özel bir önemi haizdir. Şöyle ki: Tâceddin es-Sübkî (ö. 771/1370) Cem'u'l-cevâmi` isimli eserinde istishaptan söz ederken mefkudun mirasçıllğı örneğini zikretmemekte, ${ }^{75}$ Celâl el-Mahallî (ö. 864/1459) onun istishap ile ilgili ifadelerini şerhederken -asıl konuyu Şâfiî mezhebine istishap hakkında nispet edilen usulî görüşle ilgili açıklama ve tartışmalar oluşturmakla birlikte- mefkudun mirasçılığına değinerek ölümüne hükmedilmeden önceki dönemde onun hayatta olduğuna dair bilginin def'ide hüccet olsa da ispatta hüccet sayılmayacağını, dolayısıyla istishaba binaen başkasına mirasçı olup yeni bir mülkiyet kazanamayacağını belirtmekte, ${ }^{76}$ Bennânî (ö. 1198/1784) ve Attâr da (ö. 1250/1834) Hâşiye'lerinde bu konudaki ifadeleri açılamaktadır. ${ }^{77}$ Ezher şeyhi Şirbînî ise Takrîr' inde, et-Tavzîh sahibinin (Sadrüşşerîa), mefkud örneğini kullanırken, "Şâfiî̀ye göre mirasçı olur, ama bize göre olmaz" şeklinde aktardığı bilginin, dolayısıyla mefkudun mirasçıllğı meselesinin Şâfiîler ile Hanefîler arasında ihtilaflı gösterilmesinin yanlış olduğuna dikkat çekmekte; bu arada mefkudun mirasçıllğı hakkında Remlî ve İbn Hacer'in Gazzâlîden naklettiği ifadeye yer verip, bununla ne kastedildiğine ve şârihin ifadelerine açıklık getirmeye çalışmaktadır. ${ }^{78}$ Dolayısıyla bazı yazarlarca Şâfiî mezhebinde mefkudun kayıplığı sırasında ölen yakınına mirasçı kılındığı bilgisi için,

73 Mesela Şîrâzî, Şerhu'l-Lüma', II, 977-93; a.mlf., et-Tebsıra, s. 526-37; Cüveynî, el-Burhân, II, 1135-41; Gazzâlî, el-Mustasfâ, I, 217-45; İbn Berhân, el-Vüsûl, II, 317-19 (Müellif burada hükmün devamının istishap yoluyla olduğu tezini savunan Debûsîden söz ederken mefkud örneğine -onun usulî yaklaşımını eleştirmek üzere- değinmektedir); Âmidî, el-İhkâm, IV, 111-20; Fahreddin er-Râzî, el-Mahsûl, II, 475-84.

74 Haral Yalçı da, İlk Beş Asır Usulül-Fıkh Literatüründe İstıshab Delili başlıklı doktora tezinde, araştırmasına kaynaklık eden Şâfiî usul eserlerinde Şâfiîler'in mefkudun durumunu istishapla bağlantılı olarak değerlendirdiklerini ortaya koyan herhangi bir ifadeye rastlamadığını belirttikten sonra, "Bununla birlikte onların usulde mefkudu hangi bağlamda değerlendirdiklerini, Hanefî usul eserlerinde, yine Hanefỉler tarafından onlara izafe edilen görüşlerden öğrenmekteyiz" (s. 156, 195-96) açıklamasını yapmıştır.

75 Sübkî, Cem'u'l-cevâmi', II, 386-89.

76 Mahallî, Şerhu'l-Celâl el-Mahallî, II, 386-89.

77 Bennânî, Hâş̧iye, II, 349 (Burada mefkudun payının ayrılacağından da söz edilmektedir); Attâr, Hâşiye, II, 386-89.

78 II, 386-87. 
aksi yönde bir bilgi içerdiği halde Şerhu'l-Mahallî alâ Cem'i'l-cevâmi' isimli eserin kaynak gösterilmesi yanıltıcı olmaktadır. ${ }^{79}$

Yine Tâceddin es-Sübkînnin (ö. 771/1370) -babası Takıyyüddin es-Sübkî (ö. 756/1355) tarafından telifine başlanmış olan- el-İbhâc fî̀ şerhil-Minhâc adlı eserinde, Hanefîler tarafından mefkudun istishâbü'l-hâl ile yaşadığına hükmedilmesinin kendi mülkünün devamında hüccet olmaya elverişli sayıldığı, ama mûrisinin malında onun lehine mülkiyet ispatına elverişli sayılmadığı belirtilmekte, Şâfiîler'e göre mefkudun mirasçı olacağından söz edilmemekte, hatta mefkudla ilgili başka bir bilgiye yer verilmemektedir. Buna rağmen bazı yazarlarca Şâfiî mezhebinde mefkudun kayıplığ1 sırasında ölen yakınına mirasçı kılındığı bilgisi için, mezkûr eserin kaynak gösterilmesi okuyucuyu yanıltmaktadır. ${ }^{80}$

İsnevî̀nin (ö. 772/1370), Nihâyetü̉s-sûl fî şerhi Minhâci'l-usûl li'l-Beyzâvî adlı eserine Misır Başmüftüsü Muhammed Bahît el-Mutî̂nin (1854-1935), Süllemüll-vüsûl li-şerhi Nihâyetis-sûl adıyla yazdığı haşiye de araştırma konumuzla ilgili açıklamalar içermektedir. Şöyle ki: İsnevî "Makbul Delillerin İkincisi İstishâbü'l-hâl" başlığı altında bu delil ile ilgili görüşlere değinmekle birlikte "mefkud"dan hiç söz etmemekte; ${ }^{81}$ buna karşllık Mutîi anılan haşiyede mefkud ile ilgili geniş açıklamalara yer vermektedir. Bunlardan araştırmamız açısından özel önemi haiz olanı, Sadrüşşerîảnın ve Fevâtihu'r-rahamût sahibinin (Bahrülulûm el-Leknevî), "Mefkud, Şâfiîye göre -kaybolduktan sonra vefat eden- yakınına mirasçı olur, bize göre ise mirasçı olamaz" şeklinde verdikleri bilginin ve bunu iki mezhep arasındaki ihtilaf çerçevesine dahil edilmesinin yanlış olduğuna dikkat çekmesidir. Ancak bu bağlamda yazdıkları, hocası Ezher Şeyhi Şirbînînin açıklamalarının tekrarı mahiyetinde olup kendisi de bu konudaki sözü uzatma sebebinin, ancak hocası Şirbînî gibilerin farkedebildiği incelikler taşıması olduğunu ifade etmektedir. ${ }^{82}$ Sekkā Şâfiîler'in de içinde bulunduğu cumhurun mefkudun mirasçı olacağ 1 görüşünde olduğu bilgisi için Şerhu'l-İsnevî̀ yi de kaynak gösterirken, ${ }^{83}$ Mutî̂̀nin

79 Mesela (6.1.) ve (7.) nolu başlıklarda görüleceği üzere Vehbe ez-Zühaylî gerek fıkıh usulü gerekse fürû ile ilgili kitabında bu konuya ilişkin yanlış bilgiyi aktarırken anılan eseri kaynak göstermiştir.

8o Mesela (6.1.) ve (7.) nolu başlıklarda görüleceği üzere Vehbe ez-Zühaylî gerek fikıh usulü gerekse fürû ile ilgili kitabında ve Sekkā doktora tezinde inceleme konumuz olan yanlış bilgiyi aktarırken anılan eseri kaynak göstermişlerdir.

81 IV, 358-60, 366-73.

82 IV, 360-66, 369-70.

83 Ahkâmü'l-gāib ve'l-mefkūd, s. 686. Burada yazar belirtilen bilgi için Zerkeşînin (ö. 794/1392) el-Bahrül-muhît' ini de kaynak göstermektedir; oysa Zerkeşînnin bu bağlamda sadece mefkudun ölen yakınına mirasçı olamayacağına dair Hanefî görüşünden söz 
mezkûr haşiyede mefkud ile ilgili olarak yaptığı açıklamaların İsnevîye ait olduğunu düşünmüş olmalıdır. Fakat böyle bile olsa, bu haşiyede Sekkänın iddia ettiği yönde bilgi verilmemekte, aksine Şâfiî̀ye bu yönde nispet edilen bilginin doğru olmadığı açıklanmaktadır.

\section{5. Şâfiî Fürû-i Fıkıh Eserlerinde Mefkudun Mirasçılığı Meselesi}

İncelediğimiz Şafiî fürû-i fikıh eserlerinde, Şâfiîler'e/Şâfiî̀ye göre istishâbü'l-hâl yeni haklar kazanılmasında geçerli bir delil sayıldığı için, kayıplığı sırasında yakınlarından biri vefat ederse mefkudun ona mirasçı olacağı bilgisine rastlanmamaktadır. Tam aksine bu konuda Hanefîler'de olduğu gibi, mefkudun sağ mı ölü mü olduğu bilinmediğinden, durumu açıklığa kavuşuncaya kadar payının ayrılacağı belirtilmekte, sağ dönmesi ihtimali dikkate alınarak, ihtiyaten (mevcut mirasçı tablosuna göre alabileceği) en yüksek payın ayrilıp koruma altına alınması esası benimsenmektedir.

Görebildiğimiz Şâfiî fürû eserleri içinde ${ }^{84}$ ilk olarak Mehâmilînin (ö. 415/1024) el-Lübâb fill-fikhiş-Şâfî̀ssinde, "Mefkud mirasçı olamaz; öldügünden emin olununcaya kadar payı koruma altına alınır" denerek bu meselenin hükmüne kısaca yer verildiği görülmektedir. ${ }^{85} \mathrm{Bu}$ ifade, araştırma konumuzla ilgili olarak şu ilginç tezatı gösterme açısından önemlidir: Erken dönem bir Şâfiî fürû eserinde, "Mefkud mirasçı olamaz" tarzında açık bir ifade kullanılmasına mukabil, Hanefî ilim muhitinde, "Şâfiîye göre mefkud mirasçı olur” önermesi yaygınlık kazanabilmiştir.

"Şâfiîler'e göre mefkudun -kayıplığı sırasında vefat eden- yakınına mirasçı olduğu" şeklindeki iddianın gerçeği yansıtıp yansıtmadığının ortaya konması, çalışmamızda merkezî bir öneme sahip olduğu için, bu konuda Şâfiî fürû eserlerindeki bilgilerin özünü çıkarıp ilgili kaynaklara atıfta bulunmakla

ettiği, cumhura/Şâfiîler'e mirasçı olacağı görüşünü nispet etmediği, hatta Kiyầdan bu örnekle ilgili yaptığ nakilde, onun -gerekçelendirmedeki anlatım farklılığı bir yana- bu hususta ihtilafın olamayacağına dair ifadesine yer verdiği görülmektedir (bk. VI, 17-20).

84 Şâfiînnin (ö. 204/820) el-Ümm'ünde mefkudla ilgili bazı meselelere değinilmekle birlikte (mesela bk. IV, 74-75, V, 239-41), ilgili bölümlerde onun mirasçılığı meselesinin ele alındığına rastlanmamaktadır; ancak fıkıh literatüründe genellikle mefkudun vasiyet lehtarı oluşuyla önemli benzerlik taşıdığına dikkat çekilen cenin lehine vasiyet meselesine yer verildiği ve vasiyet edilen malın ceninin doğumuna kadar koruma altına alınacağı belirtilmektedir (IV, 112). Yine Büveytînnin (ö. 231/846) el-Muhtasar'ı ile Müzenînin (ö. 264/878) el-Muhtasar'inda ve İbnü'l-Kās'in (ö. 335/946) et-Telhîs'inde bu meseleye özel olarak değinildiği görülmemektedir. Ancak Müzenînin "Mirasçı Olamayacak Kimseler” babında yer verdiği “ölümü karanlıkta kalanlar” ifadesi (s. 186), -aşağıda görüleceği üzere- Mâverdî tarafından "suda boğulanlar" ve "mefkudlar" şeklinde açıklanmıştır.

85 s. 279. 
yetinmek yerine, Mâverdînin (ö. 450/1058) el-Hâvî el-kebîr'inden itibaren son dönem eserlerine kadar uzanan çizgide meselenin ayrıntılı biçimde ele alındığı temel Şâfiî fürû eserlerindeki ifadelerden örnekler vermenin daha yararlı olacağını düşünüyoruz. Ayrıca bazı yazarların Şâfiî mezhebinde terekenin, "mefkud sağmış gibi düşünülerek taksim edileceği" ve "mefkud ölüymüş gibi düşünülerek diğer mirasçılara paylaştırılacağı" şeklinde iki görüş daha bulunduğu bilgisini vermelerinin nereden kaynaklandığına açıklık getirmek için de bazı ibarelerden nakillerde bulunmaya ihtiyaç duyulmuştur.

Mâverdî (ö. 450/1058) (Muhtasarül-Müzenî̀nin şerhi olan) el-Hâvî el-kebîr' inde "Mesele" başlığı altında, "Şâfiî (rahimehullah) şöyle demiştir: Ölümü karanlıkta kalanlar, suda boğulanlar ve mefkudlar olmak üzere iki sınıftı" "86 ifadesini kullanmakta, ${ }^{87}$ birinci sınıfla ilgili bilgileri takiben araştırma konumuz olan meseleye şu şekilde açılklk getirmektedir: "Mefkudun mirasçı olabileceği bir kimse ölürse, onun terekesinden mefkudun mirası -durumu açıklığa kavuşuncaya kadar- koruma altına alınır; şayet sağ olduğu anlaşılırsa ona mirasçı olur, eğer daha önce öldüğü anlaşılırsa vârislerden kalanlara iade edilir, ölümle ilgili durumu belirsiz kaldığ 1 takdirde de hüküm böyledir." ${ }^{\prime 8}$ Müellif daha sonra değişik mirasçı tablolarına göre mefkud için ayrılacak payla ilgili bilgi vermekte ve mefkudun hakkının söz konusu olmadığ durumlarda diğer mirasçıların kendi aralarında sulh olabileceklerini belirtmektedir. $^{89}$

Özü itibariyle aynı olan bilgi Şîâ̂zînin (ö. 476/1083) el-Mühezzeb fî fikhil-İmâm eş-Şâfî̀sinde şöyle ifade edilmiştir: "Bir adam esir alınır veya kaybolur da öldügü bilinmezse, emsalinin yaşayamayacağ 1 süre geçinceye kadar malı taksim edilmez; kendisine mirasçı olabileceği bir kimse ölürse, her mirasçıya kendisine isabet edebilecek en az pay verilir, kalanı onun durumu aydınlığa kavuşuncaya kadar koruma altına alınır."90 Şîrâzînnin oldukça muhtasar olan et-Tenbîh fî fürûi'l-fikhiş̧-Şâfî̀ adlı eserinde ise bu meseleye değinilmeksizin -başka birçok fikıh kitabında bu açıdan mefkud ile ortak

\section{VIII, 87.}

87 Şâfîinnin, hangisinin önce öldüğü bilinemeyenlerin mirasçılığı konusuna değinirken boğulanlar, toplu ölüme maruz kalanlar vb. "ölümü gizli kalanlar"ın -miras ehlinden olsalar da- birbirine mirasçı olamadıkları gibi mefkud ve zevcesinin de birlikte ölüp hangisinin önce öldüğü bilinemezse birbirlerine mirasçı olamayacaklarını söylediği (el-Üm, V, 240-41) dikkate alınırsa mefkudları "ölümü gizli kalanlar" ifadesinin kapsamında mütalaa etmediği ancak aynı hükme tâbi olduklarını belirtmek istediği anlaşılmaktadir.

88 VIII, 89.

89 VIII, 89-90.

$90 \mathrm{IV}, 83$. 
hükümlerine temas edilen- hünsâ-yı müşkilden söz edilmekte ve payının ayrrlacağ 1 belirtilmektedir. ${ }^{91}$

Kendisinden sonraki dönemde mezhep çevrelerinin telif faaliyetinde merkezî yere sahip olan ve tahkik döneminin "şeyhayn" diye anılan iki siması Râfiî ve Nevevî tarafından temel refans kabul edilen Gazzâlînnin (ö. 505/1111) el-Vecîz adlı eserinde, ${ }^{92}$ mefkudun bir yakının vefat etmesi durumunda payının ayrılacağ payın nasıl ayrılacağı şöyle açıklanmaktadır: "Mefkudun ölü olması durumunda payı eksilecek olan hakkında onun ölü olduğunu takdir ederiz, mefkudun sağ olması durumunda payı eksilecek olan hakkında onun hayatta olduğunu takdir ederiz. Fakat bir kavil şöyledir: Hepsi hakkında onun ölü olduğu takdir edilir; başka bir kavil ise şöyledir: Hepsi hakkında onun hayatta olduğu takdir edilir; sonra aksi durum ortaya çıkarsa hükmü değiştiririz." ${ }^{93}$

Râfiî (ö. 623/1226), Gazzâlî̉nin bu eserine yazdığı şerhte (el-Azîz fî şerhìl-Vecîz/eş-Şerhu'l-kebîr; Fethu'l-Azîz fî şerhi'l-Vecîz), "Şayet mefkudun ölümüne hükmedilmeden önce bir yakını vefat ederse, bakılır:" deyip yukarıda değinilen (el-Vecîz metnindeki) bilgileri yakın biçimde tekrar etmekte; ancak başta, "Mefkud ile birlikte bulunduğunda mirasçılığ 1 düşene, -mefkudun durumu açıklığa kavuşuncaya kadar- bir şey verilmez" ihtimaline, sonda da, "Mefkudun sağ veya ölü olması durumunda payı değişmeyene payı verilir" ihtimaline yer vermekte, ${ }^{94}$ devamında bu ihtimalleri farklı mirasçı tablosu örnekleriyle açıklamaktadır. ${ }^{95}$

Mezhep içindeki belirleyici konumu sebebiyle "şeyhayn" tabiriyle anılan iki fakihten biri olduğu gibi günümüz Şâfiîliği açısından da bir dönüm noktası teşkil eden Nevevînin (ö. 676/1277) yukarıda zikredilen eserin muhtasarı niteliğinde olup Şâfiî mezhebinin en güvenilir bilgi kaynaklarından kabul edilen ${ }^{96}$ (ve bu konudaki yayınlarda da en fazla başvurulan kaynaklardan biri olan) Ravzatü't-tâlibîn adlı eserindeki bilgilerin göz önünde bulundurulması da araştırma konumuz açısından önemlidir. Nevevî mefkudun mirasçılığ hakkında şöyle demektedir: "Ölümüne hükmedilmeden önce bir yakını vefat ederse bakılır: a) Mefkuddan başka vârisi yoksa, yakınının vefatı sırasında sağ mı ölü mü olduğu açıklığa kavuşuncaya kadar bekletiriz

\section{1 s. 398.}

92 Aybakan, "el-Vecîz", s. 587-88.

93 s. 250.

94 XI, 226.

95 XI, 227-29. Müellifin konumuz açısından önemli bazı tespitlerine (8.) nolu başlık altında değinilecektir.

96 Aybakan, "Şâfiî̀ Mezhebi”, s. 233-47. 
(terekenin tamamını koruma altına alırız), b) Mefkuddan başka vârisi varsa, mefkudun payını koruma altına alırız ve mevcut vârislerden her birinin payı konusunda en kötü olan seçeneği esas alırız, şöyle ki: aa) Mefkudla birlikte olduğu zaman sâkıt olacak olana onun durumu açıklığa kavuşana kadar bir şey verilmez, bb) Mefkudun sağ olması durumunda payı eksilecek olan bakımından mefkud sağ kabul edilir (payı buna göre hesap edilir), cc) Mefkudun ölü olması durumunda payı eksilecek olan bakımından mefkud ölü kabul edilir (payı buna göre hesap edilir), dd) Mefkudun sağ veya ölü olması durumlarında payında değişme olmayana ise payı verilir."97 Daha sonra Nevevî bu durumlara, mevcut vârislerlerle ilgili farklı ihtimaller üzerinden örnekler veriyor ${ }^{98}$ ve devamında şöyle diyor: "(Mirasçı tablolarına göre) her bir şekil hakkında zikrettiklerimiz 'sahih' ve 'zâhirü’l-mezheb' olandır. Fakat bir 'vecih'e göre, hepsi bakımından mefkudun ölü olduğu kabul edilir; zira mevcut vârislerin hak edişleri bilinmektedir, mefkudun hak edişi ise şüphelidir; şayet aksi ortaya çıkarsa hükmü değiştiririz. Başka bir 'vecih'e göre ise hepsi bakımından mefkudun sağ olduğu kabul edilir; zira asıl olan onun hayatta olmasıdır; şayet aksi ortaya çıkarsa hükmü değiştiririz."99

Nevevînnin Minhâcüt-tâlibîn adlı eserinin üç ünlü şerhi ${ }^{100}$ ile Nevevînin Menhecü't-tullâb’inın Zekeriyyâ el-Ensârî (ö. 926/1520) tarafından yapılan Fethu'l-vehhâb isimli şerhinde ve Büceyrimînin (ö. 1221/1806) bunun üzerine yazdığ $H_{a ̂ s} s i y e{ }^{\prime} e^{101}$ de yukarıdaki bilgilerin tekrar edildiği görülmektedir.

Dikkatli biçimde okunmazsa, Gazzâlînin, "Fakat bir kavil şöyledir: (...); başka bir kavil ise şöyledir: (...)" ve Nevevînnin Ravzatü't-tâlibîn'deki, "Fakat bir vecih şöyledir: (...); bu hususta başka bir vecih de şöyledir: (...)" şeklindeki ifadelerinden, bu görüşlerin ana hükmün (mefkudun payının koruma altına alınacağı hükmünün) dışında olduğu yani mefkudun mutlak olarak ölü veya sağ olduğu esas alınarak taksim yapılacağı anlamı çıkarılabilmektedir. Nitekim Ali Seyyid Hasan’ın ${ }^{102}$ "Tereke mefkudun sadece sağ olduğu farzedilerek taksim edilir" ve "Tereke mevcut mirasçılar arasında taksim edilir; zira o andaki mirasçıların yaşadığ kesindir, mefkudun yaşadığ şüpheli olduğuna göre o vâris olamaz" şeklinde iki görüş daha bulunduğunu söylerken bu ifadeleri esas aldığı anlaşılmaktadır. Oysa bu ifadeler dikkatle

$97 \mathrm{VI}, 35$.

$98 \mathrm{VI}, 35-36$.

$99 \mathrm{VI}, 36$.

100 Bk. İbn Hacer el-Heytemî, Tuhfetü'l-muhtâc, VI, 764-65; Şirbînî, Muğni'l-muhtâc, III,

33; Remlî, Nihâyetü'l-muhtâc, VI, 30.

101 III, 294-95.

102 el-Ahkâmü'l-hâssa, s. 65. 
okunduğunda, bunların mefkuddan başka vârislerin bulunması durumunda onun payı ayrılırken diğer vârislerin paylarının nasıl hesaplanacağına ilişkin olduğu sonucuna varılmaktadır.

$\mathrm{Bu}$ arada belirtilmelidir ki, bazı yazarlar mefkudun mirasçılığı meselesinde Hanefîler ile Şâfiîler arasında ihtilaf bulunduğu bilgisi için er-Rahbiyye'ye atıfta bulunmuş olsalar da, bu eserde bu yönde bir bilgiye rastlanmamakta, Şâfiî fikıh eserlerindeki mûtat bilgilerin tekrar edildiği görülmektedir. ${ }^{103}$

\section{Yakın Dönem Fıkıh Usulü Ders Kitaplarında Mefkudun Mirasçılığı Meselesi}

Önceki başlıklarda görüldüğü üzere, makale konusunu oluşturan ve fikıh usulü öğretiminde köklü bir geçmişe sahip olan yanlış ezber, on yıllardır İslam ülkelerinde (özellikle yükseköğretim düzeyinde) okutulan yakın dönem fikıh usulü kitapları vasıtasıyla zihinlere nakşedilmeye devam edildiği ve bu kitaplar hâlâ ciddi bir itirazla karşılaşmaksızın yayımlanmakta olduğu için, bu başlık altında bazı örnekler üzerinde durulacaktır.

XX. yüzyılın ikinci çeyreğinden itbaren günümüze kadar kaleme alınan bu örnekleri üç grup halinde inceleyeceğiz. ${ }^{104}$

\subsection{Fıkıh Usulü Öğretimindeki Yanlış Ezberin Açıkça Tekrarına Örnekler}

(1) Muhammed Ebû Zehre Usûlü'l-fikh adlı kitabında "el-istishâbü’l-hâs bi'l-vasf” tabir ettiği istishap türünün ne ölçüde delil teşkil edeceğinin fakihler arasında ihtilaf konusu olduğunu, Şâfiî ve Hanbelîler'in bunu mutlak bir hüccet olarak kabul ederken, Hanefî̀ ve Mâlikîler'in def'ide geçerli hüccet saymakla beraber ispatta geçerli saymadıklarını belirttikten sonra mefkud ile ilgili olarak şu açıklamayı yapmaktadır: "Hanefîler’e ve Mâlikîler'e göre mefkud kayıplık döneminde yeni haklar kazanmaz, dolayısıyla bu dönemde ona bir miras veya vasiyet malı kalmaz; mirasçlları arasında bulunduğu bir yakını bu dönemde vefat ederse mefkudun payı koruma altına alınır." 105 "Şầfiîler’e ve Hanbelîler’e gelince, onlar kayıplık döneminde -ölümüne karar verilmedikçe- mefkudun sağ olduğuna hükmederler; buna göre (...) mefkuda

103 Bk. Rahbî, er-Rahbiyye, s. 297-99; Birmâvî, Hâşiye, s. 267-69.

104 Muhammed el-Hudarînin, kendi beyanına göre 1905 yılında bir fakültede üstlendiği usûlü'l-fikh dersi dolayısıyla nüvesini oluşturduğu (s. 12-13) Usûlü'l-fikh'inda, istishap hakkında özlü bilgi verilip kısa bir değerlendirme yapılmakta; Hanefîler ve Şâfîller arasındaki usul ihtilafına ve mefkud meselesine değinilmemektedir (bk. s. 355-56).

105 S. 279. 
kayıplık döneminde miras veya vasiyet yoluyla sabit olan her türlü mal intikal eder."106

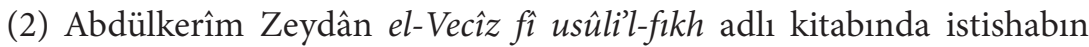
Hanefîler'e ve onlar gibi düşünenlere göre sadece def'ide hüccet olup ispatta hüccet olmadığını, -Hanbelîler ve Şâfiîler gibi- onların dışındakilere göre ise hem def'ide hem ispatta hüccet sayıldığını ve bu usul ihtilafının fürû-i fikha yansıyan örneklerinden birinin "mefkud" konusundaki görüş ayrılığ 1 olduğunu belirttikten sonra, şu açıklamaları yapmaktadır: "Hanefîler’e göre mefkud kendinden önce ölen yakınına vâris olamaz, yani mefkudun kayyı$\mathrm{m}$ onun miras payının teslim edilmesi talebinde bulunamaz, durumu belli oluncaya kadar bu pay ayrılıp koruma altına alınır (...) İstishabın hem def'ide hem ispatta hüccet olduğunu söyleyenlere göre ise mefkud hakkında tamamen sağ hükümleri uygulanır (...); mûrisi kendisinden önce ölmüşse mirastan payını alma, aynı şekilde lehine vasiyet edilen malı alma hakkına sahip olur."107

(3) Ali Hasebullah Usûlü̈t-teşrî̀'l-İslâmî adlı kitabında, Hanefîler'e göre istishabın sadece def'ide, Şâfiîler'e göre def'ide ve ispatta hüccet sayıldığ 1 yönündeki usul ihtilafına dayalı bir örnek olarak mefkudun mirasçılı̆̆ına değinirken, "Hanefîler'e ve Mâlikîler'e göre mefkud kayıplığı sırasında ölen yakınına mirasçı olamaz (...); Şâfiîler’e ve Hanbelîler'e göre ise mirasçı olur” demekte ve payının ayrılacağından söz etmemektedir. ${ }^{108}$

(4) Züheyr Usûlü̉l-fikh adlı kitabında, istishabı delil olarak dikkate alıp almamaktan doğan birçok fürû-i fikıh hükmü bulunduğunu belirttikten sonra mefkud örneği hakkında, "Şâfiîler mefkud başkasına mirasçı olur ama ona mirasçı olunmaz, Hanefîler ise ona mirasçı olunmayacağı gibi o da başkasına mirasçı olmaz demişlerdir" şeklinde bilgi vermekte, payının ayrılacağından söz etmemektedir. ${ }^{109}$

(5) Vehbe ez-Zühaylî, Usûlül-fikhi'l-İslâmî adlı kitabında istishabın hüccet değeri hakkındaki usul ihtilafının sonuçlarından biri olarak mefkudun mirasçıllğı örneğine yer vermekte, istishabın etkisini "olumlu haklar-olumsuz haklar” şeklinde bir ayırım yaparak açıklamakta ve onun mirasçllı̆̆ ile ilgili

106 s. 28o. Yazar el-Ahvâlüşşshsiyye adlı kitabında Mısır pozitif hukukundaki durumu incelerken, "f́kıhta istishâbü'l-hâl adını verdikleri" delil uyarınca, mefkudun mirasçı olabileceği bir yakınının -onun ölümüne hükmedilmeden önce- vefat etmesi halinde, -hâkimin ölümüne hükmetmesine veya yaşadığının ortaya çıkmasına kadar- mirastaki hakkının askıya alınmış olarak devam edeceğini ifade etmektedir (s. 50o).

107 s. 229-30.

108 s. 208-209.

109 IV, 178. 
olarak şöyle demektedir: “Mâlikîler'e, Şâfiîler’e ve onlar gibi düşünenlere göre mefkud başkasından olumlu haklar elde edebilir, binaenaleyh başkasına mirasçı olur, payı ayrılır ve kendisi için yapılan vasiyet onun lehine sabit olur"; "Hanefîler'e gelince, onlara göre, mefkud için başkasına mirasçı veya vasiyet lehtarı olma gibi olumlu haklar sabit olmaz (...), kendi hakları bakımından sağ, başkalarının hakları bakımından ölü hükmündedir, (...) başkasına mirasçı olamaz, ona bir pay ayrılmaz, ölenin terekesinin taksimi sırasında o dikkate alınmaz." 110 Burada Hanefîler’in görüşünden söz edilirken, "Ona bir pay ayrılmaz, ölenin terekesinin taksimi sırasında o dikkate alınmaz" şeklinde bir bilgi verilmesi kadar bu bilgi için İbnü'l-Hümâm’n Fethu'l-kadîr isimli eserinin kaynak gösterilmesi de şaşırtıcıdır. ${ }^{111}$

Yazarın gerek birinci ${ }^{112}$ gerekse ikinci ${ }^{113}$ görüş için gösterdiği kaynaklar arasında fürû eseri bulunmamakta, zikrettiği usul eserlerinin belirtilen yerlerinde ise (Muhammed Ebû Zehre, Usûlüll-fikh, s. 286 hariç) verdiği tarzda bir bilgiye rastlanmamaktadır. ${ }^{114}$

(6) Muhammed Mustafa Şelebînnin Usûlül-fıkhi'l-İslâmî adlı kitabı da bu grupta yer almakla birlikte, diğerlerinden farklı bir sunum içermesi ${ }^{115}$ sebebiyle, -tekrardan kaçınmak üzere- makalenin sonuçlar ve değerlendirmeler içeren (8.) nolu başlığı altında ele alınacaktır.

110 II, 867-69.

111 Zira İbnü'l-Hümâm’n Fethu'l-kadîr adlı eserinde mefkudun payının koruma altına alınacağı açıkça ifade edilmiştir (bk. V, 474).

112 İbn Hazm, el-İhkâm, V, 590; el-İbhâc, III, 111; el-Medhal ilâ mezhebi Ahmed, s. 133; Nüzhetül-hâtır Şerhu Ravzatin-nâzır, I, 389 vd.; Süyûtî, Risâle fî usûli'l-fikh (Mecmûatü resâil), s. 76; Miftâhu'l-vüsûl ilâ binâil-fürû‘ alâl-usûl, s. 189; Muhtasaru İbni'l-Hâcib, S. 217.

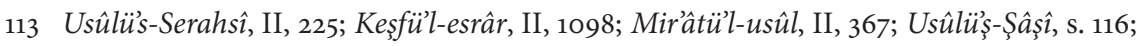
I'lâmü'l-muvakkî̀n, I, 339; el-Medhal ilâ mezhebi Ahmed, s. 134; Şerhu'l-Mahallî alâ cemi'l-cevâmi', II, 285; Şerhu'l-Adud alâ Muhtasari'l-Müntehâ, II, 284; Ebû Zehre, Usûlül-fikh, s. 286.

114 Burada söylenenler içinde sadece "Mâlikîler'e, Şâfiîler'e ve onlar gibi düşünenlere göre payı ayrılır” bilgisi doğrudur. Buna karşılık yazar Usûlül-fıkh isimli kitabında (Trablus 1990), Hanefîler'in müteahhirînine göre mefkud için başkasına mirasçı ve vasiyet lehtarı olma gibi olumlu hakların sabit olmayacağını, fakihlerin çoğunluğuna göre ise mefkudun başkasından olumlu haklar elde edebileceğini yani başkasına mirasçı olacağını ve kendi lehine yapılan vasiyetin sabit olacağını ifade etmiştir (s. 10911). Görüldüğü üzere bu kitapta çoğunluk görüşü verilirken sadece "mirasçı olacağı" belirtilmekte, payının ayrılacağından da söz edilmemektedir.

115 s. $339-44$. 


\subsection{Fıkıh Usulü Öğretimindeki Yanlış Ezbere Dolaylı Destek Sağlanmasına Örnekler}

(1) Abdülvehhâb Hallâf Mesâdirü̈t-teşrî̀'l-İslâmî fîmâ lâ nassa fîh adlı kitabında, Hanefîler'e göre istishabın def'ide hüccet olmakla birlikte ispatta hüccet olmadığını ve onların bu anlayışının mefkud hakkında verdikleri hükümle açıklığa kavuştuğunu belirttikten sonra bu örnekle ilgili olarak şunları yazmaktadır: "Mirasçıları onun terekesinin kendilerine taksim edilmesini isterlerse yaşadığı sabit olduğundan istishap uyarınca bu talepleri reddedilir. (...) Fakat mefkudun da vârisi olduğu kardeşi vefat ettiğinde, mefkudun kayyımı -istishaba göre sağ olduğu gerekçesine dayanarak- mefkudun mirasını talep etse, bu onun mirasçıllğı için hüccet olmaya elverişli görülmez. Yani mefkud fiilen vâris olmaz, ancak payı emanet olarak koruma altına alınır, sağ olduğu ortaya çıkarsa ayrılan payını miras olarak alır..."116 Aynı yazarın İlmü usûlil-fikh ve hulâsatü târîhit-teşrîi'l-İslâmî adlı kitabında da aynı bilgiye daha kısa biçimde yer verilmiştir. ${ }^{117}$

Hanefîler'in bu meseledeki yaklaşımını fürû hükümlerine uygun olarak veren bu anlatım tek başına okunduğunda herhangi bir sorun içermemekte, aksine birçok yayında kapalı kalan noktaları açıklığa kavuşturmaktadır. Ne var ki istishap delili ile ilgili görüş ayrılı̆̆ının ele alındığı ve Hanefîler’in istishabı def'ide hüccet saymakla birlikte ispatta hüccet saymadıklarının açılklandığ bir bağlamda bu örneğin sadece Hanefîler üzerinden işlenmesi, bu meselede karşı görüş bulunduğunu düşündürebilir ve buradan istishabı hem def'ide hem ispatta hüccet sayanların (özellikle Şâfiîler) mirasçı olacağ 1 kanaati taşıdıkları sonucu çıkarılabilir.

(2) Bedrân Ebü'l-Ayneyn Bedrân Usûlüll-fikhi'l-İslâmî adlı kitabında istishap hakkında farklı görüşlere ve delillerine genişçe yer verdikten sonra bu konudaki görüş ayrıllğıının fürû-i fikıhtaki örneklerine değinirken, müteahhirîn Hanefîler' in istishabı sadece def'ide hüccet saydığını ama ispatta hüccet saymadığııı, bunun sonucu olarak mefkudun -hakikaten veya mahkeme kararıyla- ölümüne hükmedilmeden önceki dönemde malına vâris olunamayacağı gibi kendisinin de bu dönemde bir yakını öldüğünde ona vâris olamayacağını ve durumu belli oluncaya kadar payının ayrılıp koruma altına alınacağını ifade etmektedir. ${ }^{118}$ Bir önceki maddede söylenenler bu kitap için de geçerlidir.

116 s. $153-54$.

117 s. 101-102.

118 s. 221-23. 
(3) Muhammed Mustafa ez-Zühaylî, el-Vecîz fì usûli'l-fikhi'l-İslâmî adlı kitabında istishabın hüccet değeri konusunda değişik görüşler bulunmakla birlikte bunlardan ikisinin önemli olduğunu, birinci görüşün sahibi olan Mâlikîler, Hanbelîler, Şâfiîler' in çoğunluğu ve Zâhirîler'e göre -delil bulunmadığındahem def'ide hem ispatta hüccet olduğunu; ikinci görüşün sahibi olan Hanefî mezhebine göre hüccet olmadığını, ancak muhakkik Hanefîler' in çoğunluğuna göre def'ide geçerli hüccet olmakla birlikte ispatta olmadığını ifade ettikten sonra bunu şöyle örneklendirmektedir: "Mesela mefkudun halen yaşadığına dair istishap deliline dayanmak böyledir; onun öldüğüne dair iddiayı def'ide, dolayısıyla vârislerinin onun mallarını paylaşmasını engelleme hususunda istishap hüccet olmakla birlikte olmayanın ispatında hüccet olmaz, binaenaleyh o esnada vefat eden mûrisine mirasçıllğ̆1 sabit olmaz." ${ }^{119} \mathrm{Bu}$ anlatım, daha öncekilerdekinden farklı olarak payının ayrılacağından söz edilmeyip, "O esnada vefat eden mûrisine mirasçılığ sabit olmaz" bilgisiyle yetinilmesi sebebiyle, yanlış ezbere daha belirgin bir dolaylı destek sağlayabilir.

(4) Mustafa Dîb el-Bugā Usûlü̉l-fikhi'l-İslâmî: Dirâse âmme adlı kitabında, "Hükmü İstishaba Dayanan Meselelerden Biri: Mefkudun Mirasçılı̆̆ı" başlı̆̆ını açıp iki hükmü birbirinden ayırt etmektedir: "a) Alimler -vefatı sabit oluncaya kadar- terekesinin taksim edilmeyeceği hususunda ittifak etmişlerdir (...). b) Daha önce yaşadığ kesin olarak biliniyorsa, onun kendisine mirasçı olabileceği kimselerden biri öldüğünde, yaşadı̆̆ı kesin olarak bilindiği durumda onun için ayrılan pay ayrılır mı? Fakihlerin çoğunluğu (cumhur) bu görüşe sahiptir; demişlerdir ki: Ölü veya sağ olduğu bilininceye, yahut baskın ihtimale göre akranlarının yaşayamayacağı süre geçinceye kadar payı koruma altına alınır."120 Verilen bilgide bir yanlışlık bulunmamakla birlikte, bu anlatım mefkudun payının koruma altına alınacacağı hususunda görüş ayrılığı bulunduğu izlenimini verdiğinden, yaygın bilgiyi dolaylı olarak destekleyici nitelikte sayılabilir. Kaldı ki (7.) nolu başlıkta açıklanacağı üzere Bugā başka bir kitabında Hanefî mezhebindeki görüşü, "Mirasçısı olduğu bir kimse öldügünde ona (mefkud) bir pay ayrılmaz, tereke ölenin mirasçları arasında taksim edilirken o dikkate alınmaz" şeklinde aktarmıştır.

(6) Abdülkerîm b. Ali b. Muhammed en-Nemle el-Mühezzeb fî usûlill-fikh el-mukāren adlı kitabında istishabın hüccet değeri ile ilgili iki ana görüşe, görüş sahiplerine ve delillerine yer verdikten sonra, birçok fürû meselesini etkilemiş olması itibariyle ihtilafın esasa ilişkin olduğunu belirtmekte ve mefkud örneğini şöyle açıklamaktadır: "Mefkud mirasçı olur mu ve ona mirasçı

119 s. $260-61$.

120 s. $120-21$. 
olunur mu? İşte bu meselede iki görüş ortaya konmuştur: a) Mefkud başkasına mirasçı olur, ama ona mirasçı olunmaz. b) O mirasçı olamaz ve ona mirasçı da olunmaz."121 Burada yanlış ezbere güçlü bir destek sağlandığı açıktır.

\subsection{Fıkıh Usulü Öğretimindeki Yanlış Ezbere Dikkat Çeken Bir Örnek}

Zekiyyüddin Şa ‘bân’’n Usûlüll-fikhi'l-İslâmî adlı kitabı, görebildiğimiz yakın dönem fıkıh usulü ders kitapları içinde, belirtilen yanlış ezberi tekrar etmediği gibi bu yanlışlığa açık biçimde dikkat çeken tek örnektir. Bu kitapta yer alan bilgi şöyledir:

$\mathrm{Bu}$ kurala göre fakihler, kaybolmuş ve sağ olup olmadığı bilinmeyen 'mefkud' hakkında şu sonuçlara varmışlardır: Ona ait olduğu bilinen haklar konusunda -öldügüne dair delil bulunmadıkça- sağlara uygulanan hükümler uygulanır. Malları mirasçıları arasında bölüştürülmez (...). Çünkü kaybolduğu sırada onun yaşadığı yakînen bilinmekteydi; o halde öldüğüne dair delil bulununcaya kadar, 'sağ olma' vasfının devam ettiğine hükmedilir.

Fakat mefkudun kendisinin de mirasçısı olduğu yakınlarından biri vefat ederse, terekedeki paya mâlik olduğuna hükmedilmez; hayatta olup olmadığı ortaya çıkıncaya kadar bu pay ayrılır ve mefkudun hakkı askıda tutulur. Bunun sebebi şudur: Mirasçılık sıfatı ancak mûrisin öldüğü sırada sağ olduğu bilinen kişi için sabit olur; oysa mefkudun bu yakını öldügünde sağ olup olmadığı bilinmemektedir. Öyleyse o sırada hayatta olduğu kesin olarak ortaya çıkıncaya kadar onun mirasçılığına hükmedilemez.

Yazar düştügü dipnotta bu meseledeki yanlış bilgiye şöyle dikkat çekmektedir:

Bu hükümde Hanefîler ile Şâfiîler arasında ihtilaf yoktur. Usul kitaplarında mefkudun Hanefîler'e göre mirasçı olamadığı Şâfiîler'e göre ise mirasçı olduğu yönünde bilgi verilmesi ve bunun söz konusu mezheplerin istishabın hüccet değeri hakkındaki ihtilafından doğmuş meselelerden biri olarak takdim edilmesi, Şâfiî fikhının güvenilir eserlerinde belirtilen görüşe aykırı düşmektedir. ${ }^{122}$

Yazarın mefkud örneği ile ilgili doğru bilgiyi ve değerlendirmeyi özlü bir biçimde verdikten sonra koyduğu, "Şâfiîler'e göre ise mirasçı olduğu yönünde

121 III, 963-66.

122 s. 212. 
bilgi verilmesi (..) Şâfiî fıkhının güvenilir eserlerinde belirtilen görüşe aykırı düşmektedir" şeklindeki not, hakikati yansıtmakla birlikte, Şâfiî fikıh eserleri hususunda ihtiyatlı bir ifade kullandığı görülmektedir. Bu meseleyi özel olarak incelemeyi üstlenmemiş olması sebebiyle böyle bir ifade kullanması tabiidir. Ancak biz araştırmamız boyunca Şâfiîler'e göre mefkudun -kayıplığ 1 döneminde ölen- yakınına mirasçı olacağı yönünde bir bilgiye hiçbir Şâfiî fıkıh eserinde rastlamadığımızı belirtebiliriz.

\section{Fıkıh Usulü Ders Kitapları Dışındaki Bazı Çağdaş Yayınlarda Mefkudun Mirasçılığı Meselesi}

(1) Ali Seyyid Hasan el-Ahkâmü'l-hâssa bi'l-mefkūd: Dirâse mukārene beyneş-şerîati'l-İslâmiyye ve'l-kānûneyni'l-Misrî ve'l-Fransî adlı mukayeseli hukuk bakımından yararlı çalışmasında, mefkudun kayıplığı esnasında vefat eden yakınına mirasçı olup olamayacağı meselesini ele alırken gerek klasik gerekse çağdaş eserlerdekinden farklı bir sunum yapmakta, "Mefkudun Başkasının Terekesindeki Haklarının Muhafazası" başlığını açarak, "Şâfiîler ile Hanbelîler'in görüşü" ve "Hanefîler ile Mâlikîler’in görüşü” şeklinde iki görüşten söz etmekte ve bu görüşleri açıklarken "Mirasçı olur" veya "Mirasçı olamaz" ibarelerini kullanmamakta, "Kaybolduktan sonra mûris veya vasiyetçisinin ölmesi durumunda -ister miras ister vasiyet olarak- ayrılan pay mefkudun mallarına eklenir mi?" ${ }^{23}$ sorusuna İslam hukukunda iki farklı cevap verildiğini belirtip bu görüşleri açıklama cihetine gitmektedir.

Öncelikle belirtmek gerekir ki, yazarın Şâfiîler'in görüşü için bu mezhebin kaynaklarından gösterdiği ${ }^{124}$ tek eser olan, Ravzatüt-tâlibîn'deki bilgiler Şâfiîler'e de nispet edilen bilgilerle örtüşmemekte; Şâfiîler ile Hanbelîler'in bu konularda aynı görüşü paylaştıkları varsayımından yola çıktığı ama daha çok Hanbelî mezhebine ait kaynaklardaki anlatımları esas aldığı; mûrisinin ölümü sırasında mefkudun sağ veya ölü olduğunun anlaşılması durumunda dört mezhebe göre hüküm aynı olduğu halde, bu hususun kesin olarak bilinememesi durumunda onun için ayrılan payın ne olacağına dair görüş farklılığına bağlı bilgilerin etkisi altında bir tasnif yapma cihetine gittiği izlenimi edinilmektedir.

Yazar ayrıca dipnotta, "Mefkudun mûrisinin terekesi mefkudun sadece sağ olduğu farzedilerek taksim edilir" ve "Tereke mevcut mirasçılar arasında taksim edilir; zira o andaki mirasçıların yaşadığ 1 kesindir, mefkudun yaşadığ 1 ise şüpheli olduğuna göre o vâris olamaz" şeklinde iki görüş daha bulunduğunu söylemektedir. Oysa (5.) nolu başlıkta açıklandığı üzere, atıfta bulunduğu eserlerde (Nevevînin Ravzatü't-tâlibîn'i, Muvaffakuddin İbn

123 s. 64 .

124 s. 64 , dipnot 53 . 
Kudâme'nin el-Muğnîsi ve Ebü'l-Ferec İbn Kudâme'nin eş-Șerhu'l-kebîr'i) yer alan bu bilginin, mefkuddan başka vârislerin bulunması durumunda mefkudun payı ayrılırken diğer vârislerin paylarının nasıl hesaplanacağına ilişkin olduğunu dikkatten kaçırmış olmalıdır.

Yine bu çalışmada, Hanefîler ile Mâlikîler aynı grupta ele alınırken, Mâlikîler'in görüşü için bu mezhebe ait bir tek esere dahi atıf yapılmadığı görülmekte, ${ }^{125}$ bibliyografyasında üç Mâlikî kaynağa yer verilmiş olsa da esas gerekli olan bu yerde onların kullanılmadığı anlaşılmaktadır.

(2) Muhammed Fethî ed-Düreynî Buhûs mukārane fìl-fikhil-İ́slâmî ve usîlih adlı kitabının "Nazariyyetü’l-istishâb fî usûli'l-fıkhi'l-İslâmî el-mukāren" başlığını taşıyan bölümünde, Serahsînin usul eserindeki açıklamaları esas alarak, onun (keza müteahhirîn Hanefîler'in) istishap ile ilgili görüşlerini mefkud örneği üzerinden açıklarken, bunun mutlak bir hüccet olmadığı, def'ide geçerli olmakla birlikte ispatta geçerli sayılmadığı, bu sebeple mefkudun mûris olmayacağı gibi vâris de olamayacağı bilgisini bazı anlatım farklılıklarıyla birkaç defa tekrar etmekte; ${ }^{126}$ onların usulünde Şâfiîler' in zıt görüşte olduklarının belirtildiğini de şöyle ifade etmektedir: "Açıkladığımız üzere, özellikle İmam Serahsînin (keza müteahhirîn Hanefîler' in) usulünde yerleşik kural şudur: İstishap, Şâfiiller'e göre hem def'ide hem ispatta geçerli mutlak bir hüccet olmasına karşılık (bize göre) sadece def 'ide hüccettir, ispatta hüccet değildir.” ${ }^{127}$

"Usulcülere Göre İstishabın Hüccet Değeri” başlı̆̆ı altında müteahhirîn Hanefîler' in yaklaşımını eleştiren ${ }^{128}$ Düreynî daha sonra bu görüşe muhalif olduklarını belirttiği Şâfiîler'in yaklaşımını açılamakta ve "İște bizim nazarımızda da tercihe şayan olan görüş budur" demektedir. ${ }^{129}$ Burada yazar mefkud örneğini tekrar etmemekle birlikte daha önce mefkud örneği bağlamında, "Buna karşılık Şâfiîler'e göre hem def'ide hem ispatta olmak üzere mutlak bir hüccettir" ifadesini kullandığ $1^{130}$ dikkate alındığında Şâfiîler'in mefkudun kayıp olduğu dönemde vefat eden yakınına mirasçı olacağı görüşünde oldukları şeklindeki yaygın bilgiyi esas aldığı ve kendisinin de bu görüşü tercih ettiği anlaşılmaktadır. Zaten bu tercihini belirttiği cümle için düştügü dipnotta Ali Hasebullahỉn Usûlü̉t-teşrîìl-İslâmî isimli eserine atıfta bulunmaktadır ki, belirtilen eserde bu bilgi açık biçimde yer almıştır. ${ }^{131}$

\footnotetext{
125 s. 66 , dipnot 55.

126 I, $375-78$.

127 I, 378.

128 I, 395-401.

129 I, 403-404

130 I, 378.

131 s. 208-209.
} 
İslam hukuku alanında kıymetli çalışmalarıyla ve kavram inceliklerine dikkat etmesiyle tanınan Muhammed Fethî ed-Düreynînin anılan çalışması istishap delilinin mahiyeti ve sınırlarının belirlenmesi ile ilgili önemli analizler içermekle birlikte, araştırma konumuz hakkında yaptığı nakillerin ve değerlendirmelerin beklenen titizlikten uzak olduğu, dolayısıyla fikıh usulü yazımında ve öğretimindeki yanlış ezberi perçinlemeye katkı sağlayan bir işlev üstlendiği söylenebilir. Şöyle ki:

a) Düreynînin bu incelemesinin bibliyografyasında ve dipnotlarında (Mecelletü’l-ahkâmi'l-adliyye bir tarafa bırakılırsa) hiçbir fürû eserinin yer almadığı görülmektedir. Bölüm başlğ̆ına "usûl-i fıkıhta" kaydını koyduğu için, yazarın incelemesini ağırlıklı olarak usul eserleri üzerinden yürütmesi makul olsa da, özü itibariyle bir fürû konusu olan "mefkudun mirasçılı̆̆ı" meselesinde fürû eserlerinin tamamen göz ardı edilmesi haklılık taşımaz. Özellikle bu mesele hakkında mezheplere görüş nispet ederken onların fürû kaynaklarına dayanılması beklenir. Nitekim anılan meselenin fürû eserlerindeki çözümünden soyutlanarak incelenmesi sebebiyle, fikıh mezheplerinin mefkud için mûrisinin terekesinden pay ayrılması şeklindeki çözüm üzerinde ittifaka yakın bir fikir birliği bulunduğu halde bu bilgi okuyucuya verilememiştir.

b) Yine bölüm başlığında "mukāren" (karşılaştırmalı) kaydı konduğu ve mefkudun mirasçılığı meselesinde Şâfiîler' in görüşü can alıcı noktayı teşkil ettiği halde -bu meselede- hiçbir Şâfiî usul kaynağına dayanılmamıştır. Üstelik yazar kendisinin Şâfiîler' in görüşünü tercih ettiğini belirtmekte ve "Şâfiîler’e mefkudun vefat eden yakınına vâris olacağı” görüşünü nispet eden bir kitaba (Ali Hasebullahỉn Usûlü̈t-teşrîìl-İslâmî) atıfta bulunmaktadır. ${ }^{132} \mathrm{Bu}$ ise iki açıdan eleştiriye açıktır: aa) Yazarın kendi tercihini belirttiği bir durumda sadece kaynak göstermesi anlamlı olmayıp, bunu Şâfiîler'in bu görüşte olduğunu teyit için yapıyorsa, "bu görüş için bk." gibi bir kayıt koyarak, o yazarın görüşüne katıldığını belirtmek istiyorsa, "aynı görüş için bk.” gibi bir açıklamada bulunarak atıfta bulunması beklenirdi. bb) Ali Hasebullah anılan eserinin metninde (özellikle mefkud örneğini açıklarken) Şâfiîler’in görüşünü tercih eden bir ifade kullanmadığı gibi aksine Hanefîler'in görüşüne ağırlık vermekte, dipnotta ise iki mezhebin görüşlerini ayrı ayrı açıklamaktadır. ${ }^{133}$

c) Diğer taraftan, Düreynînin usulcülerin istishap çerçevesinde zikrettikleri birçok kural ve örnek hakkında -net bir üslupla- eleştirilerde bulunduğu dikkate alındığında, konuya ilişkin fürû kaynaklarıyla da ilgilenme fırsatı 
bulsaydı, mefkudun vefat eden yakınına mirasçılığı meselesinin istishap deliline bağlanarak açıklanmasını da eleştirmesi beklenirdi.

d) Serahsînin usul eserini esas alarak mefkud örneğine geniş yer veren yazarın sunumundan Şâfiîler’e göre mefkudun mirasçı kılındığı anlamı çıkmaktadır. Oysa atıfta bulunduğu yerde Serahsînin mefkud örneği konusunda karşı görüşe değinirken kullandığı ifade, "Şâfiî̀nin bazı ashabı" șeklindedir (II, 224-25).

(3) Vehbe ez-Zühaylînin el-Fıkhül-İslâmî ve edilletüh adlı geniş hacimli fürû kitabının mefkudun mirası ve mirasçılığı ile ilgili bölümünde, usul öğretimindeki yanlış ezberin etkisinden kurtulamadığı ve -sunumda bazı farklılıklar olsa da- fikıh usulü kitabındaki yanlış bilgileri tekrar ettiği görülmektedir. ${ }^{134}$ Burada farklı olarak, mefkudun Hanefîler'e göre mirasçı olamayacağ 1 , (Şâfiîler'in de içinde bulunduğu) çoğunluğa göre ise mirasçı olacağı bilgisinin verilmesini takiben konan "mefkudun mirasçı oluş şekli" başlı̆̆ altında mefkud için ayrılacak pay ile ilgili değişik durumlar, ardından sağ veya ölü olduğunun anlaşılmasına ilişkin hükümler açıklanmış olmakla birlikte birinci görüşü takiben mefkud için mirastan pay veya vasiyet edilen malın ayrılması konusundan hiç söz edilmediği ve işaret edilen bilgilere ikinci görüşten sonra yer verilmiş olduğu için, okuyucu Hanefîler'de mefkud için pay ayırma uygulamasının olmadığı gibi bir izlenim edinmektedir (ki zaten fikıh usulü kitabında bu yanlış bilgiyi açıkça ifade etmiştir). Yine bu kitabın "el-Mefkūd" başlığını taşıyan faslında, Hanefîler'e göre mefkudun akrabalarından birine mirasçı olamayacağı, sanki ölüymüş gibi kabul edileceği belirtildiği halde, devamında -bu bilgiyle bağı kurulmaksızın- mefkudun payının ayrılmasından söz edilmesi, buradaki anlatımı fikrî insicamdan mahrum hale getirmektedir. ${ }^{135}$

Yazarın fikıh usulü ile ilgili kitabında olduğu gibi burada gösterdiği kaynaklar arasında fürû eseri bulunmamakta, zikrettiği usul eserlerinin belirtilen yerlerinde ise ${ }^{136}$ verdiği tarzda bir bilgiye rastlanmamaktadır. Diğer taraftan yazar anılan kitabın V ve VIII. ciltlerinde mefkud hakkındaki hükümler için genel atıfta bulunurken ${ }^{137}$ bazı fürû eserlerini ${ }^{138}$ kaynak göstermiş olmakla

134 VIII, 421-22.

$135 \mathrm{~V}, 784$.

136 Hanefîler'in görüşü için gösterdiği kaynaklar şunlardır: Usûlü’s-Serahsî, II, 225; Mir'âtü'l-usûl, II, 367; Keşfül-esrâr, s. 1098. Çoğunluğun görüşü için gösterdiği kaynaklar şunlardır: Muhtasaru İbni'l-Hâcib, s. 217; Tilimsânî, Miftâhu'l-vüsûl ilâ binâi'lfürû‘ alâ'l-usûl, s. 189; Sübkî, el-İbhâc, III, 111; Şerhu'l-Mahallî alâ Cem'i'l-cevâmi', II, 285; el-Medhal ilâ mezhebi Ahmed, s. 133; Șerhu Ravzatìn-nâzır, I, 389; İbn Hazm, el-İhkâm, V, 590; Muhammed Takıyyü'l-Hakîm, s. 454.

137 V, 784; VIII, 419.

138 el-Mühezzeb, II, 146; Keşşâfül-kınâ', V, 487 vd.; eş-Şerhu's-sagìr, II, 694; es-Sirâciyye, 
birlikte, bu eserlerin ilgili yerlerinde Hanefîler'e göre mefkudun -kayıplı̆̆ sırasında ölen- yakınına mirasçı olamayacağına, Şâfiîler'e göre ise mirasçı olacağına dair bir bilgiye rastlanmamaktadır. Yazar bu eserleri kaynak gösterirken buralarda "istishap" ve/veya "mefkud"dan söz edilmiş olmasını yeterli görmüş olmalıdır.

Daha ilginç olan bir durum, yazarın sırf Şâfiî mezhebi hükümlerini derlediği (ilk baskı tarihi 2008 olan) el-Fıkhü̧s-Şâfiì el-müyesser adlı kitabında, "Mefkudun mirasçısı olduğu kimsenin vefatı halinde, ölüm esnasında mefkudun sağ mı ölü mü olduğu belli oluncaya kadar sadece onun payını ayırırız (koruma altına alırız)" diyerek ${ }^{139}$ Şâfiî mezhebindeki doğru bilgiyi yansıtan bir ifade kullanmış olmasıdır. Mukayeseli usul ve fürû kitaplarında Şâfiî mezhebine nispet edilegelmiş yanlış bilgiye -muhtemelen bu örnekle özel olarak ilgilenememiş olması sebebiyle- yer veren yazarın, daha sonraki bir tarihte yayımladığı ve özel olarak Şâfiî mezhebi hükümlerini mercek altına aldığ 1 kitapta doğru bilgiyi aktarmış olması olumlu bir durum olup bizzat kendisi tarafından yapılmış bir tashih sayılır. Ancak diğer kitaplarının yeni baskılarında gerek bu bilginin gerekse Hanefîler hakkındaki yanlış bilginin düzeltilmesi gerekir.

(4) Abdülmün'im Fâris Sekkā, mefkudun mirasçı olması konusundaki görüşleri mezheplerin çok sayıdaki bilgi kaynaklarına dayanarak ve farklı durumları ayırt ederek derli toplu sunmaya çalışması açısından yararlı olan Ahkâmül'-gāib ve'l-mefkūd fi'l-fikhi'l-İslâmî: Dirâse mukārene adlı kitabında, önce Hanefîler'e göre mefkudun -kayıplığı döneminde- vefat eden yakınına mirasçı olamayacağı, Şâfiîler'e göre ise mirasçı olacağı yönündeki yaygın bilgiyi ve usulî gerekçelerini tekrar etmekte, hatta -asla sadık sayılamayacak atıflarda bulunarak- mirasçı olacağı görüşünü (Şâfiîler’in de içinde olduğu) cumhura nispet etmekte; ikinci aşamada ise fürû eserlerinde yer alan gerçek fikhî sonuçlara intikal etmektedir. Yazarın ikinci aşamada mefkud için ayrılan payın âkıbeti ile ilgili değişik ihtimallere yer verirken hemen yukarısında belirttiği Hanefîler-cumhur şeklindeki ayırımın bu mesele bakımından geçerliliğinin olmadığını açıkça gördüğü ve yazdığı halde, doktora tezi düzeyindeki araştırmasında -hiçbir yorum veya eleştiride bulunmaksızın- bu iki zıt açılamaya peşpeşe yer vermesi düşündürücüdür. ${ }^{140}$

s. 221-25; er-Rahbiyye, s. 76; el-Muğnî, VI, 321-25; Muğnil-muhtâc, III, 26; el-Kavânînül-fikhiyye, s. 216.

139 II, 264.

140 s. $685-86$. 
Bu çalışmanın makalede özel olarak ele aldığımız diğer örnek yayınlarla metot açısından örtüştüğü nokta, "Onların bu meseledeki görüş ayllı̆̆ı istishabın hüccet değeri konusundaki görüş ayrılıklarının bir uzantısıdır” şeklindeki fıkıh usulü öğretiminde yaygınlık kazanmış yanlış ezberin tekrar edilmesi yanında fürû konusu olan bir mesele için fürû kaynakları yerine usul kaynaklarına atıfta bulunmakla yetinilmesi gibi ciddi bir akademik hataya düşülmüş olmasıdır. Üstelik bu bilgi için uygun usul kaynakları bulunduğu halde yazarın bu hususta da yeterli akademik titizliği göstermediği gözlenmektedir; zira (4.) nolu başlıkta açıklandığı üzere kaynak gösterdiği eserlerde (el-İbhâc fî̀şshi'l-minhâc, el-Bahrü̉l-muhît, Șerhu'l-İsnevî / Nihâyetü's-sûl şerhu Minhâci'l-vüsûl liłl-Beyzâvî) verdiği bilgiye rastlanmamaktadır. Yazar bu eserleri kaynak gösterirken buralarda "istishap" ve/veya "mefkud"dan söz edilmiş olmasını yeterli görmüş olmalıdır.

(5) Mustafa Dîb el-Bugānın, İslam hukukunun tâli kaynaklarıyla ilgili görüş ayrılıklarının sonuçlarını incelediği (ve ileriki yıllarda da bir tashihte bulunmaksızın yayımladığı) doktora tezinde, yukarıdaki örneklerden farklı olarak sadece fürû kaynaklarını esas aldığı halde -(3.) nolu başlıkta açıklandığg üzere- Hanefî fürû literatüründeki yaygın anlatımdan ilk bakışta edinilen izlenimin etkisi altında kalarak bu mezhebe ait görüşü yanlış aktardığ1 görülmektedir. Yazar mefkudun mirasçılığı meselesini özel olarak ele alırken şöyle demektedir: "Ebû Hanîfe ve arkadaşlarına göre mefkud başkalarının hakkı konusunda ölü sayılır; binaenaleyh mirasçısı olduğu bir kimse öldügünde ona (mefkud) bir pay ayrılmaz, tereke ölenin mirasçıları arasında taksim edilirken o dikkate alınmaz." Yazar Mergīnânînin Bidâyetü'l-mübtedî isimli eserindeki, "Mefkud, kayıplığı sırasında vefat eden hiç kimseye mirasçı olamaz" ifadesiyle Haskefînnin ed-Dürrü̉l-muhtâr adlı eserinde yer alan aynı anlamdaki ifadeyi bu bilginin dayanağı olarak göstermektedir. ${ }^{141}$ Diğer taraftan yazar farklı görüşlerin delillerini ayrı bir başlık altında ele alırken Hanefîler'in görüşünü izah için el-Hidâye'deki ve İbn Âbidîn'in Hâşiye’sindeki bazı ifadelerden destek almaya çalışmakta, fakat Serahsînin el-Mebsût'unda -Şâfiîler ve Mâlikîler'de olduğu gibi- mefkudun payının ayrılacağına dair bir ifade gördüğünü söyleyip anılan eserden bir nakilde bulunduğu halde, "Başkasının malı konusunda sağ sayılmaz" ibaresinin uyandırdığı tereddüt üzerine, "Bu ifade ile payının hemen verilmeyip koruma altına alınacağı kastedilmiş olmalıdır" şeklinde bir tahmin yürütmekle yetinmektedir. ${ }^{142}$

141 Eserül-edilleti'l-muhtelef fîhâ, s. 220-21.

142 s. 223. Diğer taraftan yazar Mâlikî, Şâfiî ve Hanbelî mezheplerindeki mefkudun payının ayrılmasına ilişkin yaklaşımı ilgili eserlerden iktibaslar yaparak doğru biçimde yansıtmış olmakla birlikte, bu konudaki görüş ayrılığını kendi ifadeleriyle özetlerken, 
(6) Y. Linant de Bellefonds imzasını taşıyan Encyclopédie de l'Islam'daki ${ }^{143}$ ve The Encyclopaedia of Islam'daki ${ }^{144}$ "Istishāb" maddelerinde bir fürû eseri olan Kâsânînnin Bedâiu's-sanâi adlı eserine ${ }^{145}$ dayanılarak istishabın rolü konusunda Hanefîler ile Şâfiîler arasındaki görüş ayrıllı̆ı̆ı açıklamak üzere şüf'a iddiasıyla ilgili ihtilaf örneğinin verilmesi isabetli olmakla birlikte, Kâsânînnin Hanefîler’e göre istishâbü'l-hâlin başkasını bağlamaya elverişli bir delil olmadığını belirtmek üzere, "mefkudun hayatta oluşu gibi" ibaresini kullanmış olmasından hareketle, "Böylece bu mezhepte (Şâfiîler'de), ölümü tespit edilemeyen bir mefkud, mirasçı olur; fakat Hanefî hukukuna göre olamaz" sonucuna ulaşılarak metne sadık olmayan bir çıkarım yapılmıştır. Şöyle ki: Yukarıda açıkladığımız üzere bazı Hanefî usulcüler, "Mefkud Hanefîler’e göre yakınına mirasçı olamaz, ama Şâfiîler'e göre mirasçı olur” şeklinde bir iddia ileri sürseler de -bu iddiaya usul eserinde yer verenler de dahil olmak üzere- Hanefî fürû müellifleri mefkud ile ilgili hükümleri incelerken aynı iddiayı tekrar etmekten kaçınmışlardır. Aynı şekilde -az yukarıda açıklandığı üzere- Kâsânînin de mefkudun mirasçıllğı meselesini özel olarak ele ald1ğ̀ bölümde Şâfiîler'in görüşüne değinmemeyi tercih ettiği görülmektedir. ${ }^{146}$ Kâsânînin burada (şüf'ayı incelerken) kullandığı "mefkudun hayatta oluşu gibi” şeklindeki ibare, Hanefîler’e göre mefkudun kayıplığı öncesinde (ve tabii mûrisinin henüz sağ olduğu dönemde) hayatta olduğunun bilinmesinin başkalarının hakkını etkileyecek bir delil sayılmadığını, dolayısıyla onun mirasçılığına hükmedilmediğini ifade etme ile sınırlıdır; yoksa Şâfiîler’in mefkudu mirasçı saydıklarına dair bir mâna içermemektedir.

(7) Th.W. Juynboll imzasını taşıyan MEB İslâm Ansiklopedisindeki "İstishâb" maddesinde ise, ${ }^{147}$ araştırma konumuzu oluşturan ezberin tekrarı mahiyetindeki şu bilgi yer almaktadır: "Msl. hanefîlere göre, gâip kendisinin gaybûbeti zamanında tahakkuk eden bir mirasta şer'î vâris sayılamaz; fakat şâfi'îlere göre, bu mirasa ehliyetli sayllır; çünkü bunlar onun gaybûbeti esnâsında da yeni haklar iktisâp edebileceğini kabûl ederler."

(8) İlerideki yıllarda adı Mevsûatül-fikhil-İslâmî şeklinde değiştirilen Mevsûatü Cemâl Abdinnâsır fill-fikhil-İslâmînnin "el-İstishâb" maddesinde

- "sağ" kabul etmenin sonuçlarını dikkatten kaçırarak- İmam Mâlik ve Şâfî̂nnin mefkudu gerek kendi hakları gerekse başkalarının hakları konusunda "sağ" kabul ettiklerini söylemektedir (s. 220).

143 IV, 281-82.

144 IV, 269.

$145 \mathrm{~V}, 14$.

146 Bedâi', VI, 196.

147 V/2, s. 1221. 
istishap ile ilgili görüş ayrılığına dayalı fürû örneklerine değinilirken şu bilgiye yer verilmiştir: "Mefkudun mirasçılı̆̆ı: Onun gaipliği sırasında (yakınlarından) biri ölürse, Şâfiî̀ye göre -istishap yoluyla yaşadığının bilinmesine binaen- mirasçı olur; Hanefîlere göre ise mirasçı olamaz, zira istishap yoluyla onun hayatta olduğunun kabul edilmesi haklar kazanmasını gerektirmez." ${ }^{148}$ Burada kaynak olarak sadece Hanefî usul eserlerine dayanılmış, hiçbir Hanefî fürû ve Şâfiî usul veya fürû eserine atıfta bulunulmamıştır.

\section{Mefkud Örneği İncelemesinin Düşündürdükleri}

Buraya kadar istishap delilinin "istishâbü’l-hâl" diye anılan türü işletilirken özellikle Hanefîler ile Şâfiîler arasında görülen yaklaşım farklılığını açıklamak üzere, "Hanefîler'e göre mefkud -kayıplığı sırasında ölen- yakınına mirasçı olamaz, ama Şâfiîler'e göre mirasçı olur” şeklinde yaygın biçimde kullanılan örneğin bu mezheplerin kaynakları tarafından doğrulanıp doğrulanmadığını incelemeye çalıştık. Bu başlık altında, belirtilen inceleme ışığında ulaştı̆̆ımız sonuçlar yanında, dikkatimizi çeken fikıh/fıkıh usulü yazımında ve öğretiminde karşılaşılan bazı metot sorunları ile bunların hukuk tefekkürünün gelişimi üzerindeki olumsuz etkileri özetlenecektir.

(1) Gerçekte olmadığı halde ihtilafın varsayılmasının sakıncaları:

Konu bütüncül bir bakışla incelendiğinde, gerek Hanefî gerekse Şâfiî mezhebine (hatta dört mezhebe) mensup fakihlerin mefkudun mirasçılığ 1 meselesinde sağlam bir muhakeme yürüttükleri, hemen hepsinin bir taraftan sağ mı ölü mü olduğu bilinmeyen bir kimseye diğer mirasçlara uygulanan hükmün uygulanamayacağı, diğer taraftan da hayatta olabileceği ihtimalinden hareketle -durumu açıklığa kavuşuncaya kadar- payının ayrılması/koruma altına alınması gerektiği kanaatine sahip oldukları, hatta İslam miras hukuku kuralları gereği mevcut mirasçılar tablosuna göre alabileceği en yüksek payın hesap edilmesine özel önem atfettikleri, dolayısıyla konunun esasına ilişkin bir görüş ayrılığının bulunmadığı gözlenmektedir.

Mirasçılığıı halefiyet anlamı taşımasına, yani normal şartlarda terekenin kendiliğinden mirasçıların mülkiyetine geçtiğinin kabul edilmesine mukabil mefkudun payı üzerinde fiilen tasarrufta bulunulamaması vb. sorunlardan hareketle bazı hukukî analizler yapılarak farklı değerlendirmelere ulaşılabilirse de, bu meselenin fikıh usulündeki istishap tartışmalarında söz konusu olan "mevcut durumun/hakların korunması" (def'i) ve "yeni bir hakkın kazanılması" (ispat) hallerinin ayırt edilmesi bağlamına taşınmasının isabetli 
olmadığ açıktır. Bir başka anlatımla, mefkudun, hayatta olduğu kesin olarak bilindiği dönemde mevcut olan haklarının korunacağı, mesela -durumu açıklığa kavuşuncaya kadar- mallarının mirasçılarına taksim edilmeyeceği hükmü gerekçelendirilirken istishap delilinden yararlanılması makul olmakla birlikte; yaşayıp yaşamadığı bilinmediğine göre yeni bir hak elde edemeyeceği, dolayısıyla bu dönemde vefat eden yakınına mirasçı olamayacağ șeklinde bir önermeye ulaşılmasının, hem usul düşüncesi hem de fürû-i fikıhta benimsenen hüküm bakımından izahı mümkün olmayan yapay bir ihtilafı gündeme getirmiş olduğu kanaatine ulaşılmaktadır. Kaldı ki bu sunum aynı zamanda -karşı görüşün sahibi olarak gösterilen- Şâfiî mezhebinde mefkudun (mutlak biçimde) mirasçı sayıldığı şeklinde bir iddiayı da içermektedir; oysa bu mezhebin gerek usul gerekse fürû kaynaklarında böyle bir bilgiye rastlanmamaktadır.

Aksine, gerek Hanefî mezhebinin gerekse Şâfiî mezhebinin temel fürû kaynaklarında (özellikle Şeybânînin el-Aslında), "mefkudun sağ mı ölü mü olduğunun bilinmediği" ve "durumu açıklığa kavuşuncaya kadar payının koruma altına alınacağı” belirtildiği, yani iki mezhebin bu konuda farklı bir yaklaşıma sahip olmadığı açıkça görüldüğü halde, fürû alanında ihtilaf varmış gibi bir sunumla usul alanında bir ihtilaf örneği üretilmiş, böylece "Mefkud Hanefîler'e göre mirasçı olamaz, ama Şâfiîler’e göre mirasçı olur" şeklinde bir yanlış ezber asırlarca varlı̆̆ını korumuştur.

Fıkıh usulü öğretiminde önemli bir görev ifa etmiş olan İbnü’l-Hümâm’n et-Tahrîr adlı usul eserinde bile, "Şâfiî̀ye göre, kaybolduğu dönemde mûrislerinden biri vefat ederse mefkud ona mirasçı olur" şeklinde bir bilginin bulunması, makalenin başlığında yer alan "yanlış ezber" ifadesinin haklılığını göstermekle birlikte, bu yanlışlığ düzeltme hususunda istisnaî bir çabaya da rastlanmaktadır. Şöyle ki: Zeynüddin İbn Nüceym (ö. 970/1563) dört eserinde Hanefîler ile Şâfiîler arasındaki istishap ile ilgili usul ihtilafını açıklarken mefkudun Şâfiîler’e göre mirasçı sayıldığını doğrudan veya dolaylı biçimde ifade ettiği halde, ${ }^{149}$ el-İstishâb risalesinde, ("şeyhimiz" diyerek)

149 a) İbnü’l-Hümâm’n anılan eserini ihtisar ederken bu örneği korumayı tercih edip, "Onlara göre mefkud mirasçı olur, bize göre olamaz" ibaresine yer vermekte (Lübbü’l-usûl muhtasarü't-Tahrîr li’bni'l-Hümâm, s. 279); b) Nesefînin eserine yazdı̆̆ şerhte Şâfiî ile Hanefîler arasındaki usule ilişkin bu görüş ayrılığına dayalı ihtilaflı fürû meselelerine örnekler verirken (İmam Şâfîìyi kastederek), "Mefkud ona göre mirasçı olur, ama bize göre olamaz" ifadesini kullanmakta (Fethu'l-gaffâr bi-şerhilMenâr, III, 24-26); c) Fürû-i fikıh ile ilgili eserinde -devamında mefkuda pay ayrılması hükmünden söz etse bile- "Başkasının hakları konusunda ölü hükmünde olduğu için başkasına mirasçı olamaz" kalıbını tekrar etmekte (el-Bahrürr-râik, V, 176-79); d) el-Eşbâh ve’n-nezâir adlı kitabında konuya ilişkin usulî görüşün fürûya 
İbnü'l-Hümâm’n et-Tahrîr'de istishabı tanitırken, "Şâfiîler'e göre mefkud mirasçı olur, bize göre olamaz" ibaresine yer vermesinin "sehiv" olduğunu söylemekte ve "Her iki mezhepte nakledilen hüküm mefkudun payının ayr1lacağı yönündedir" açıklamasını yapmaktadır. ${ }^{150} \mathrm{Ne}$ var ki, yanlış bir ezberin bozulmasında önemli bir işlev görebilecek bu risale kütüphanelerin tozlu rafları arasında kalmış, muttali olanlar arasında ise -bildiğimiz kadarıyla- bu uyarıya özel bir ilgi gösteren veya eleştirel bir bakışla bu akışa engel olmaya çalışan çıkmamıştır. Hal böyle olunca, İbn Nüceym’in bu tashihinden habersiz olarak, Ezher'de ders kitabı olarak okutulan İbnü’l-Hümâm’n et-Tahrîr adlı eseri ile İbn Nüceym'in Fethu'l-gaffâr bi-şerhil-Menâr isimli eserindeki yanlış ezberin öğrencilerin zihinlerine yerleştirilmesine devam edildiği gibi; yakın dönemlerde ders kitabı olarak yazılan çok sayıdaki fıkıh usulü kitabı ile istishap delilini veya mefkudun hukukî durumunu inceleyen birçok yayında aynı ezberin sürüp gittiği görülmektedir.

Özellikle fıkıh usulü eserlerinde yer alan birçok görüş ayrılığını iyi bir incelemeye tâbi tutan bazı alimlerin ve günümüz araştırmacılarının, "Buradaki ihtilafın konunun özüyle ilgili olmayıp lafzî olduğu anlaşılmaktadır” şeklinde bir sonuca varmaları da, gerçekte olmadığı halde ihtilafın varsayılması yoluyla gereksiz zaman kaybına yol açan durumların az olmadığını ortaya koymakla birlikte, araştırma konumuzu oluşturan meselede açık bir bilgi hatasının tekrar edilmesine dayanan yapay ihtilafin zaman kaybına sebebiyet vermenin ötesinde fikıh ve hukuk düşüncesinde eleştirel bakışı önleyici bir etki meydana getirdiği de göz ardı edilmemelidir.

(2) Fıkıh usulü ilminin manevi otoritesine teslim olmanın olumsuz etkileri:

Fıkıh ve usul ilminde temayüz etmiş ve kendilerinden sonraki fikıh ve usul-i fikıh öğretimini derinden etkilemiş Sadrüşşerîa ve İbnü'l-Hümâm gibi alimlerin fikıh usulü ile ilgili eserlerinde mefkudun -kayıplığı esnasında

yansımasıyla ilgili örnekler verirken, "Bize göre mefkud mirasçı olamaz ve kendisine mirasçı olunmaz" bilgisini vermekte (s. 83), yani son iki eserde Şâfiîler'den söz etmese bile Hanefîler'in bu meselede Şâfiîler'den farklı olduğunu dolaylı biçimde belirtmiş olmakta; kısacası -anılan yerlerde- eleştiri veya tashih cihetine gitmeden et-Tahrîr i esas aldığı görülmektedir.

150 İbn Nüceym, el-İstishâb (Meys), s. 271. Kitabı yayına hazırlayan Halîl el-Meys önceki matbu nüshada çok sayıda matbaa hatasına rastlandığını belirttiği için bu risalenin bazı yazma nüshalarını (Süleymaniye Ktp., Lâleli, nr. 3694, vr. 120'; Râşid Efendi Ktp., nr. 198, vr. $104^{\text {b) }}$ inceledik ve -gerek matbu ile yazmalar arasında gerekse yazmaların kendi aralarında- esası etkilemeyen bazı kelime farklılıkları bulunsa da yazmalardaki bilginin İbn Nüceym’in yukarıda belirtilen ifadeleriyle örtüştügünü gördük. Şu var ki İbn Nüceym İbnü’l-Hümâm’n "Şâfiî̀ye göre” ifadesini “Şâfiîler’e göre” şeklinde aktarmıştır. 
ölen- yakınına mirasçı olacağı görüşünü “açıkça" Şâfiîller’e/Şâfiî̀ye nispet edip bunu usulî bir meselede (istishâbü'l-hâl ile istidlalde) Hanefî ve Şâfiî mezhebi arasındaki ayrışma noktasının örneği olarak gösterdikleri, birçok usul müellifinin de bu örneğin kullanımında aynı anlayışı doğrudan veya dolaylı olarak teyit eden bir sunum yaptıkları, üstelik -Şâfiî mezhebine mensup olduğu veya en azından anılan mezhebe derin vukufunun bulunduğu kabul edilen- Teftâzânînin bile et-Telvîh adıyla yazdığı haşiyede Sardüşşerîảnın eserine birçok eleştiri yönelttiği halde bu eserdeki Şâfiî mezhebiyle ilgili bilginin yanlışlı̆̆ına değinmediği dikkate alınınca, XX. yüzyıla gelinceye kadar bilhassa Hanefî fikhını esas alan medreselerdeki fıkıh usulü öğretimi geleneği içinde bu yanlış ezberin sürmesi ve hatta pekişmesi fazla yadırganmayabilir. Zira bu bilginin fürû eserlerinden kontrol edilmesi imkânının önünde bazı engellerin bulunduğunu söylemek mümkündür. Bu bağlamda özellikle Serahsîden İbn Âbidîn’e kadar uzanan çizgide, birçok meselede Şâfiî̀nin veya Şâfiîler'in görüşlerine değinme, hatta bunları ve delillerini tartışma ihtiyacı duyan çok sayıda Hanefî fürû eseri müellifinin -ki Fethu'l-kadîr isimli mümtaz eserin sahibi muhakkik alim İbnü'l-Hümâm da bu gruptadır- bu meselede Şâfiînnin veya Şafiîler'in görüşüyle ilgilenmemeyi tercih etmiş olması önemlidir. Dolayısıyla medrese hocalarının ve öğrencilerinin -özel olarak Şâfî̀ fürû kitaplarına başvurma ihtiyacı duymadan veya bu imkânı bulamadan- fikıh usulündeki bu bilgiyi müsellemattan (herekesçe kabul görmüş önermelerden) sayarak öğrenmeye ve öğretmeye devam etmelerini izah zor olmayabilir.

Buna karşılık, fikıh ve usul yazımında ve öğretiminde mezhepler arası mukayesenin yaygınlaştığı XX ve XXI. yüzyıllarda, temel İslamî ilimler eğitimlerini medrese geleneğinin etkili olduğu ortamlarda almış olsalar da, -çoğu doktora süreçlerinden de geçerek- bir yandan akademik kurumlarda hocalık yapan diğer yandan mukayeseli fikıh ve usul yazan ve öğreten çok sayıda güzide müellifin yayınlarında bu yanlış ezberi açıkça tekrar etmeleri veya dolaylı olarak teyit eden sunumlar yapmaları şaşırtıcıdır.

$\mathrm{Bu}$ durumu açıklamak üzere farklı ihtimaller üzerinde durulabilirse de, makalenin (6.) ve (7.) nolu başlıkları altında ayrıntılarını verdiğimiz örnekler, bize, fikıh usulü yazımında ve öğretiminde, bu ilme dair eserlerde tekrar edilegelen yerleşik bilgilerin âdeta asırların imbiğinden geçmiş, güvenilirliğinde tereddüt olmayan, fürû alanındaki bilgiler ışı̆̆ında gözden geçirilmesine ihtiyaç duyulmayan veriler gibi telakki edilmesinin bu konuda önemli bir etkiye sahip olduğunu düşündürmektedir. Bu yazarlardan birçoğunun fürû-i fikıhla ilgili bir meseleyi inceledikleri yayınlarında, sadece usul eserlerine atıfta bulunmakla yetinmeleri bu düşünceyi teyit etmektedir. Öte yandan ele 
aldıkları mesele hakkında verdikleri bilgi kaynak olarak gösterdikleri yerlerde bulunmadığına göre, muhtemelen asırlardır süregelen ezberin etkisiyle, atıfta bulundukları eserlerin "istishap" ve/veya "mefkud"dan söz edilen yerlerinde bu bilgilerin mevcut olduğunu varsaymış olmalıdırlar.

Bilgi yanlışlı̆̆ını farkettiği halde usul eserlerinin otoritesine teslimiyetin etkisinden kurtulamadığı görülen Muhammed Mustafa Şelebînnin tutumu diğerlerine göre farklılık arzetmektedir. Şöyle ki: Gerek fürû gerekse usul alanlarındaki kıymetli eserlerinde eleştirel bakışı öne çıkararak yakın dönem fıkıh düşüncesinin gelişmesine önemli katkılar sağlayan yazarın, istishap ile ilgili usulî ihtilaftan kaynaklanan fürû örneklerine yer verirken mefkud hakkında yaptığı açıklama şöyledir: "Şâfiîler'e göre mefkuda başkası mirasçı olamaz, ama o ölen yakınına mirasçı olur (...); Hanefîler’e göre ise mefkuda mirasçı olunmadığı gibi o da başkasına mirasçı olamaz." ${ }^{151} \mathrm{Bu}$ anlatım fikıh usulü öğretimindeki yanlış ezberin tipik bir tekrarı niteliğinde olmakla birlikte, burada yazarın Şâfiîler'in görüşünü verdikten sonra düştügü şu dipnot ilginç görünmektedir: "Fakat muhakkik Şirbînî Cemu'l-cevâmi' haşiyesi üzerine yazdığ Takrîr'de, 'Şâfiî mezhebinde mutemet görüşe göre, yaşadığında şüphe bulunduğu için (mefkud) mirasçı olamaz; Remlî ve İbn Hacer bunu Gazzâlî̉den nakletmiştir’ demiştir (bk. II, 353).” Şayet yazar, birçok çağdaş usul yazarı gibi asırlardır tekrar edilegelen yanlışı mûtat biçimde tekrar etmekle yetinmiş olsaydı, şaşırtıcı olmayabilirdi. Fakat Şâfiî mezhebindeki görüşün gerçekte böyle olmadığı hakkında yine usul müelliflerinden ve dolaylı bir destek almaya çalışmasını izah etmek kolay değildir. Çünkü bu noktaya ilişkin farklı bir bilginin bulunduğuna dikkat çekmeye karar verince herhangi bir Şâfiî fürû eserinden bu mezhebin görüşüne muttali olabilir ve süregelen bu ezberin yanlışlığını dile getirebilirdi (Kaldı ki yazarın Hukuk Fakültesi öğrencileri için yazdığı miras hukukuyla ilgili kitap dolayısıyla konuyla özel olarak ilgilenme fırsatı bulduğu anaşılmaktadır). Asıl metinde yanlış bilgiyi verip dipnotta, "Şâfiî mezhebinde mutemet görüşe göre" şeklinde ek bilgi vermesi, okuyucunun zihninde bu mezhepte farklı görüşler bulunduğu ama "muhakkik bir alimin tespitine göre" "mutemet" görüşün ana metindekinden farklı olduğu izlenimi bırakmaktadır. Öte yandan, yazarın Şirbînînin, "Remlî ve İbn Hacer’in Gazzâlîden naklettiği şudur:" şeklindeki açıklamasında yer alan, "mûrisinin ölümünden sonra mefkudun ölümüne hükmedilirse"

151 Usûlül-fikhi'l-İslâmî, s. 344. Yazar daha sonra istishabın mutlak olarak delil değerinin bulunmadığ (gerek def'i gerekse ispatta hüccet olamayacağı) görüşüne değinmekte ve pratik sonuç itibariyle bu görüş sahiplerinin de, başkasının mefkuda mirasçı olamayacağı ve onun da -mirasçılık için gerekli olan (mûrisinin ölümü sırasında) sağ olma şartı gerçekleşmediğinden- başkasına mirasçı olamayacağı kanaatinde olduklarını belirtmektedir. 
kaydını gözden kaçırdı̆̆ görülmektedir, ${ }^{152}$ ki bu da dolaylı bilgi ile yetinmenin diğer bir sakıncasını ortaya koymaktadır.

(3) Bilgi ve görüşlerin naklinde titiz davranmanın önemi:

Fıkıh/fikıh usulü yazımında ve öğretimindeki yansımaları yukarıda geniş biçimde açılanan ve bu araştırmanın konusunu teşkil eden (Şâfiîler'e göre mefkudun mirasçı olacağı şeklindeki) yanlış ezberin, tespit edebildiğimiz kadarıyla Debûsînin İmam Şâfiî̀ye veya Şâfiî mezhebine değil bir Şafiî alimine (birden fazla da olabilir) nispet ettiği görüşün kısa süre içinde Şafiî̀ye ve Şaffîlere nispet edilir hale gelmesinden kaynaklandığı dikkate alındığında, genel olarak İslam alimlerinin bir bilginin veya görüşün aktarılmasında titiz davranılması gereği ile ilgili ilkesel tutumlarının ne kadar haklı olduğu daha iyi anlaşılmaktadır.

Hanefî mezhebine göre mefkudun ölen yakınına mirasçı olamayacağ 1 şeklinde ikinci bir yanlış ezberin oluşmasına yol açan nakillerin bu ilkesel tutumun konumuzla ilgili diğer bir istisnasını teşkil ettiği söylenebilir. Şöyle ki: Şeybânî mezhebin ilk kapsamlı fürû eseri olan el-Aslda, "mefkudun mirasçı olamayacağı" yönünde bir ifade kullanmadığı, aksine -ileriki dönemlerin fürû eserlerinin geneline yansıdığı üzere- sağ veya ölü olduğu anlaşılıncaya kadar payının koruma altına alınacağını (ve diğer vârislere her iki ihtimal dikkate alınarak yapılacak hesaba göre iki paydan daha azının verileceğini) belirttiği halde, Kudûrînnin Hanefî mezhebinin kurucu dönem fürû birikiminin özünü soyutlayıcı bir bakış açısıyla metinleştirerek sonraki doktrin çalışmaları için önemli bir temel oluşturan ve asırlar boyunca medreselerde ders kitabı olarak okutulan el-Muhtasar’ında, "Mefkud, kayıplığı sırasında vefat eden hiç kimseye mirasçı olamaz" ifadesi kullanılmış ve mefkudun payının ayrılacağından da hiç söz edilmemiştir. Daha sonra bazı müellifler burada ne kastedildiğine sşık tutucu açıklamalar yapmış olsalar da çoğunluk, "Mirasçı olamaz" önermesinden vazgeçmeme yolunu tutmuş; üstelik XIX. asırda kaleme alınan ve büyük rağbet gören, hatta Ezher'in resmî müfredatında esas alınan mezkûr eserin şerhi Meydânînin el-Lübâb’ında bu ibarenin tekrar edilmesiyle yetinilip Hanefî mezhebindeki hükme dair bir açıklama yapılmamıştır. Bu kitapları okutan hocaların Hanefî mezhebindeki doğru bilgiyi vererek bu sakıncayı bir ölçüde gidermiş olabileceği düşünülebilirse de, en güvenilir eserlerden biri olan el-Muhtasar’ı okuyanlar ve -öğrenim sırasında yapılan açıklama ne olursa olsun- hafızasına kitaptaki metni yerleştirmiş olan öğrenciler bakımından yanlış bir ezberin oluşması tabiidir. ${ }^{153}$

152 Şirbînînin açılamaları için bk. (4.) nolu başlık.

153 Bu husustaki başka bilgi ve değerlendirmeler için (3.) nolu başlığa bakılmalıdır. 
Yine, makalenin (3.) nolu başlığı altında açıklandığı üzere, Şeybânî, "mefkudun başkalarının hakları konusunda ölü sayılacağı”nı söylemediği, aksine defalarca, "Sağ mıdır ölü müdür, mirasçı mıdır değil midir bilemem" deyip, "Sağ olup olmadığının anlaşılması gerekir” fikrine vurgu yaptığı halde yaklaşık iki-üç asır sonra bazı muteber eserlerde yer alan, "Mefkud başkalarının hakları konusunda ölü hükmündedir" önermesi, -bir kısım dikkatli müellifler bundan rahatsızlık duyup bir izah getirmeye çalışsalar da- asırlar boyunca fikıh kitaplarının ilgili bölümlerinde cazip bir anlatım olarak varlığını korumuş, hatta son dönem alimlerinden Ali Haydar Efendi’nin konuya ilişkin özel risalesinde bile tekrar edilmiş ve XX-XXI. asır fıkıh usulü ders kitaplarında ve diğer bazı bilimsel yayınlarda istishabın hücciyeti ile ilgili Hanefî-Şâfiî ihtilafı bu ezber üzerinden açıklanmaya çalışılmıştır.

Diğer taraftan, mezhep içi bilgi akışıyla ilgili şartlar muvacehesinde yukarıda belirtilen Kudûrî (ö. 428/1037) etkisini açıklamak zor olmasa da, ilk dönemlerden itibaren müslüman toplumlarda ferâiz (miras hukuku) ilmine büyük önem atfedildiği, bu meyanda (matematikte de uzman olan) Secâvendînin (ö. 596/1200 [?]) es-Sirâciyye’sine (el-Ferâizüs-Sirâciyye) özellikle Hanefî̀ muhitinde büyük ilgi gösterildiği, üzerine çok sayıda şerh ve haşiye yazıldığı, hatta ezberlenmesini sağlamak için manzum hale getirildiği halde, mefkudun mirasçllığı konusunda gerek fürû gerekse usul eserlerinde buradaki bilgi hiç görülmemiş gibi bir anlatımın sürdürülmüş olması şaşırtıcıdır. Zira anılan eserde şöyle denmektedir: "Mefkud başkalarının hakları konusunda hükmü askıda olan bir kişidir (mevkūfü'l-hükm); bundan dolayı mûrisinin malından kendisine düşen pay -ceninde olduğu gibi- koruma altına alınır (...). Mefkud için pay ayrılırken izlenecek kaide şudur: Hem hayatta olduğu hem de ölü olduğu ihtimaline göre iki türlü hesap yapılır; bundan sonraki işlem cenin ile ilgili zikrettiklerimiz gibidir."154 Görüldüğü üzere burada mefkudun "ölü hükmünde olduğu"ndan ve "mirasçı olamayacağı”ndan hiç söz edilmemekte, Hanefî mezhebinde (ve diğer meşhur üç mezhepte) esas alınan hüküm açık biçimde ifade edilmektedir.

Bu tespitler, bir yandan ilmî çalışma ve yayınlarda, keza bilimsel öğretimde "asla sadık kalma"yı ve nakillerde titiz davranmayı ilmî emanet sorumluğunun bir parçası olarak görme ilkesinin ne kadar önemli olduğunu, diğer yandan da haklı bir şöhrete ve itibara sahip olmuş eserlerde hiçbir yanlış veya eksik bilgi bulunmayacağı ön kabulü ile davranmanın bu eserlere saygı anlamına gelmeyeceğini, aksine önemli yanlışlı ve eksikler görüldügünde bunların giderilmesine katkı sağlamanın onlara değer vermenin fiilî bir göstergesi sayılması gerektiğini ortaya koymaktadır. 
(4) Fıkıh usulü eserlerindeki fürû hükümlerinin "örneklendirme" amacı taşıdığına dikkat edilmesi gereği:

Fıkhî bir meselenin hükmünü tespit için usul eserlerinin ilk el kaynak olarak düşünülmemesi gerektiği, fürû hükümlerinin bu eserlerde örnek kabilinden yer aldığı, yani asıl amacın fürû hükmünün öğretilmesi değil ilgili usul kuralının açıklanması olduğu dikkatten uzak tutulmamalıdır. ${ }^{155}$ Zira özellikle mezhepler arası veya mezhep içi usulî ayrilıkların örneklendirilmesi sırasında yeterince tahkik edilmemiş veya yanlış aktarılmış bilgilere yer verilmiş olabilir. Nitekim araştırma konumuzu teşkil eden mefkudun mirasçllığı meselesinde birçok eski ve yeni usul eserinde bu durum açıkça görüldüğü gibi, -yukarıda belirtildiği üzere- örnek olarak zikrettiğimiz yazarların yanlış nakilde bulunmalarında usul eserlerine başvurmakla yetinmiş olmalarının önemli bir etken olduğu anlaşılmaktadır.

(5) Yanlış örnek kullanımının bilgi hatası olarak kalmayıp usul ihtilafının da sağlıklı yansıtılamamasına yol açması:

Hangi türü olursa olsun istishap delilinden yararlanan fakihlerin onu bir fikirler zinciri olarak sunma çabası içinde olmaları ile mefkud örneğinin usul eserlerinde takdim edilen şekliyle fıkıh mezhepleri (özellikle Hanefî ve Şâfî̀ mezhebi) arasındaki usulî görüş ayrılı̆̆ını yansıtmaya elverişli olmayan "zayıf bir halka" durumunda kalması çelişkili bir görünüm arzetmektedir. Gerçekten mefkudun ölen yakınına mirasçı olacağı ve olamayacağı şeklinde iki ayrı görüş varmış gibi bir sunum yapılması, sadece fürû ile ilgili bir bilgi hatası olmakla kalmamakta, istishap delilinin mantığı ile ilgili görüş ayrılı̆̆ının doğru yansitılmasını da engellemektedir.

(6) Fıkıh ve usul öğretiminde fikhî/hukukî analiz becerisi kazandırılmasının gerekliliği:

Fıkıh ve usul öğretiminde fikhî hüküm/kaide ve örnekler üzerinden yürünmesi ve bu konuda yeterli alt yapının oluşturulması gerekli olmakla birlikte, araştırmamız, bu bilgilerin ezberletilmesi yerine meselelerin ele alınmasında fikhî/hukukî analiz becerisi kazandırılmasının öncelikli hedef olması gereğini ortaya koymaktadır. Bunu, incelediğimiz mesele bakımından şöyle açıklamamız mümkündür: Esasen mefkudun kayıplık döneminde vefat eden yakınına mirasçı olup olamayacağı sorusunun cevaplandırılması için, bir usul ilkesinden/kaidesinden değil konunun incelendiği hukuk sistemindeki (veya fikıh mezhebindeki) mirasçllıkla ilgili teoriyi oluşturan

155 Bennânînin, incelediğimiz meseleye ilişkin açılamaları takiben kullandığı bu yöndeki bir ifade için bk. Hâşiye, II, 349. 
"mirasçılık sebepleri", "mirasçı olmanın şartları", "miras engelleri" gibi ana başlıklardan yola çıkılmasının daha uygun olacağı açıktır. Üstelik bazı fürû-i fikıh ve furûk eserlerinde bu konudaki yaklaşımların eleștirel biçimde ele alındığı, kavram inceliklerine inen tartışmalar ışığında titiz bir incelemeye tâbi tutulduğu görülmektedir. Mesela Karâfî furûkla ilgili ünlü eserinde, ferâiz yazarlarının bu konuda "şartlar" başlığını ihmal etmelerini ele almakta, esere şerh ve haşiye yazan müellifler de bu hususu tartışmaktadır. ${ }^{156}$

Miras hukukunun belirtilen ana başlıklarıyla ilgili bazı hususlarda fıkıh mezhepleri arasında görüş ayrılıkları bulunsa da, araştırma konumuzu ilgilendiren mesele bakımından önemli bir ihtilafın bulunmadığ 1 görülmektedir. Şöyle ki: Bu meselede "mirasçlık sebepleri” özel bir önemi haiz bulunmamaktadır; zira zaten bu sebeplerden birinin var olduğu, bir başka anlatımla -sağ olduğu bilinseydi- "mirasçı" sıfatı taşıyacağında görüş ayrıllğı bulunmayan bir kişinin durumu ele alınmaktadır. Şu halde "mirasçı olmanın şartları"ndan biri yoksa veya "miras engelleri”nden biri varsa bu kişinin (mefkudun) mirasçı olamayacağ 1 söylenebilecek, aksi halde söylenemeyecektir.

Mûrisin vefatı sırasında vârisin sağ olma şartı üzerinde ittifak bulunduğuna göre mefkudun mirasçı olabilmesi için bu şartın varlığının mercek altına alınması gerekecektir. Nitekim gerek Hanefîler gerekse Şâfiîler bu yolu tutmuşlar ve o esnada mefkudun "sağ" veya "ölü” olduğunun bilinmediğini esas alarak, -yaşadığının kesin olarak bilinmesi durumunda hak kaybına uğramaması için- payının (onun bakımından lehte olan ihtimale göre) koruma altına alınmasına hükmetmişlerdir. Bazı müellifler mefkudun durumunu "miras engelleri" ana başlı̆̆ının bir uzantısı gibi ele almış olsalar da, sonuç itibariyle mirasçılık sıfatının ortadan kalkmadığını ve sağ olarak ortaya çıkması durumunda miras payını alacağını kabul ettiklerinden, burada gerçek bir miras engelinin söz konusu olmayıp mefkuda ayrılacak payın fiilen onun mülkiyetine geçmeyeceğinin kastedildiğine dair açıklamalar yapma cihetine gitmişlerdir. ${ }^{157}$ Özellikle bazı Şâfiî müellifleri, bu konuyu "şu an itibariyle/ bulunulan durumda fiilen tasarrufta bulunmayı engelleyen sebepler" ("mâ

156 Karâfî, el-Furûk, IV, 198-202; İbnü’ş-Şât, İdrârü̧ş-şurûk, IV, 198-202; Ali b. Hüseyin, Tehzîbül-furûk, IV, 216-17.

157 Mesela İbnü’l-Hâcib, bu konuyu "Miras Engelleri” ana başlığının, “varlığında veya cinsiyetinde şüphe edildiği için haklarında 'hemen' (âcilen) işlem yapılmayacaklar" alt başlığında ele almakta (el-Muhtasar, XVII, 511); şârih Hevvârî, müellifin ibaresinin hiçbir işlem yapılmayacağı şeklinde anlaşılmaması için "hemen” (âcilen) kaydını koymak suretiyle bu ibareyle "varlığında şüphe bulunan kişinin yaşayıp yaşamadığı belli oluncaya kadar işlem" (ilgililere teslimin) yapılmayacağını kastettiğini belirtmektedir (Şerhu Câmiu'l-ümmehât, XVII, 511). 
yemna 'u mine's-sarfi fîll-hâl') vb. başlıklar altında incelemeyi tercih etmişlerdir. Gazzâlî bu alt başlığı kullanmakla birlikte ana başlı̆̆ın "miras engelleri” olmasına binaen ${ }^{158}$ Râfiî şu önemli açıklamayı yapma ihtiyacı duymuştur: "Öncelikle belirtelim ki, bunun manilerden ("mine'l-mevâni' evi'd-devâfi") sayılması yerinde değildir. Zira -görüleceği üzere- derhal tasarrufta bulunmaktan kaçınmak, hak edişle ilgili şüphe ortadan kalkıncaya kadar beklemekten (payı koruma altına almaktan) başka bir şey değildir. Bu durumda onun hak sahibi olmadığı anlaşılırsa ona göre uygulama yapılır, aksi takdirde (hak sahibi olduğu anlaşllırsa) kendisinin tasarrufuna verilir." ${ }^{159}$

(7) Fıkıh düşüncesinin gelişmesinde kavramların inceltilmesinin önemi:

Genelde İslam alimlerinin, özelde fakihlerin "tanım" konusuna erken dönemlerden itibaren önem verdikleri ve değişik disiplinlerle ilgili "hudûd" (tanımlar) kitapları ve risaleleri kaleme aldıkları bilinmektedir. Mesela Karâfînin furûkla ilgili ünlü eserinde yukarıda değinilen konu vesilesiyle, bir işin hakikati (mahiyeti) hususunda ihtilafa düşülmesi durumunda "tanımlar"ın (el-hudûd) hakem kılınması gerektiğini belirten bir söze dikkat çekmesi ${ }^{160}$ de bu anlayışı yansıtma açısından önemlidir.

Fakihlerin mefkudun mirasçılığını ele alırken onun için pay ayırma/ onun payını koruma altına alma hükmünü "vkf" kökünden türetilen kelimelerle ("vakf", "tevkif", "yûkaf", "tevakkuf", "mevkuf" vb.) ifade etmeleri de fıkıh terminolojisinin geliştirilmesi bakımından önemli bir adım sayılır. $\mathrm{Bu}$ kelimelerle muhataplar bir hakkın askıya alınması/ayrılması/tutulması anlamının kastedildiğini bildikleri için ilk dönemlerde bu kavramın kapsamını belirleme ihtiyacının fazlaca duyulmaması tabii karşılanabilir. Ancak pay ayırmanın hukukî mahiyeti ve ayrılan paya uygulanacak hükümlere ilişkin meselelerin gündeme gelmesiyle birlikte bazı müelliflerin bu hususta bazı kavram inceliklerine dikkat çekme ihtiyacı duydukları görülmektedir.

Yukarıda belirtildiği üzere Secâvendînin, "Mefkud başkalarının hakları konusunda hükmü askıda olan bir kişidir (mevkūfü’l-hükm)" şeklindeki nitelemesi; Râfiînnin miras teorisinin ana hatlarını netleştirme bağlamında, “Tevakkuf mirasçı olmadığına hükmetmek demek değildir" ("ve't-tevakkuf leyse hükmen bi ademi't-tevrîs") ${ }^{161}$ şeklindeki açıklaması; yine İbn Kudâme’nin, "Vakf (askıya alma) kesin biçimde hacb (engelleme) anlamına

\footnotetext{
158 el-Vecîz, s. 249-50.

159 el-Azîz, XI, 220 (Râfiînnin konu başında ve dördüncü engeli şerhederken de benzeri ikazlarda bulunduğu görülmektedir [bk. XI, 176-77, 209]).

160 el-Furûk, IV, 199.

161 el-Azîz, XI, 220.
} 
gelmez; bu, malın şüpheli olduğu kabul edilen iki cihetten birine 'sarf'edilmesinden alıkonması (tevakkuf) demektir" ifadesi ${ }^{162}$ bu durumun örnekleri arasında zikredilebilir.

Birçok Hanefî müellifinin son tahlilde mefkudun sağmış gibi düşünülerek kendisinin lehine olan payın ayrılacağını ("vakf”) belirtmesine mukabil, başlangıçta konuyu vazederken onun başkalarının hakları bakımından "ölü sayıldığını" ve "mirasçı olamayacağını" söyleyip mirasçı sayılmasının sakıncalarından söz etme ihtiyacı duymasının, pay ayırma/hakkı askıya alma (vakf) hükmünün/işleminin hukukî mahiyetinin belirsiz kalmasıyla da ilintili olduğu gözlenmektedir.

Bunun tedbir amaçlı bir işlem/hüküm olduğunun kabulü halinde, bu aşamada mefkudun fiilen mirasçı sayılmamakla birlikte sağ olarak dönmesi şartına bağlı olarak mirasçılık sıfatının askıya alındığı söylenebilecektir, ki anılan iki mezhep (hatta dört mezhep) bu noktada müttefiktir.

(8) Anlatım kolaylığının cazibesine kapılmanın sakıncaları:

Fıkıh ve usul literatüründe eleştirel bakışı yansıtan yaklaşım ve tartışmalara sıkça rastlanmakla birlikte, mefkud örneğinde böyle bir bakışın esas alınmayıp mevcudu aynen aktarma yolunun tutulmasında, "Def'ide hüccettir ama ispatta hüccet değildir” kuralının kolay anlatılması/anlaşılması ve akılda kalması gibi bir çekiciliğin etkili olduğu düşünülebilir. Yine mefkudun, kendisi (mevcut hakları) bakımından "sağ", başkalarının hakları bakımından "ölü" sayıldığının ifade edilmesi de bu açıdan anlaşılır bir tutum sayılabilir. ${ }^{163}$ Fakat bu meselenin hükmünün, "Mirasçı olur" ve "Mirasçı olamaz" şeklinde sunumu fikhî hükmün hakikatini yansıtan bir anlatım değildir. Çünkü bu kaziyelerin hukukî sonuçları bellidir ve mefkud için bu sonuçlar geçerli değildir. Dolayısıyla bir taraftan anlatım kolaylı̆̆ı için başka uygun örneğin ikame edilmesi, diğer taraftan da bu meselenin izahı için önceki maddede değinilen hakkın askıya alınması, payın koruma altına alınması ("vakf") kavramından, fikıh eserlerinde yer alan "gerçek ölüm" ve "takdirî ölüm” gibi ayırım ve kavramlaştırmalardan yararlanılması daha isabetli olur.

162 el-Muğnî, IX, 190.

163 Nitekim bazı yazarların, "Bu ihtilafın en açık örneği mefkuddur" gibi ifadelerinden, örneğin kolay anlaşılması ve akılda kalması özelliğini öne çıkardıkları anlaşılmaktadır (mesela bk. Muhammed Ebû Zehre, Usûlül-fikh, s. 279). Bugā da bu meselenin istishabın hem def'ide hem ispatta mı sadece def'ide mi hüccet olduğu ile ilgili ihtilafın sonucunun açık biçimde ortaya çıktığı en meşhur meselelerden olduğunu söylemektedir (Eserüll-edilletil-muhtelef fîhâ, s. 223). 


\section{Sonuç}

Araştırmamız, birçok Hanefî fıkıh usulü eseri ile yakın dönem fikıh usulü ders kitabında ve konuya ilişkin yayında yer alan, "Mefkud, Hanefî mezhebine göre, kayıplık döneminde vefat eden yakınına mirasçı olamaz, Şâfiî mezhebine göre ise mirasçı olur" şeklindeki bilginin ve "bu hüküm farklılığının, birinci mezhepte istishâbü'l-hâlin sadece def'ide hüccet sayllırken ikincisinde hem def 'ide hem ispatta hüccet sayılmasından kaynaklandığı" yönündeki açıklamanın doğru olmadığını göstermektedir. Zira mefkudun, kayıplık döneminde vefat eden yakınına mirasçı olup olamayacağı sorusunun gerek Hanefî mezhebinin gerekse Şâfiî mezhebinin fürû-i fikıh eserlerinde aynı yönde cevaplandırıldığı, yani hayatta olup olmadığı bilinemediği için mefkudun payının koruma altına alınıp durumu belli oluncaya kadar bekletileceği açıkça ifade edilmektedir. Bu sebeple bir yandan "mefkudun mirasçı olamayacağı"nın diğer yandan da "mefkuda ait miras payının ayrılacağı"nın ifade edilmesi arasında bir uyumsuzluk bulunduğunu önemseyen bazı Hanefî müelliflerinin, "mirasçı olamama" ile miras payına mâlik olamayacağının ve fiilen ilgililere (mefkudun kayyımına) teslim edilmeyeceğinin kastedildiği yönünde bir açılama yapma ihtiyacı duydukları görülmektedir.

Esasen mevcut verilere göre, mefkud için "Mirasçı olamaz" ve "Mirasçı olur" şeklindeki önermeler sadece bu iki mezhebe göre değil fakihlerin büyük çoğunluğuna göre doğru değildir. Zira "Mirasçı olamaz" önermesi onun dikkate alınmadan ölen yakınına ait terekenin diğer vârisler arasında taksim edileceği, "Mirasçı olur" önermesi ise söz konusu terekenin mefkudun sağ olduğu varsayılarak taksim edileceği sonucunu düşündürür. Oysa fakihlerin büyük çoğunluğuna göre bu meselede -hayatta olup olmadığı bilinmediği için- mefkudun mirasçı olacağına veya olamayacağına hükmedilmez; durumu açıklı̆g kavuşuncaya kadar payı ayrılır ve o pay üzerindeki hakkı koruma altına alınır. Hatta mefkudun çıkıp gelmesi, yani mirasçı olması ihtimali daha baskın görüldüğü ve İslam miras hukukunda yakın mirasçının uzak mirasçıyı engellemesi (hacb) kuralı bulunduğu için, miras o esnada, "Mefkudun sağ olduğu bilinseydi nasıl paylaştırılırdı?" ve "Mefkudun ölü olduğu bilinseydi nasıl paylaştırılırdı?” sorularından hareketle iki türlü hesaplama yapılmakta, ihtiyaten diğer mirasçılar için aleyhte olan pay kendilerine verilip mefkudun payı buna göre ayrılmaktadır. Dolayısıyla, özellikle Hanefî fürû eserlerinde yaygın biçimde yer alan, "Mefkud kendi hakları konusunda sağ, başkalarının hakları konusunda ölü hükmündedir” şeklindeki kalıp ifadenin ikinci önermesini makul bir açıklamaya kavuşturmak mümkün görünmemektedir. Zira "ölü” sayılması, mefkudun mirasçı olamayacağına ve mûrisine ait terekenin mefkudun mirasçılar arasında bulunmadığı varsayımına göre 
taksim edilmesine hükmetme anlamına gelir, ki bu Hanefî mezhebindeki ortak kabulün pratik sonucu ile bağdaşmaz.

Hanefîler'e göre "istishâbü'l-hâl"in sadece def'ide hüccet sayılırken Şâfî̀ler'e göre hem def'ide hem ispatta hüccet sayıldığg şeklinde özetlenen usul ihtilafının bu örneğe dayalı izahının fikıh usulü yazımı ve öğretimi ile meşgul olanlar tarafından tekrar edilegelmesi sebebiyle, belirtilen meselede iki mezhepte iki farklı uygulama yapıldığı, yani bu durumda Hanefî mezhebine göre mefkudun mirasçı olamadığı, Şâfiî mezhebinde ise mirasçı olduğu bilgisi zihinlerde yerleşmeye devam etmektedir. Bu bilginin doğru olmadığı hakkında birkaç yayında kısa notlar bulunsa da, on yıllardır İslam dünyasında yaygın biçimde okutulagelen ve yeni baskıları yapılan pek çok ders kitabında bu yanlışlı̆ın süregelmesi yanında; fikıh ve usul alanında kıymetli yayınları bulunan bazı akademisyenlerin konuyu özel olarak inceledikleri çalışmalarda bile, fikıh usulü eserlerinde tekrar edilegelen yerleşik bilgileri âdeta asırların imbiğinden geçmiş, güvenilirliğinde tereddüt edilemeyecek veriler gibi kabul edip fürû kaynaklarını ihmal ettikleri ve böylece yanlış bir ezberin daha da perçinlenmesine katkı sağladıkları görülmektedir. Makalenin (7.) nolu başlığ 1 altında bu tür yayınların bazı örnekleri eleştirel bir bakışla incelenmiştir.

Sonuç olarak, istishap delili işlenirken, mefkud örneğinden, kaybolduğu sırada yaşadığ 1 kesin olarak bilinmesine binaen, sadece ona ait olduğu bilinen haklar konusunda yararlanılması ve -öldüğüne dair delil bulunmadıkçasağlara ait hükümlerin uygulanacağının belirtilmesi uygun olur. Kayıplığ 1 esnasında kendisinin de mirasçıları arasında bulunduğu bir yakının vefat etmesi durumunda ise, bu delilin işletilmesiyle ilgili farklılığa binaen "mirasçı olacağı" veya "mirasçı olamayacağı" şeklinde farklı sonuçlara ulaşıldığından söz edilmemesi gerekir.

Böyle bir araştırmanın "Acaba Şâfiî mezhebine ait eserlerde böyle bir bilgi yer almadığı halde, Şâfî̀ye veya Şâfiîler'e göre mefkudun -kayıplık döneminde vefat eden- yakınına mirasçı olacağı bilgisi nereden kaynaklanmıştır?” sorusuna ilgisiz kalması elbette düşünülemez. Makalenin (2.1.) ve (8.) nolu başlıkları altında bu soruya cevap teşkil edebilecek açıklamalara yer verilmiştir.

Son olarak, makalenin (8.) nolu başlığı altında, mefkud örneğine ilişkin tespitler ışığında, fikıh/fikıh usulü yazımında ve öğretiminde karşılaşılan bazı metot sorunlarıyla bunların hukuk tefekkürünün gelişimi üzerindeki olumsuz etkilerine dikkat çekilmeye çalışılmıştır.

Bu çalışma bize, sağlıklı bilgiye erişmenin en güvenli yolunun ilim ağacının meyvelerini dalından bizzat koparma olduğunu belirten metaforun haklılı̆̆ını bir defa daha göstermiştir. 


\section{Bibliyografya}

Abdülazîz el-Buhârî, Keşfü̉l-esrâr an usûli Fahri'l-İslâm el-Bezdevî̀, nşr. M. el-Mu'tasım-Billâh el-Bağdâdî, I-IV, Beyrut: Dârü'l-kitâbi'l-Arabî, 1417/1997.

Abdülvehhâb Hallâf, İlmü usûlil-fikh ve hulâsatü târîhit-teşrî̀l-İslâmî, Kahire 1369/1950.

Abdülvehhâb Hallâf, Mesâdirü̉t-teşrî̀'l-İslâmî fìmâ lâ nassa fîh, Küveyt 1392/1972.

Ali b. Hüseyin, Muhammed, Tehzîbül-furûk ve'l-kavâidü's-seniyye fi'l-esrâril-fikhiyye, Şehâbeddin el-Karâfî, el-Furûk: Envârüll-burûk fî envâi'l-furûk içinde, I-IV, Beyrut: Dârü'l-ma'rife, t.y.

Ali Haydar Efendi, Küçük, Risâle-i Mefkūd, İstanbul: Matbaa-i Ebüzziya, 1309.

Âmidî, Seyfeddin, el-İhkâm fî usûli’l-ahkâm, I-IV, Kahire: Müessesetü’l-Halebî, 1387/1967.

Attâr, Hasan b. Muhammed, Hâşiyetü'l-Attâr alâ Cem 'i'l-cevâmi', I-II, Kahire: el-Mektebetü’t-ticâriyyetü'l-kübrâ, 1358 .

Aybakan, Bilal, “Şâfiî Mezhebi”, DİA, 2010, XXXVIII, 233-247.

Aybakan, Bilal, "el-Vecîz", DİA, 2012, XLII, 587-588.

Bâbertî, et-Takrîr li-usûli Fahril-İslâm el-Bezdevî, nşr. Abdüsselâm Subhî Hamed, I-VI, Küveyt: Vizâretü'l-evkāf ve'ş-şuûni'l-İslâmiyye, 1426/2005.

Bahrülulûm el-Leknevî, Fevâtihu'r-rahamût bi-şerhi Müsellemi’s-sübût fî usûli'l-fikh, Gazzâlî, el-Mustasfâ içinde, I-II, Bulak: el-Matbaatü'l-emîriyye, 1324.

Bardakoğlu, Ali, “İstishâb”, DİA, 2001, XXIII, 376-381.

Bedrân, Ebü'l-Ayneyn Bedrân, Usûlül-fikhi'l-İ́lâmî, İskenderiye: Müessesetü şebâbi'l-câmia, 1984.

Bennânî, Abdurrahman b. Câdullah, Hâşiyetü'l-Allâme alâ şerhi'l-Celâl el-Mahallî alâ metni Cem'i'l-cevâmi', I-II, Kahire: Mabaatü dâri ihyâi'l-kütübi'l-Arabiyye, t.y.

Bihârî, Müsellemü’s-sübût, Gazzâlî, el-Mustasfâ min ilmi'l-usûl içinde, I-II, Bulak: el-Matbaatü'l-emîriyye, 1324 .

Bilmen, Ömer Nasuhi, Hukukı İslâmiyye ve Istılahatı Fıkhiyye Kamusu, I-VII, İstanbul: Bilmen Yayınevi, 1970.

Birmâvî, İbrâhim b. Muhammed, Hâşiyetü'l-Birmâvî alâ şerhỉr-Rahbiyye li'l-Mardinî, nşr. Sa'd Abdullah Muhammed - Muhammed Ra'd Abdullah el-Bâlânî, Amman: Dârü’n-nûr, 2018.

Bugā, Mustafâ Dîb, Eserü'l-edilleti'l-muhtelef fîhâ (mesâdirü't-teşrîi't-teberyye) fi'l-fikhi'l-İslâmî, Dımaşk: Dârü'l-İmâm el-Buhârî, t.y.

Bugā, Mustafâ Dîb, Usûlüll-fikhi'l-İslâmî: Dirâse âmme, Dımaşk: Dârü'l-Mustafâ, 1425/2004.

Büceyrimî, Süleyman b. Muhammed b. Ömer, Hâşiyetü’l-Büceyrimî, nşr. Abdullah Mahmûd M. Ömer, I-III, Beyrut: Dârü'l-kütübi'l-ilmiyye, 1420/2000.

Buhûtî, Keşşâfül-kınâ‘ an metni'l-İknâ', nşr. İbrâhim Ahmed Abdülhamîd, I-VII, Riyad: Dâru âlemi'l-kütüb, 1423/2003.

Büveytî, el-Muhtasar, nşr. Ali Muhyiddin el-Karadâğîi, Beyrut: Dârü’l-minhâc, 1436/2015.

Cîven, Şerhu Nûri'l-envâr, Ebü'l-Berekât en-Nesefî, Keş̧ü̉l-esrâr içinde, I-II, Beyrut: Dârül-kütübi'l-ilmiyye, 1406/1986. 
Cürcânî, Seyyid Şerîf, Şerhu’l-Ferâizi’s-Sirâciyye, İstanbul: Dârü't-tıbâati'l-âmire, 1309.

Cüveynî, İmâmü'l-Haremeyn, el-Burhân fî usûli'l-fikh, nşr. Abdülazîm ed-Dîb, I-II, Devha: Metâbiu'd-Devha el-hadîse, 1399.

De Bellefonds, Y. Linant, “Istishāb”, Encyclopédie de l'Islam, nouvelle édition, Leiden: Brill, 1978, IV, 281-282.

De Bellefonds, Y. Linant, "Istishāb", The Encyclopaedia of Islam, new edition, Leiden: Brill, 1978, IV, 269.

Debûsî, el-Esrâr, nşr. Salim Özer, Debbusinin "el-Esrâr fi'l-Usul ve'l-Furû" Adlı Eserinin Tahkik ve Tahlili içinde, II (doktora tezi), Erciyes Üniversitesi, Kayseri, 1997.

Debûsî, Takvîmü'l-edille fî usûli’-fikh, nşr. Halîl Muhyiddin el-Meys, Beyrut: Dârü'l-kütübi'l-ilmiyye, 1421/ 2001.

Debûsî, Takvîmüll-edille, Süleymaniye Ktp., Laleli, nr. 690.

Düreynî, M. Fethî, Buhûs mukārene fi'l-fikhil-İslâmî ve usûlih, I-II, Beyrut: Müessesetü’r-risâle, 1414/1994.

Emîr Pâdişâh, Teysîrüt-tahrîr, I-IV, Kahire: Matbaatü Mustafa el-Bâbî el-Halebî, 1350-51.

Ençakar, Orhan, "Hanefî Fıkıh Literatüründe Gelenek Oluşturan Kayıp Bir Metin: Muhtasarü'l-Kerhî", İslâm Araştırmaları Dergisi, 37 (2017): 7-32.

Ençakar, Orhan, Kerhînin Muhtasarının Hanefî Muhtasar Geleneğine Etkisi -Kudûrînin Muhtasarının "İcâre" Bölümü Çerçevesinde- (yüksek lisans tezi), Marmara Üniversitesi, İstanbul, 2013.

Fahreddin er-Râzî, el-Mahsûl, nşr. M. Abdülkādir Atâ, I-II, Beyrut: Dârü'l-kütübỉl-ilmiyye, $1420 / 1999$.

Gazzâlî, el-Vecîz, nşr. Ahmed Ferîd el-Mezîdî, Beyrut: Dârü'l-kütübi'l-ilmiyye, 1437/2016.

Gazzâlî, el-Mustasfâ min ilmiłl-usûl, I-II, Bulak: el-Matbaatü’l-emîriyye, 1322-24.

Güney, Necmeddin, Kudûrînin Şerhu Muhtasaril-Kerhî Adlı Eserinin "Siyer" Bölümünün Edisyon Kritiği (yüksek lisans tezi), Selçuk Üniversitesi, Konya, 2006.

Habbâzî, el-Muğnî fî usûli'l-fikh, nşr. M. Mazhar Bekā, Mekke: Câmiatü Ümmi'l-kurâ, 1403/1983.

Haddâd, Ebû Bekir, el-Cevheretü’n-neyyire, nşr. Sâid Bekdâş, I-IV, Amman: Ervika li'ddirâsât ve’n-neșr, 1436/2015.

Halebî, İbrâhim b. Muhammed, Mülteka'l-ebhur, Şeyhîzâde [Dâmâd], Mecmau'l-enhur içinde, nşr. Muhammed Hasan Talu v.dğr., I-II, İstanbul: Tereke Yayınc1lık,1436/2015.

Halîl b. İshak el-Cündî, el-Muhtasar, Hattâb, Mevâhibü'l-celîl içinde, nşr. Zekeriyyâ Umeyrât, I-VIII, Beyrut: Dârü'l-kütübi'l-ilmiyye, 1428/2007.

Haral Yalçı, Nurhayat, İlk Beş Asır Usulü’l-Fıkh Literatüründe İstıshab Delili (doktora tezi), Marmara Üniversitesi, İstanbul, 2008.

Hasan, Ali Seyyid, el-Ahkâmü̉l-hâssa bi'l-mefkūd: Dirâse mukārene beyneşşserîati'l-İslâmiyye ve'l-kānûneyni'l-Misrî ve'l-Fransî, Kahire: Dârü’n-nehdati'l-Misriyye, 1984.

Hasebullah, Ali, Usûlü't-teşrî̀'l-İslâmî, Kahire: Metâbiu'l-mektebi'l-Misrî el-hadîs, $1402 / 1982$. 
Haskefî, ed-Dürrüll-muhtâr, İbn Âbidîn, Reddül-muhtâr, nşr. Hüsâmeddin b. M. Sâlih elFerfûr, I-XVI, Dımaşk: Dârü's-sekāfe ve’t-türâs, 1421/2000.

Hudarî, Usûlüll-fikh, Kahire: el-Mektebetü’t-ticâriyyetü'l-kübrâ, 1389/1969.

İbn Abdüsselâm el-Hevvârî, Şerhu Câmii'l-ümmehât, nşr. Ahmed b. Abdülkerîm Necîb, I-XVII, Beyrut: Dârü’n-nevâdir, 1439/2017.

İbn Âbidîn, Reddül-muhtâr, nşr. Hüsâmeddin b. M. Sâlih el-Ferfûr, I-XVI, Dımaşk: Dârü's-sekāfe ve’t-türâs, 1421/2000.

İbn Berhân, el-Vüsûl ile'l-usûl, nşr. Abdülhamîd Ali Ebû Züneyd, I-II, Riyad, 14031404/1983-84.

İbn Emîru Hâc, et-Takrîr ve't-tahbîr, I-III, Bulak: el-Matbaatül-kübrâ el-emîriyye, 1316.

İbn Hacer el-Heytemî, Tuhfetü'l-muhtâc bi-şerhi'l-Minhâc, nşr. Enver b. Ebû Bekir ed-Dağıstânî, I-X, Beyrut: Dârü'z-ziyâ, 1441/2020.

İbn Kudâme, Ebü'l-Ferec, eş-Şerhu'l-kebîr, Muvaffakuddin İbn Kudâme, el-Muğnî içinde, I-XIV, Beyrut: Dârü'l-kitâbi'l-Arabî, 1392-93/1972-73.

İbn Kudâme, Muvaffakuddin, el-Kâfî̀, nşr. Abdullah b. Abdülmuhsin et-Türkî, I-VI, Cîze: Hecer li't-tıbâa ve’n-neşr ve’t-tevzî́, 1417-18/1997.

İbn Kudâme, Muvaffakuddin, el-Muğnî, nşr. Abdullah b. Abdülmuhsin et-Türkî - Abdülfettâh Muhammed el-Hulv, I-XV, Riyad: Dâru âlemil'-kitâb, 1419/1999.

İbn Melek, Şerhu'l-Menâr, nşr. İbrâhim Rüşdî, İstanbul: Dârü’t-tıbâati'l-âmire, 1292.

İbn Nüceym, Sirâceddin, en-Nehrül-fâik, nşr. Ahmed İzzû İnâye, I-III, Beyrut: Dârü'l-kütübi'l-ilmiyye, 1422/2002.

İbn Nüceym, Zeynüddin b. İbrâhim, el-İstishâb (er-Risâletüll-hâmise ve's-selâsûn), Resâilü İbn Nüceym içinde, nşr. Halîl el-Meys, Beyrut: Dârü'l-kütübi'l-ilmiyye,1400/1980, s. 265-274.

İbn Nüceym, Zeynüddin b. İbrâhim, el-İstishâb (er-Risâletü̉l-hâmise ve's-selâsûn), er-Resâilü̈z-Zeyniyye içinde, Süleymaniye Ktp., Laleli, nr. 3694.

İbn Nüceym, Zeynüddin b. İbrâhim, el-İstishâb (er-Risâletü'l-hâmise ve's-selâsûn), Resâilü İbn Nüceym içinde, Kayseri Râşid Efendi Ktp., nr. 198.

İbn Nüceym, Zeynüddin b. İbrâhim, el-Bahrür-râik, I-IX, Beyrut: Dârü'l-ma'rife, t.y.

İbn Nüceym, Zeynüddin b. İbrâhim, el-Eşbâh ve’n-nezâir, nşr. M. Mutî́ el-Hâfız, Dımaşk: Dârü'l-fikr, 1403/1983.

İbn Nüceym, Zeynüddin b. İbrâhim, Fethu'l-gaffâr bi-şerhi'l-Menâr: Mişkâtü'l-envâr fî usĥlì-menâr, I-III, Kahire, 1355/1936.

İbn Nüceym, Zeynüddin b. İbrâhim, Lübbü̉l-usûl, nşr. M. Fâl es-Seyyid eş-Şenkītî, İstanbul: TDV İSAM Yayınları, 1441/2020.

İbn Şâs, İkdü'l-cevâhiris-semîne fî mezhebi âlimi'l-Medîne, nşr. M. Ebü’l-Ecfân - Abdülhafîz Mansûr, I-III, Beyrut: Dârü’l-garbi'l-İslâmî, 1415/1995.

İbnü'l-Hâcib, el-Muhtasar, İbn Abdüsselâm el-Hevvârî, Şerhu Câmii’l-ümmehât içinde, nşr. Ahmed b. Abdülkerîm Necîb, I-XVIII, Beyrut: Dârü’n-nevâdir, 1439/2017.

İbnü'l-Hümâm, et-Tahrîr, İbn Emîru Hâc, et-Takrîr ve't-tahbîr içinde, I-III, Bulak: el-Matbaatüll-kübrâ el-emîriyye, 1316 . 
İbnü'l-Hümâm, Fethu’l-kadîr, I-VII, Beyrut: Dâru ihyâi't-türâsi'l-Arabî, t.y.

İbnü'l-Kās, Ebü'l-Abbas Ahmed, et-Telhîs, nşr. Ali M. Muavvaz - Âdil Ahmed Abdülmevcûd, Mekke: Mektebetü Nizâr Mustafa el-Bâz, 1421/2000.

İbnü's-Sââtî, Muzafferüddin, Mecmau'l-bahreyn, nşr. İlyas Kaplan, Beyrut: Dârü'l-kütübi'l-ilmiyye, 2005/1426.

İbnüş-Şât, İdrârüşs-şürûk alâ envâil-furûk, Şehâbeddin el-Karâfî, el-Furûk içinde, I-IV, Beyrut: Dârü'l-ma'rife, t.y.

İsnevî, Nihâyetüs-sûl fî şerhi Minhâcill-usûl, I-IV, Beyrut: Âlemü'l-kütüb, t.y.

"el-İstishâb”, Mevsûatü Cemâl Abdinnâsır fi'l-fikhi'l-İslâmî, 1391, VII, 61-68.

İzmîrî, Mevlânâ Mehmed, Hâsiye alâ Mirâti’l-usûl, I-II, İstanbul: Matbaa-i Âmire, 1309.

Juynboll, Th. W., “İstishâb”, İA: İslâm Ansiklopedisi, 1987, V/2, s. 1221.

Karâfî̀, Şehâbeddin, el-Furûk: Envârüll-burûk fî envâi'l-furûk, I-IV, Beyrut: Dârü’l-ma'rife, t.y.

Karâfî, Şehâbeddin, ez-Zehîre, nşr. Muhammed Haccî, I-XIV, Tunus: Dârül-garbi'l-İslâmî, 2012.

Kâsânî, Bedâiu's-sanâi', I-VII, Kahire: el-Matbaatü'l-Cemâliyyetü'l-âmire, 1327-28.

Kirmastî, Zübdetü’l-vüsûl ilâ umdetill-usûl, nşr. Abdurrahman Haçkalı, Beyrut: Dâru Sâdır, $1428 / 2008$.

Kudûrî, el-Mevsûatül-fikhiyyetül-mukārene: et-Tecrîd, nşr. M. Ahmed Sirâc - Ali Cumáa Muhammed, I-XII, Kahire: Dârü's-selâm, 1425/2004.

Kudûrî, el-Muhtasar, Abdülganî b. Tâlib el-Meydânî, el-Lübâb fî şerhi'l-Kitâb içinde, nşr. M. Muhyiddin Abdülhamîd, I-IV, Kahire: Matbaatü'l-Medenî, 1381-83/1961-63.

Kurlânî, Celâleddin, el-Kifâye, İbnü'l-Hümâm, Fethu'l-kadîr içinde, I-VII, Beyrut: Dâru ihyâi't-türâsi'l-Arabî, t.y.

Lahmî, Ebü’l-Hasan Ali b. Muhammed, et-Tebsıra, nșr. Ahmed Abdülkerîm Necîb, I-XIII, Beyrut: Dâru İbn Hazm, 1433/2012.

Lâmişî, Kitâb fî̀ Usûli’l-fikh, nşr. Abdülmecîd et-Türkî, Beyrut: Dârü'l-garbi'l-İslâmî, 1995.

Leknevî, M. Abdülhalîm, Kamerü'l-akmâr li-Nûri'l-envâr fî şerhi'l-Menâr, nşr. M. Abdüsselâm Şâhin, I-II, Beyrut: Dârü'l-kütübi'l-ilmiyye, 1415/1995.

Mahallî, Şerhu'l-Celâl el-Mahallî alâ Cem'ỉl-cevâmi li'l-imâm İbni’s-Sübkî, Hasan b. Muhammed el-Attâr, Hâşiyetü’l-Attâr alâ Cem‘il-cevâmi' içinde, I-II, Kahire: el-Mektebetü’t-ticâriyyetü’l-kübrâ, 1358.

Mâverdî, el-Hâvi'l-kebîr, nşr. Ali M. Muavvaz - Âdil Ahmed Abdülmevcûd, I-XIX, Beyrut: Dârü'l-kütübi'l-ilmiyye, 1419/2009.

Mecelle-i Ahkâm-ı Adliyye.

Mehâmilî, el-Lübâb fill-fikhişs-Şâfiî, nşr. Abdülkerîm b. Suneytân el-Amrî, Medine: Dârü’l-Buhârî, 1416.

Mergīnânî, Burhâneddin, el-Hidâye, İbnü’l-Hümâm, Fethu'l-kadîr içinde, I-VII, Beyrut: Dâru ihyâi't-türâsi'l-Arabî, t.y.

Mevsılî, Abdullah b. Mahmûd, el-Muhtâr, nşr. Mahmûd Ebû Dakīka, I-V, Kahire: y.y., $1370 / 1951$. 
Mevsılî, Abdullah b. Mahmûd, el-İhtiyâr li-ta'lîli'l-Muhtâr, nşr. Mahmûd Ebû Dakīka, I-V, Kahire: y.y., 1370/ 1951.

Meydânî, Abdülganî b. Tâlib, el-Lübâb fî şerhi'l-Kitâb, nşr. M. Muhyiddin Abdülhamîd, I-IV, Kahire: Matbaatü'l-Medenî, 1381-83/1961-63.

Molla Fenârî, Fusûlül-bedâi', nşr. M. Hasan M. Hasan İsmâil, I-II, Beyrut: Dârü’l-kütübi'l-ilmiyye, 1427/2006.

Molla Hüsrev, Dürerü'l-hükkâm, I-II, İstanbul: Şirket-i Sahâfiyye-i Osmâniyye, 1319.

Molla Hüsrev, Hâşiye ale’t-Telvîh, Sadrüşşerîa, Şerhu't-Tavzîh ale’t-Tenkīh içinde, I-III, Kahire: el-Matbaatü'l-hayriyye, 1322.

Molla Hüsrev, Mirâtüll-usûl, Muhammed b. Ahmed et-Tarsûsî, Hâşiye alâ Mirâti'l-usûl içinde, Beyrut: Dârü'l-kütübi'l-ilmiyye, 1439/2018.

Muhammed Ebû Zehre, el-Ahvâlüşş̧ahsiyye, Kahire: Dârü'l-fikri'l-Arabî, t.y.

Muhammed Ebû Zehre, Usûlüll-fikh, Kahire: Dârü'l-fikri'l-Arabî, t.y.

Mutîî, M. Bahît, Süllemül-vüsûl li-şerhi Nihâyeti’s-sûl, İsnevî, Nihâyetü's-sûl fî şerhi Minhâci'l-usûl içinde, I-IV, Beyrut: Âlemü'l-kütüb, t.y.

Müzenî, el-Muhtasar, nşr. M. Abdülkādir Şâhin, Beyrut: Dârü'l-kütübi'l-ilmiyye, 1419/1998.

Nemle, Abdülkerîm b. Ali b. Muhammed, el-Mühezzeb fî ilmi usûli’l-fikh el-mukāren, I-IV, Riyad: Mektebetür-Rüşd, 1420/1999.

Nesefî, Ebü'l-Berekât, Kenzü'd-dekāik, Sirâcüddin İbn Nüceym, en-Nehrül-fâik içinde, nşr. Ahmed İzzû İnâye, I-III, Beyrut: Dârü'l-kütübi'l-ilmiyye, 1422/2002.

Nesefî, Ebü’l-Berekât, Keş̧üll-esrâr, I-II, Beyrut: Dârü’l-kütübi'l-ilmiyye, 1406/1986.

Nevevî, Ravzatü̉t-tâlibîn, nşr. Züheyr eş-Şâvîş, I-XII, Beyrut: el-Mektebü’l-İslâmî, $1405 / 1985$.

Özen, Şükrü, “Teftâzânî”, DİA, 2011, XL, 299-308.

Pezdevî, Ebü’l-Usr, Kenzüll-vüsûl, Abdülazîz el-Buhârî, Keş̧ül-esrâr içinde, nşr. Muhammed el-Mu'tasım-Billâh el-Bağdâdî, I-IV, Beyrut: Dârü'l-kitâbi'l-Arabî, 1417/1997.

Râfiî, Abdülkerîm b. Muhammed, el-Azîz fî şerhi'l-Vecîz, nşr. Hassân b. Câsim el-Hâyis v.dğr., I-XIII, Dübey: Câizetü Dübey ed-devliyye li'l-Kur'âni'l-Kerîm, 1437/2016.

Rahbî, İbnüll-Mütefennine Ebû Abdullah Muhammed b. Ali, er-Rahbiyye fî̀ ilmi'l-ferâiz bi-Şerhi Sıbtil-Mardînî ve Hâşiyeti'l-allâme el-Bakarî, nşr. Mustafa Dîb el-Bugā, D1maşk: Dârüll-kalem, 1408/1988.

Remlî, Şemseddin, Nihâyetü'l-muhtâc, I-VIII, Beyrut: Dârü'l-fikr, 1404/1984.

Sadrüşşerîa, et-Tavzîh şerhu't-Tenkīh, nşr. M. Adnân Dervîş, I-II, Beyrut: Dârü’l-Erkām b. Ebü'l-Erkām, 1419/1998.

Secâvendî, Muhammed b. Muhammed, el-Ferâizü’s-Sirâciyye, Seyyid Şerîf el-Cürcânî, Şerhu'l-Ferâizi’s-Sirâciyye içinde, İstanbul: Dârü't-tıbâati'l-âmire, 1309.

Sekkā, Abdülmün'im Fâris, Ahkâmü'l-gāib ve’l-mefkūd fill-fikhill-İslâmî: Dirâse mukārene, Dımaşk: Dârü’n-nevâdir, 1429/2008.

Semerkandî, Alâeddin, Mîzânü̉l-usûl fî netâicil-ukūl, nşr. M. Zekî Abdülber, Devha: Vizâretü'l-evkāf ve’ş-şuûni'l-İslâmiyye, 1418/1997. 
Semerkandî, Alâeddin, Tuhfetü'l-fukahâ', nşr. M. Müntasır el-Kettânî - Vehbe ez-Zühaylî I-IV, Dımaşk: Dârü'l-fikr, t.y.

Semerkandî, Alâeddin, Tuhfetü'l-fukahâ', I-III, Beyrut: Dârü'l-kütübi'l-ilmiyye, 1405/1984.

Semerkandî, Ubeydullah b. Muhammed, Câmiu'l-usûl fî beyâni'l-kavâidi'l-Hanefiyye veşs-Sâfiiyye fî usûli'l-fikh, nşr. İsmet Garibullah Şimşek, I-II, İstanbul: TDV İSAM Yayınlar1, 1441/2020.

Serahsî, Şemsüleimme, el-Mebsût, I-XXX, Kahire: Matbaatü’s-saâde, 1324-31.

Serahsî, Şemsüleimme, el-Usûl, nşr. Ebü’l-Vefâ el-Efgānî, I-II, Haydarâbâd: Lecnetü ihyâi'l-maârifi'n-Nu'mâniyye, 1372.

Siğnâkī, el-Kâfî, nşr. Fahreddin Seyyid Muhammed Kānit, IV, Riyad: Mektebetürr-Rüşd, $1422 / 2001$.

Sübkî, Tâceddin, Cem'u'l-cevâmi', Hasan b. Muhammed el-Attâr, Hâşiyetül-Attâr alâ Cem‘i’l-cevâmi içinde, I-II, Kahire: el-Mektebetü’t-ticâriyyetü'l-kübrâ, 1358.

Sübkî, Tâceddin - Takıyyüddin es-Sübkî, el-İbhâc fî şerhi'l-Minhâc, nşr. Ahmed Cemâl ezZemzemî - Nûruddin Abdülcebbâr Sagīrî, I-VII, Dübey: Dârü'l-buhûs li'd-dirâsâti'lİslâmiyye, 1424/2004.

Şa ‘bân, Zekiyyüddin, Usûlüll-fikhil-IIslâmî, Bingazi: Menşûrâtü Câmiati Karyûnus Külliyetü'l-kānûn, 1979.

Şâfiî, el-Üm, nşr. M. Zührî en-Neccâr, I-VIII, Beyrut: Dârü'l-ma'rife, 1393/1973.

Şâşî, Ebû Ali, el-Usûl, nşr. Halîl el-Meys, Beyrut: Dârül-kitâbi'l-Arabî, 1402/1982.

Şâş̂î, Nizâmeddin, el-Usûl, nşr. M. Ekrem en-Nedvî, Beyrut: Dârü’l-garbi'l-İslâmî 2000.

Şelebî, M. Mustafa, Ahkâmü'l-mevârîs beyne'l-fikh ve'l-kānûn, Beyrut: Dârü’n-nehdati'l-Arabiyye, 1978.

Şelebî, M. Mustafa, Usûlü'l-fikhi'l-İslâmî, Beyrut: Dârü'n-nehdati'l-Arabiyye 1406/1986.

Şeybânî, Muhammed b. Hasan, el-Asl, nşr. Mehmet Boynukalın, I-XII, Beyrut: Dâru İbn Hazm, 1433/2012.

Şeyhîzâde [Dâmâd], Mecmau’l-enhur, nşr. Muhammed Hasan Talu v.dğr., I-II, İstanbul: Tereke Yayıncilık,1436/2015.

Şîrâzî, Ebû İshak, el-Mühezzeb, nşr. Muhammed ez-Zühaylî, I-VI, Dımaşk: Dârü'l-kalem -Beyrut: ed-Dârü’ş-Şâmiyye, 1412-17/1992-96.

Şîrâzî, Ebû İshak, et-Tebsıra fî usûli'l-fikh, nşr. M. Hasan Heyto, Dımaşk: Dârü’l-fikr, 1980.

Şîrâzî, Ebû İshak, et-Tenbîh, nşr. Ali M. Muavvaz - Âdil Ahmed Abdülmevcûd, Beyrut: Dârü'l-Erkam, 1418/1997.

Şîrâzî, Ebû İshak, Şerhu’l-Lüma', nşr. Abdülmecîd Türkî, I-II, Beyrut: Dârü’l-garbi’l-İslâmî, $1408 / 1988$.

Şirbînî, Abdurrahman b. Muhammed, Takrîrüşs-Şirbînî alâ Cem‘i’l-cevâmi‘ lỉl-imâm İbnis-Sübkî, Hasan b. Muhammed el-Attâr, Hâşiyetü'l-Attâr alâ Cemi'l-cevâmi' içinde, I-II, Kahire: el-Mektebetü’t-ticâriyyetüll-kübrâ, 1358.

Şirbînî, Hatîb, Muğnil-muhtâc ilâ ma'rifeti meânî elfâzill-Minhâc, nşr. Ali M. Muavvaz Âdil Ahmed Abdülmevcûd, I-VI, Beyrut: Dârü'l-kütübi'l-ilmiyye, 1427/2006.

Tahâvî, el-Muhtasar, Kahire: Matbaatü dâri'l-kitâbi'l-Arabî, 1370. 
Tarsûsî, Muhammed b. Ahmed, Hâşsiye alâ Mirâti’l-usûl, Beyrut: Dârüll-kütübi'l-ilmiyye, $1439 / 2018$.

Teftâzânî, et-Telvîh, nşr. M. Adnan Dervîş, I-II, Beyrut: Dârü’l-Erkām b. Ebü’l-Erkām, 1419/1998.

Timurtâşî, Muhammed b. Abdullah, Tenvîrül-ebsâr, İbn Âbidîn, Reddü'l-muhtâr içinde, nşr. Hüsâmeddin b. M. Sâlih el-Ferfûr, I-XVI, Dımaşk: Dârü's-sekāfe ve’t-türâs, $1421 / 2000$.

Ünalan, Abdülkerim, "İslam Hukukunda Gaibin / Mefkûdun Evlilik ve Miras Durumu (Mukayeseli Olarak)”, Dicle Üniversitesi İlahiyat Fakültesi Dergisi, 3/1 (2001): 111-148.

Üsmendî, Bezlü’n-nazar fi'l-usûl, nşr. M. Zekî Abdülber, Kahire: Mektebetü dâri’t-türâs, 1412/1992.

Zekeriyyâ el-Ensârî, Fethu'l-vehhâb: Şerhu Menhecit-tullâb, Süleyman b. Muhammed b. Ömer el-Büceyrimî, Hâşiyetü’l-Büceyrimî içinde, nşr. Abdullah Mahmûd M. Ömer, I-III, Beyrut: Dârü'l-kütübi'l-ilmiyye, 1420/2000.

Zerkeşî, Bedreddin, el-Bahrü'l-muhît, nşr. Abdüssettâr Ebû Gudde v.dğr., I-VI, Küveyt: Vizâretü'l-evkāf veş-şuûni'l-İslâmiyye, 1413/1992.

Zeydân, Abdülkerîm, el-Vecîz fî usûli'l-fikh, Bağdat: Matbaatü's-Selmân el-A'zamî, 1387/ 1967.

Zeylaî, Osman b. Ali, Tebyînüll-hakāik, I-VI, Bulak: el-Matbaatü'l-kübrâ el-emîriyye, 131315.

Zühaylî, M. Mustafa, el-Vecîz fì usûli'l-fikhi'l-İslâmî, Dımaşk: Dârü’l-hayr, 1423/2003.

Zühaylî, Vehbe, el-Fıkhüşs-Şâfî̀ el-müyesser, I-II, Dımaşk: Dârü'l-fikr, 1438/2017.

Zühaylî, Vehbe, el-Fıkhül-İslâmî ve edilletüh, I-VIII, Dımaşk: Dârü'l-fikr, 1405/1985.

Zühaylî, Vehbe, Usûlül-fikh, Trablus: Külliyyetü'd-da'veti'l-İslâmiyye, 1410/1990.

Zühaylî, Vehbe, Usûlü̉l-fikhi'l-İslâmî, I-II, Dımaşk: Dârüll-fikr, 1406/1986.

Züheyr, M. Ebü’n-Nûr, Usûlül-fikh, Kahire: el-Mektebetü'l-Ezheriyye li’t-türâs, 1412/1992. 


\section{An Oft-Repeated Fallacy in Writing and Teaching Islamic Legal Methodology and Its Significations: The Case of Mafqūd}

Once the evidence of "istiṣhāb" (presumption of continuity), a matter widely discussed within $u s \underline{u}$ l al-fiqh (the science that studies the sources of al-fiqh and the methods of deriving rulings from these sources; as well as the literature related to this science), is examined from an integrative perspective, it can be said that it is the expression of a chain of thoughts converging on the essential consideration "al-yaqīn lā yazūl bi al-shakk" (a certainty is not removed by doubt). The common aspect of this evidence echoed in Islamic jurisprudence might be verbalized as "to rule that a situation existing previously is continuing at present until the contrary is proven"; to put it succinctly, "to presume that what is remains in the same state as it was". The article does not discuss types of presumption of continuity, nor the expansions of this main principle that appears in Mecelle-i Ahkâm-ı Adliyye (article 4) and is, according to some authors of legal maxim works, one of the five universal maxims encompassing the whole of Islamic law. Instead, it draws attention to and deliberates on the significations of an oft-repeated fallacy exemplifying knowledge that has become almost axiomatic in the examination of the evidential value of "istiṣhāb al-ḥāl" (presumption of continuity of a legal status quo ante) which is generally presented as a type of presumption of continuity.

A methodological disagreement is formulated as, "according to the Hanafis, presumption of continuity is a valid proof for preserving ( $\left.d a f^{\prime}\right)$ existing rights depending on preexisting conditions, yet it is not valid for the-acquisition of new ones (ithbāt); whereas it is valid in both cases according to the Shäfi'îs". One of the salient examples of this relates to the question of a person who has moved away from his hometown and whose vital status is unknown (mafqūd): Can he inherit property, and can his property be inherited? According to the information reiterated in numerous Hanafĩ works of ușül al-fiqh, recent textbooks of uṣūl al-fiqh, as well as modern scientific publications, for both the Hanafis and the Shāfi'is, the property of the missing person -before the death of the missing person is certain or is declared by the court- cannot be divided among his heirs (presumption of continuity is a valid proof in daf ); however, the two schools hold different positions on whether the missing person can inherit the property of his relatives who died within this period before the missing person's vital status is clarified. According to the Shāfi îs, the missing person can inherit from them (presumption of continuity is a valid proof in ithbāt, too), whereas the Hanafis maintain that the missing person cannot inherit from them (presumption of continuity is not a valid proof in ithbāt).

Our investigation concludes with the opinion that the widespread knowledge in the writings and teachings of ușull al-fiqh concerning the heirship of the missing person is an "oft-repeated fallacy" and observes that this fallacy, repeated for centuries, also persists in the present day. It is also emphasized that the second part of the formula "the missing person is deemed alive in respect to his own rights and dead in respect to the rights of others", which became widespread in Hanafi works of furü $\bar{u}^{\prime}$ al-fiqh ([in short al-fiqh] the science that deals with a person's duties 
towards Allah and both dimensions of positive law, i.e. substantive law and procedural law; as well as the literature related to this science) after a certain period, is not a sound statement and might even have contributed to the intensification of the abovementioned oft-repeated fallacy.

In fact, it is observed that both Hanafĩ and Shāfi'i jurisprudents (as a matter of fact, jurisprudents of all four schools) exhibited sound reasoning ability dealing with the question of the heirship of the missing person; nearly all of them defended the opinion that the same ruling would not apply to both regular heirs and the missing person. They asserted, beginning with the probability that the missing person could be alive, that the missing person's share must be preserved/taken under protection until his status was clarified; moreover, they attached particular importance to the calculation of the highest share the missing person might receive pursuant to the present table of inheritors as required by the rulings of Islamic laws of inheritance. Therefore, there seems to be no essential disagreement among mentioned schools on the kernel of the issue. While it is stated that according to al-Shaf 'ì/the Shäfi'is the missing person while missing can be an heir to his relatives, whereas according to the Hanafis he cannot be, our investigations make it possible to claim that the origin of this statement is a statement in al-Dabūsī's book titled Taqwìm al-adilla. However, his statement contains the expression "according to one/some of the Shäfi'i scholars" and not "according to al-Shaf 'î" nor "according to the Shäfi'îs". Nonetheless, it is observed that after a certain period, some Hanafī works of ușūl al-fiqh began to present this fallacious example to explain the abovementioned methodological disagreement.

The article classifies prominent Hanafī works on uṣūl al-fiqh after al-Sarakhsī under three categories: a) Those that preferred not to use the matter of heirship of the missing person as an example, b) those that used this example only to explain the Hanafi position, and c) those that gave space to this example in order to show both the Hanafì and Shāfi'i approaches comparatively.

Examining the Hanafî literature on $f u r \bar{u}^{\prime}$ al-fiqh, it is observed that al-Shaybānī's (d. 189/805) narrative about this issue in al-Așl, the primary resource of the school, has not been generally reflected afterwards in its entirety. The statement, "the missing person cannot be heir to anybody who died while he was missing" that appeared first in al-Qudūrîs (d. 428/1037) al-Mukhtașar, has been effective in reinforcing of mentioned fallacy (that is, "the missing person could inherit from one's relatives according to the Shäfi'is, whereas the missing person could not be an heir according to the Hanafis") which is clearly reiterated in some later Hanafi books on $u s \underline{u} l$ al-fiqh. In addition to that, the widely circulated formula in Hanafi works on furü' al-fiqh that "the missing person (...) is deemed dead in respect to others' rights" also contributed to the circulation of this fallacy.

Some authors, taking notice of that the statements regarding the missing person -he cannot be an heir to anybody and is deemed dead in respect to others' rightsare inconsistent with the ruling applied in this matter, provided reasonable explanations for this inconsistency. However, recently written textbooks and numerous research texts concerning the issue have failed to take notice of these explanations 
and continue to use this formula as a symbolic example of the methodological disagreement among the Hanafìs and the Shāfi'îs.

As far as we can see, Shāfi'ì works on uṣūl al-fiqh and furū' al-fiqh neither state that the missing person can be an heir, nor that there exists a methodological disagreement between themselves and the Hanafis. On the contrary, principal Hanafì and Shāfíì sources on furū' al-fiqh (particularly al-Shaybānī’s [d. 189/805] al-Așl) determine that "the missing person is not known to be alive or dead" and his shares is taken under protection until his status is clarified", which means that the two schools do not differ from each other in their approaches. Although this is obvious, it is observed that a fictitious methodological disagreement has been produced as if there was a disagreement in fur $\bar{u}^{`}$ al-fiqh, which has led to the oft-repeated fallacy: "The missing person cannot be an heir according to the Hanafîs but can be one according to the Shäfi îs". This fallacy has survived for centuries and still persists today.

Conversely, it is established that numerous scholars of $u s \underline{u} l$ al-fiqh refrain from repeating this example. Interestingly, Ibn Nujaym, who repeats this fallacy in his various works, cites in his The Treatise on Istișhāb, Ibn Humām's statement -the one he follows- "the missing person is an heir according to Shäfi'ìs, but not according to us", and then he states that this is a "sahw" (an overlooked mistake). Afterwards Ibn Nujaym provides the explanation, "the ruling transmitted by both schools is that the missing person's share will be preserved". Still, among those who are cognizant of this warning, which could fulfill a significant function in correcting the oft-repeated fallacy in question, none of them -as far as we know- exhibited a particular interest in it or attempted to disrupt the faulty knowledge transfer with a critical perspective in the light of the abovementioned analysis.

The article ends by dealing with some problems of method suggested by the above-mentioned findings and their negative impacts on the development of legal thought. It draws attention especially to the disadvantages of regarding established knowledge reiterated in the works of usuul al-figh as data distilled through centuries without exhibiting any hesitation about their reliability and of neglecting works of furü' al-fiqh. It points out that the rulings of furü al-fiqh appear in these works merely as examples, that is to say, the intention here is not to teach the ruling of $f u r \bar{u}^{\prime}$ al-fiqh, but to explain the relevant methodological principle. Meanwhile, it shows that numerous authors, probably under the influence of the repetition for centuries, cite those passages of works where presumption of continuity and the missing person are mentioned and presume that this knowledge is contained in the relevant passages, even though the supposed knowledge does not exist in the works of $u s ̦ \bar{u} l$ al-fiqh they cite. In addition, the article underlines the significance of a critical approach and conceptual refinement in writing and teaching al-fiqh, and the necessity of encouraging analytical thought and prioritizing theories of al-fiqh instead of making students memorize rulings of legal events.

Keywords: mafqūd, istiṣhāb, daf', ithbāt, inheritance, heir, inheritor, uṣūl al-fiqh, furū'al-fiqh. 